The Ethics of Recognition in International Relations: A Global and Cross-Cultural Perspective

\author{
By \\ Mahmoud Masaeli
}

A thesis submitted to the Faculty of Graduate and Postdoctoral Affairs in partial fulfillment of the requirements for the degree of

Doctor of Philosophy

in

Political Science

Carleton University

Ottawa, Ontario

(C) 2010

Mahmoud Masaeli 
Library and Archives Canada

Published Heritage Branch

395 Wellington Street Ottawa ON K1A ON4 Canada
Bibliothèque et

Archives Canada

Direction du

Patrimoine de l'édition

395 , rue Wellington

Ottawa ON K1A 0N4

Canada
Your file Votre référence ISBN: 978-0-494-79627-6 Our file Notre référence ISBN: 978-0-494-79627-6
NOTICE:

The author has granted a nonexclusive license allowing Library and Archives Canada to reproduce, publish, archive, preserve, conserve, communicate to the public by telecommunication or on the Internet, loan, distribute and sell theses worldwide, for commercial or noncommercial purposes, in microform, paper, electronic and/or any other formats.

The author retains copyright ownership and moral rights in this thesis. Neither the thesis nor substantial extracts from it may be printed or otherwise reproduced without the author's permission.
AVIS:

L'auteur a accordé une licence non exclusive permettant à la Bibliothèque et Archives Canada de reproduire, publier, archiver, sauvegarder, conserver, transmettre au public par télécommunication ou par l'Internet, prêter, distribuer et vendre des thèses partout dans le monde, à des fins commerciales ou autres, sur support microforme, papier, électronique et/ou autres formats.

L'auteur conserve la propriété du droit d'auteur et des droits moraux qui protège cette thèse. $\mathrm{Ni}$ la thèse ni des extraits substantiels de celle-ci ne doivent être imprimés ou autrement reproduits sans son autorisation.
In compliance with the Canadian Privacy Act some supporting forms may have been removed from this thesis.

While these forms may be included in the document page count, their removal does not represent any loss of content from the thesis.
Conformément à la loi canadienne sur la protection de la vie privée, quelques formulaires secondaires ont été enlevés de cette thèse.

Bien que ces formulaires aient inclus dans la pagination, il n'y aura aucun contenu manquant. 


\title{
The Ethics of Recognition in International Relations A Global and Cross-Cultural Perspective
}

\begin{abstract}
Recognition is a concept that has recently been employed by political thinkers in the analysis and addressing of the growing demand for recognition by those who have been marked racially, sexually, culturally, and ethnically as different. Such a demand -has been launched in a number of strands in contemporary politics both in domestic and international spheres. Central to the demand - the struggle - for recognition is the idea that unwillingness to recognize the equal worth of different others give way to exclusion and oppression, and consequently to injustice. Recognition is not only a vital need for formation of the sense of personhood, but it is also a necessary condition for a just life-world: recognition as justice. In other words, recognition, in its fullest sense, is both an authentic way of expressing the sense of nationhood/statehood, and an operative concept in the liberation from patterns of social devaluation, exclusion, and invisible forms of repression.
\end{abstract}

The most relevant to the conception of recognition is the impacts of the process of globalization on enhancing the scope of the public sphere, and more specifically, providing opportunity for the marginalized and silenced forces to become conscious of their unequal share in the life-world. This consciousness motivates the struggle for recognition through democratization of the public sphere both internally and internationally. Indeed, in the globalizing world, where a common destiny is being experienced, the struggle for recognition is further heated by implication, and theoretically, advances the possibility of a more effective participation in global governance.

In light of these observations, the argument must be advanced that the full recognition of nations/states must be considered as the most basic expression of their selfhood/nationhood. By addressing the increasing demand for a more inclusive international relation, theorizing of recognition also gives urgency to the removal of the patterns of exclusion and oppression.

Theorizing recognition involves an examination of the historical backgrounds in which the different senses of nationhood/statehood have been developed. Such differences must not become the subject of the already dominant arrangements in the life-world if a democratically more transparent and just international public sphere must be achieved. In other words, by acknowledging such differences, the theory of recognition has potentials to accommodate cross cultural/ethical divisions and bring disparate voices together in a more participatory and inclusive manner. 


\section{Acknowledgment}

I owe completion of this dissertation to the following professors, whose comments and recommendations prevented me from falling down in intellectual pitfalls

I express my thanks to them (In the alphabetical order):

1. Rajaee, Farhang

2. Robinson, Fiona

3. Schmidt, Brian 
Table of the Contents:

Abstract

Acknowledgment

$\begin{array}{ll}\text { Introduction } & 1\end{array}$

Scholarly Background $\quad 11$

The Plan of Research $\quad 15$

$\begin{array}{ll}\text { Chapter 1: Globalization and Recognition } & 18\end{array}$

The Globalization Debate 24

Transformationalist Thesis and the Issue of Recognition 26

Glocalization: A Different Transformative Thesis 38

Globalization and the Backdrop of Reflexive Modernity $\quad 45$

Globalization: Exclusion or Inclusion $\quad 50$

Chapter 2: Difference and Recognition in International Political Theory 59

Part One: The Question of Difference in Liberal Normative Tradition 60

Part Two: Acknowledgment of Difference in Alternative Approaches 74

Liberal-Communitarian Debate and Questions of Difference $\quad 79$

Difference in Post-Foundationalist Perspectives 86

Critical International Relations Theory and Appreciation of

Difference

95

Chapter 3: Beyond Mere Respect: Towards the Politics of Recognition 110

Theory of Recognition 113

The Politics of Recognition of Difference: Taylor's Account 128

Dialogue over Recognition of Identity 139

A Recognition-based Approach to Justice 146

Recognition and Socio-Political Solidarity 156

Chapter 4: Toward an Ethics of Recognition in International Relations 160

Dilemma of Non-Recognition and Power 165

Recognition as Justice $\quad 174$

Civil Society Helping Recognition as Justice $\quad 179$

Recognition, Justice, and Solidarity 193

$\begin{array}{ll}\text { Conclusion } & 196\end{array}$

$\begin{array}{ll}\text { Bibliography } & 208\end{array}$ 


\section{Introduction}

The importance of recognition is now universally acknowledged in one form or another; on an intimate plane, we are aware of how identity can be formed or malformed through the course of our contact with significant others. On the social plane, we have a continuing politics of recognition of equal recognition. Both planes have been shaped by the growing ideal of authenticity, and recognition plays an essential role in the culture that has arisen around this ideal.

Charles Taylor, "The Politics of Recognition", p. 232.

This thesis is concerned with the ethics of recognition in International Relations. ${ }^{1}$ I use recognition, here, to convey something more substantive than conventional/legal usage of the concept prevalent in both International Relations and International Law. I propose substantive recognition instead that is a meaningful acknowledgment of all voices that are either ignored or suppressed and still or are not articulated. Therefore, my use of recognition differs from the practice of "constitutive recognition" of statehood through which political entities receive international rights and obligations when they are recognized by other states as states. It is also different from "declaratory recognition" which considers autonomy and independence as necessary conditions for the actualization of the state. In the declaratory account of recognition i.e., the realist view, statehood depends on the active application of authority over a given territory. In the liberal account of recognition, statehood depends not only on the ability to control actors and activities within national boundaries, but also the ability to display it beyond its borders. Indeed, the latter demands the state's ability to cope with internationally generated problems and issues

\footnotetext{
${ }^{1}$ In writing this thesis I have been inspired by Charles Taylor's account of recognition of difference. See Charles Taylor, "The Politics of Recognition," in Philosophical Arguments (Cambridge, Harvard University Press. 1977).
} 
effectively. In both cases, recognition is a matter of benefit calculation via the lenses of legal considerations, since both perspectives understand statehood in terms of the principle of sovereignty.

My purpose in this dissertation is to go beyond the narrowness of both liberalism and realism and explore how those who have been misrecognized or non-recognized by these dominant discourses of recognition, and consequently have been excluded from the discourse of international life, might be acknowledged and counted. In this sense recognition is not a legal framework but a substantive institution facilitating the active participation of all states on equal terms with all other players. In the practice of current international law, although states of different social and constitutional systems might be legally recognized what is lacking in international relations is a meaningful sense of membership. That is to say, merely counted in the roster of players in the game of international relations does not mean that a state is an active member of the "international $w e$ " because the current exercise of recognition, in its best normative execution, still depends on the sovereign will of the more powerful states, who in practice decide the actual role and effectiveness in international relations. ${ }^{2}$

Looking at the existing practice of recognition from another angle, we can argue that the current practice of recognition, indeed, reflects the politicization of the manners of state's actualization for calculative purposes of different kinds and degrees. Accordingly, in the real world, the current international we is marked by an unfortunate domination/subordination - sovereignty/obedience - a model which operates based on an unjust hierarchical political order. In this tragic model, states are politically recognized

\footnotetext{
${ }^{2}$ Robert R. Williams, Hegel's Ethics of Recognition (Berkeley: University of California Press, 1979), p. 357.
} 
with different degrees, depending on their ability to respond the requirements of the current international system. There are the principal - mostly the Northern - members, the allied trusted partners such as Saudi Arabia, Egypt, and Jordan, the new competitors such as China, India, and Brazil, the dependent states such as Afghanistan and Honduras, who are obedient to the will of the principal members, and finally there are - the outlaws - others such as Libya, and Cambodia, and Iran, who have been exiled into eclipse.

The failure of the current practice of recognition in facilitating effective participation poses the questions of how an alternative account of recognition may help to open the gates of the international we for true membership, and how such alternative might help a more participatory and, consequently a more just world. It is in this sense that recognition becomes the basis for a theory of justice.

The ethics of recognition ascribes a kind of duty to all states, notably the superior states, to recognize equality and participatory rights of others in the articulation of a more just discourse of the life-world. This is a perfect duty since it derives from the categorical reason expressing the equality of all members of the international we states articulated in many of the agreed upon universally agreed upon legal instruments among them the United Nations Charter ${ }^{3}$. This duty attributes an undeniable triple task to states, especially those of liberal states. First, they must avoid self-centeredness and any account of unwillingness to recognize the equality and participatory rights of others in the discourse of the life-world. Second, they ought to advance democratic values and participatory parity rules in the world. Third, they are under a moral obligation to enlighten others, being either dominant or subordinate, to understand the central

\footnotetext{
${ }^{3}$ See the United Nations Charter, Preamble, paragraph two confirming the equality of all nations large and small, and article 2, paragraph 1 acknowledging rigorously the equality of all members of the United Nations.
} 
importance of recognition of equality for the current world. This perfect duty is the point of departure of the ethics of recognition from the legal account of recognition since it is sensitive toward the due recognition of different others. Therefore, although I ground the idea of the ethics of recognition based on the Westphalian format of the world, I argue that the mere legal recognition fails to truly acknowledge the equal worth of the potential participants in the discourse of the life-world.

It must be noted that, as the fundamental terms of membership in a culturally embedded life-world, recognition is primarily an ethical conception itself. Because it is through recognition that the nationhood/statehood ${ }^{4}$ is mediated, the consciousness of rights and obligations are actualized, and the public sphere is formed. ${ }^{5}$ Therefore, misrecognition or nonrecognition inflicts harm and distorts forms of life, and ultimately gives way to exclusion and oppression. It is here that I can draw again on the central importance of recognition as the basis of justice and argue that a willingness to engage in mutual recognition reflects a belief in equal worth of all members of the international we, while its absence will result in inequality and injustice.

It follows that willingness to recognize the equal worth of different others would be a sound source of an alternative approach to liberal concept of justice. Recognition as justice differs from redistributive justice. Rather, as will be discussed in chapter four of

\footnotetext{
${ }^{4}$ I use the nationhood/statehood to stress a notion of the state which is defined in relation to people who have been hold together and formed a kind of political community. It is a kind of state-in-relation-to-people. Therefore, I eschew reference to any conception of the autonomy of state abstracted from people's sovereignty - political community - to express democratic ways of the formation of the statehood. Democratic ways of the formation of the statehood being either Held's communities of fate, or Rawls' overlapping consensus, Habermas' communicative approach, or Taylor's dialogical model connote the importance of people beyond the mere mechanical - and mostly Hobbesian - state's actualization.

${ }^{5}$ I borrowed this term from Hegel to clarify my reading of embedded life-world in which human life is crossculturally acknowledged. See: Georg H. W. Hegel, Philosophy of Right (Oxford: Clarendon Press, 1949), part three, Para. 142.
} 
this dissertation, it is more concerned with eliminating the cause(s) of humiliation, disrespect, and exclusion. For this reason, recognition seeks to provide just condition for equal participation in the - internal or international - public sphere. I suggest that the absence of this condition is one of the most important causes of social cleavage, political fragmentation, and conflict. The existence of injustice has its roots in the practice of misrecognition/non-recognition thereby admitting inequality which is itself a deliberate source of conflicts. I argue, then, that causes of injustice and conflicts are not to be found solely in power-seeking character of state or in the anarchical system, but primarily in the unwillingness of the more powerful states to recognize the equal worth of different others. In other words, the causes of injustice and conflicts must be looked for in the recognition/nonrecognition dilemma in light of which the conception of the power in International Relations must be rethought.

The process of globalization is at the center of my account of recognition because it enhances the scope of a public sphere in which dialogue for recognition is more and more facilitated. Broadly observed, the centrifugal forces of globalization can potentially polarize the world due to the opportunity which has been provided for the marginalized forces to come to the forefront of the decentralized world and struggle for recognition of their equality. ${ }^{6}$ It might also be seen as a glocalizing process crossing the global-local nexus. $^{7}$ The process of globalization might be considered in any of these senses; all point to the fact is that our world is deeply being transformed. The process of globalization has provided opportunities to reformulate and reshape the life-world and its political

\footnotetext{
${ }^{6}$ For these two accounts of globalization see: Fred R. Dallmayr, Achieving our World: Toward a Global and Plural Democracy (Lanham, Maryland: Rowman \& Littlefield Publishers, Inc., 2001).

${ }^{7}$ For this account of globalization see: Ronald Robertson, Globalization: Social Theory and Global Culture (London: Sage, 1992).
} 
implications. One of the most crucial - and most relevant - implications is the weakening of the European system of sovereign states, which had tended to marginalize and even exclude different others from the life-world ${ }^{8}$. As Giddens argues, in a world, where "information and images are routinely transmitted across the globe, we are all regularly in contact with others who think differently, and live differently, from ourselves". ${ }^{9}$ The new voices are often being heard from parts of the world pressing the urgent demand for a redefinition of the international we. In these deeply complex circumstances, 1 argue that traditional forms of recognition fail to address the globalizing world of transformations and its implications. What is required is a new ethics of recognition that addresses emerging demand for an effective membership in the international we. The new ethics of recognition should keep in balance the contemporary life-world and consequently prevents "radical forms of (centrifugal or centripetal) world alienation".10

Having taken this theme of investigation into account, my plan is to analyze and answer the following research questions: First, How might an ethics of recognition - which has been articulated by a number of theorists for the domestic context - be developed for the context of global politics? Second, how might this ethics of recognition effectively address the demands of global justice?

In analyzing and answering these questions, I begin with the assumption that the current practice of recognition of states is inadequate in the conditions of globalization. I

\footnotetext{
${ }^{8} \mathrm{I}$ assume that the European system of sovereign states is transforming as a result of the emergence of the forces of change. Following Richard Falk, this erosion takes place in two orientations. From above, the growing power of corporate capital reflected in dominance of multinational enterprises and global finance affect the compassionate state. From below, the civic globalization challenges the traditional pattern of state sovereignty. For details of this account see: Richard Falk, The Declining World Order: American's Imperial Geopolitics (New York: Routledge: 1994); and Richard Falk, "Global Civil Society: Perspectives, Initiatives, and Movements," Oxford Development Studies 26 (1998): 99-110.

${ }^{9}$ Anthony Giddens, Runaway World (New York: Routledge, 2000), pp. 4-5.

${ }^{10}$ Dallmayr, Achieving our World, p. xiii.
} 
argue, then, in favour of an ethics of recognition advancing an account of duty to struggle for a more participatory and just world. This ethics acknowledges the equality and participatory rights of participants via a vision of dialogue as a fully-fledged engagement for mutual learning and understanding from which a more just world may emerge. By relying particularly on the institutions of global civil society, I also argue that recognition of this nature can potentially lead to a more reliable global solidarity.

The theory of recognition advanced here suggests the possibility of achieving a more inclusive public sphere and a subjective willingness to recognize different others, and consequently surmount the limitations of the exclusivist policies and practices in the existing international system. This aspiration for a more inclusionary vision has already found voices in a number of different projects revolving around the idea of dialogue from across the globe. One of the most important of these projects is The Alliance of Civilizations initiated by the President of Spain, José Luis Rodríguez Zapatero and the Turkish Prime Minister, Recep Tayyip Erdoğan at the 59th General Assembly of the United Nations in 2005. Examples are not limited to the summit of the head of governments. Many civil society voices such as Foundation for "Dialogue among Civilizations", "Centre for Dialogue", "East-West Dialogue Group", and "Institute for Interreligious Dialogue" demand dialogue and cooperation as well.

In this respect, the process of globalization, as will be discussed in the first chapter, strengthens the bridging capacity of theory of recognition since it provides the marginalized voices with opportunity to come to the fore. In addition, in the globalizing world the pressures of the civil society from inside and transnational civil society form outside have the potential to motivate the more powerful and reluctant actors to enter 
willfully into dialogue over mutual recognition with different others and even proceeding certain re-adjustment in the unjust world around a more inclusionary structures such as observing the participatory rights of others in the process of decision making in the institutions of global governance. The process leading to this re-adjusted world would be an emancipatory discourse envisioning a rooted cosmopolitan world in which the conflictual forces are sublimated into dialogue and mutual recognition, contradictory visions are raised into a reconciliatory overlapping consensus, and the sources of disagreement and conflict eventually turn into solidarity. The "international we" has the potential to establish a new manner of holding transnational power systems opening up to inclusion and participation of its members. This ideal international we can potentially bring about more openness for the politics of inclusion and effective participation with minimum cultural, rational, geographical, and national restrictions.

The central objective of this thesis is the development of an ethics of recognition beyond the existing legal one. I start with the Westphalian model and acknowledge that the state is still the central actor in international relations. This is as far as my agreement with the realist and the liberal accounts of recognition stands. These perspectives of recognition, to different degrees, follow their own account of benefit calculation and discount the need for substantive recognition of others. In contrast, I am arguing for an ethics of recognition which is grounded on the imperative of duty. Emphasizing this imperative is my point of departure from both realism and liberalism. It must be noted that in developing this account of ethical recognition, I advance the idea that statehood is tied expressly to democratic legitimacy both internally and internationally. Therefore, only the states which represent the will of their own citizens must be recognized as true 
member of the international we. Democratic criteria determine the threshold of recognition and participation. What results from this account of recognition would be a possibility of replacing the politics of misrecognition and non-recognition with a more participatory and, hence, just world. Theoretically speaking, in this model there is no chance for non-democratic and oppressive states to become active members of the international we.

In the globalizing world, the legal framework of recognition fails to address effectively the growing struggles for recognition and active participation in the international we; hence, there is a vital need to move toward an ethical theorizing of recognition. I am not, therefore, going to advance a fully-fledged blueprint for the actualization of the ethics of recognition. I will engage in the intellectual background and analysis of the conception of recognition to the extent that is required for articulation of this account of recognition. However, since the subject of theory is mainly a reflection of the world surrounding us composed of real entities, mainly sovereign states, I will refer to the 'real world' to support my argument. Indeed, while the focus of the thesis is on ethics of recognition, the accurateness of such account of recognition requires an examination of changes and transformations of the real world especially the globalizing world. Furthermore, my plan is to analyze and understand the complexity of the prevailing misrecognition/non-recognition practices as the main cause of the unjust world by the help of practical reason. It is practical reason that motivates a move away from procedural reason, and political incentives toward our duty to advance a more participatory just world. 
Here is that once again I depart substantively from the instrumental and procedural accounts of reason employed by realism and liberalism to indicate the imperative of the perfect duty to recognize. Indeed, in the case of the contrast between the two accounts of rationality amounting to two different accounts of recognition, i.e. legal recognition and the ethical one, I argue, we must surrender our claim to the latter necessarily because it springs from our perfect duty as free agents. I do believe in liberal conception of duty to advance democratic participation, and particularly recognizing different others. But my interpretation of duty is not the imperfect duty springing from procedural and instrumental reason accomplished via sympathetic or altruistic disposition toward others. Rather, it is a perfect duty commanding by practical reason to recognize.

Finally, I adopt a critical constructivism as the most appropriate theoretical approach in analyzing and constructing of the new inclusionary international we. In light of the above observations, constructivism, in the sense which is used here, means the use of practical, or according to Taylor substantive, reason to solve problems of the existing world. That is to say, ethics of recognition is constructed as a response to the unjust world based on the command of duty. The very command of reason urges us to move from legal recognition and construct an account of recognition that can potentially eradicate or substantively reduce injustice. Since this account of recognition is determined by the agent i.e. the willful action of the persons, our intellectual way to constructivism is further paved. Accordingly, practical reason as the motive behind constructivism moves us away from procedural and instrumental reason. Indeed, it is through reflecting on problem of the unjust world caused by misrecognition or nonrecognition that can arrive at the 
categorical imperative of the perfect duty to recognize. ${ }^{11}$ This approach, which guides my attempt to transgress disciplinary boundaries, will be evident throughout this dissertation.

\section{Scholarly Background}

The ethics of recognition has often been overlooked in theories of International Relations because of two reasons. One is the prevalence of legal recognition and the other one is the overriding emphasis on scientific and positivist foundations within dominant theoretical approaches. Having discussed the legal use of recognition, I am going to look briefly at the latter. Committed to a unified view of science and the adoption of methodologies of the natural sciences to explain the social world, positivism has dominated the discipline at least from the second half of the twenteeth century onward. Ontologically speaking, this approach views international relations through an atomistic lens in which states are the only major actors. These two features of the dominant approaches have acounted for the exclusion of reflexive self-inquiry of knowledge construction from theories of International Relations. In addition, scientism and positivist methodology have often contributed to the creation of parsimounious and simplistic perspectives which cannot produce an appropriate theoretical framework for understanding the complexity of international relations. More importantly, it has abstracted ethical reflection from politics and prompted understanding of the real world through the lens of an instrumentalist account of rationality which is alien to the moral world.

\footnotetext{
${ }^{11}$ Christine Korsgaard, The Constitution of Agency: Essays on Practical Reason and Moral Psychology (pp. 321322 .
} 
From the 1980s, inadequacy in understanding and addressing the cultural and identity differences among nations has brought the assumptions of mainstream theory severe criticism. Along with this criticism,communitarian thinkers have charged liberal normative theories of justice with ignoring ignorant identity question. Lack of due attention to the impact of globalization on the life-world in the areas of culture, environment, poverty, and many other ethical considerations has made liberal normative theory more questionable. It is not surprising, then, that the discipline of International Relations has recently witnessrd the emerging critical theories that challenge the narrowness of both the mainstream and liberal normative theory. However, criticism is not restricted to critical approaches. Within liberal tradition, there has also emerged challenging trends aimed at addressing new questions of culture and identity. Although not deeply engaged in ethics, and hence, appreciation of the conception of recognition, liberal thinkers such as John Rawls and Charles Beitz have tried to shed some light upon the urgent questions of identity in world politics. This attempt has been caused in part by the emergence of critical accounts on the question of 'otherness' as an eventual threat to dominant theory and, partly by the challenge of globalization for the procedural solutions offered by neo-liberalism for political and economic aspects of the life-world. Alternative theories have disregarded the assumption that the existing differences must be recognized in order to give a full-fledged response to the struggle for equal recognition, and through which demand a more just life-world.

But, in political theory the conception of recognition becomes the culmination of debates addressing the notion of identity in the recent past. Inherited mostly from a Hegelian account of mutual recognition and influenced by Rousseau and Herder, the 
contemporary theorists of recognition promote this critical conception in political theory and ethics. ${ }^{12}$ Spanning from the critical theory of Axel Honneth to the feminist vision of Nancy Fraser and Iris Young, and from the postmodern/post-structuralism of Judith Butler, William Connolly, Chantal Mouffe, and Stuart Hall to the hermeneutics of HansGeorg Gadamer and Charles Taylor, theorists of recognition have advanced a variety of challenging accounts aiming to address the question of difference. What brings these disparities in theorizing of recognition together is a rally against the narrowness of instrumental rationalism and liberalism. Apparently, this extensive range of theories of recognition directs an objection against the exclusiveness of the dominant portrait of identity and citizenship. However, liberalism is the major target because in this vision individuals are accorded the same status without discrimination; hence any account of identity difference and cultural distinctiveness is ignored and excluded from political discourse. Therefore, contemporary theorists of recognition have placed the conception of recognition at the forefront of the current political and social insights. The purpose of the wide range of theories on recognition is to analyze the question of 'who we are' put forward by contemporary identity and social movements. Although it is not precisely possible to determine the moment the question entered contemporary political thought, I would draw on the tight connection between the emerging interests in recognition and the fundamental changes that took place in the socio-political condition of the Post-Cold War era as my starting point. I assume that from this time identity movements penetrated in almost all corners of the world in response to which theorists of recognition offered

\footnotetext{
${ }^{12}$ For example, Charles Taylor's account of recognition is deeply influenced by Rousseau and Herder. This influence allows him to give an account of recognition that can potentially be extended to the recognition of national differences in the context of international relations.
} 
their own accounts. ${ }^{13}$ They raised objection to the dominant exclusionary political discourse motivating contemporary philosophers to respond. ${ }^{14}$

It is not surprising, therefore, that philosophical accounts of recognition came about to diagnose - especially in the case of Taylor - and cure - in the case of Honneth and Fraser - the emerging political upheavals and socio-cultural malaises of the Post Cold War era, among them the ethnic cleansings, civil wars, genocidal atrocities, and sweeping anti-globalization and social and identity movements in almost all corners of the world. At least in this sense, philosophy could not remain a pure academic field of knowledge; rather it had to focus on ethical concerns and on finding ways of resolving the dramatic crisis of the Post-Cold War condition. Furthermore, philosophical reflections should have come to be the essential feature of analysis of the emerging transnational civil society. From such a perspective, the analysis of difference and whether and how, to recognize the new voices became a pressing need in understanding the emerging life-world. Simply put, globalization highlighted such a need to address the struggle for recognition of difference. ${ }^{15}$ This lack of sufficient attention to the importance of recognition as an ethical value and a policy imperative in the field of International Relations constitutes the chief motive behind the present project.

\footnotetext{
${ }^{13}$ The evidences for this claim are: Charles Taylor's Politics of Recognition was published in 1995; Axel Honneth's Struggle for Recognition: The Moral Grammar of Social Conflicts in 1995; Nancy Fraser's From Redistribution to Recognition? Dilemmas of Justice in a 'Post-Socialist' Age in 1998; Paul Ricoeur's Oneself as Another in 1992; Judith Butler's Gender Trouble in 1990 and Excitable Speech: A Politics of the Performative in 1997; William Connolly's Identity/Difference in 1991; and Chantal Mouffe's Dimensions of Radical Democracy: Pluralism, Citizenship, Community in 1992.

${ }^{14}$ Robert R. Williams, Recognition: Fichte and Hegel on the Other (New York: State University of New York, 1992), pp. 1-2.

${ }^{15}$ Scott Lash and Mike Featherstone ed., Recognition and Difference: Politics, Identity, Multiculturalism, (London, SAGE Publications Ltd., 2002).
} 


\section{The Plan of Research}

I will organize my findings into four chapters. The first chapter is an attempt to depict how, and why, the notion of recognition has become a heated topic in the current life-world. For this aim, I will describe two crucial developments in contemporary international relations. The first one is the political changes resulting from or further fuelled by the process of globalization and reflected in the emerging identity/difference movements. The second is the philosophical developments aimed at addressing the implications of the globalizing world. By shedding analytical light upon the impacts of globalization on the life-word, I will argue that the process of globalization certainly impacts social formation and relations, and the narration of identity. For this purpose, I follow three categories of interpretation of globalization including David Held's transformationalist thesis, ${ }^{16}$ Ronald Robertson's glocalization thesis, ${ }^{17}$ and globalization in the backdrop of reflexive modernity. ${ }^{18}$ This last interpretation allows me to orient my argument around the point that the process of globalization provides an opportunity to negate the negation of the ethics of liberation. Although all these interpretations are analyzed in an interwoven manner, the thrust of my analysis aims at the ethics of liberation of excluded identities and the ethical challenges of globalization.

Having built an analysis of the process of globalization, the second chapter demonstrates the failure of liberal normative theory to address the demands of identity/difference movements for recognition. To achieve this goal, the chapter begins

\footnotetext{
${ }^{16}$ David Held, Anthony McGrew, David Goldblatt, and Jonathan Perraton, Global Transformations: Politics, Economics and Culture (Stanford, Stanford University Press, 1999).

${ }^{17}$ Ronal Robertson, Globalization: Social Theory and Global Culture (London: SAGE Publications, 1992).

${ }^{18}$ Ulrich Beck, Anthony Giddens, and Scott Lash, Reflexive Modernization: Politics, Tradition and Aesthetic in the Modern Social Order (Stanford, Stan ford University Press, 1994).
} 
with an analysis of Rawls' account of justice. I will argue that his liberal vision starting from $A$ Theory of Justice, continuing through the constitutional consensus of Political Liberalism and ending in his developmental communitarian account in The Law of Peoples cannot adequately respond to emerging demands for recognition. This examination especially allows me to show that The Law of Peoples cannot be the chief medium in addressing the demands for recognition of differences in the international arena and, therefore, fails to achieve a convincing theory of justice. The rest of the chapter will contain an analysis of alternative theories addressing questions of difference. I will conclude the chapter with the idea that all attempts made by either Rawls or alternative theorists more or less acknowledge the existence of differences as an underlying factor in the analysis of the life-world. However, I claim that all of them fail effectively to offer the politics of recognition of difference as a response to the widespread demands for recognition, and by this failure, they leave the substantive questions raised by identity movements about the inadequacy existing distributive justice in the world unanswered.

The third chapter, therefore, is an attempt to analyze and respond to the struggle for recognition from a different perspective. I will argue that Charles Taylor's account of recognition is the most appropriate framework for this purpose. Although I rely on his "Politics of Recognition", I will consult his wide-ranging works, among them the Sources of the Self: Making of Modern Identity, in order to advance the thesis that dialogue is the prerequisite in the construction and definition of the selfhood. I will insist that the politics of recognition of difference diagnoses the cultural/identity malaises of the globalizing world, and hence steers societies - especially those that are marked by multi-vocal voices - toward a more reliable social solidarity. The chief focus in all of these lines of arguments 
is that misrecognition and/or non-recognition results in oppression and hence in injustice.

The fourth chapter, which contains the key theoretical contribution of this thesis, will be an attempt to formulate my notion of the ethics of recognition in international relations. I transpose Taylor's account of recognition in the field of International Relations and argue that the mainstream legal approach to recognition fails to do justice to national distinctiveness. More powerful states are not disposed to recognize different others politically; indeed they often deny, and much worse, oppress different others. From this perspective, non-recognition will be interpreted as oppression, and hence a blunt manifestation of hegemony by more powerful states. Accordingly, the unjust world of exclusion and oppression necessitates a substantive re-formulation of the question of 'who we are' and 'where we are standing' in relation to others in a global scale. I will draw on the conception of transnational civil society to formulate an account of political recognition and a basis for articulation of a new theory of global justice. 


\section{Chapter 1}

\section{Globalization and Recognition}

In these circumstances, a new categorical identity can offer people something very precarious: not only a direction, an orientation, but also a sense of (collective) agency. We are no longer just to suffer a sense of helplessness before dimly understood global forces, but we are to be mobilized against named and identified ills.

Charles Taylor,

The Sources of Violence, p. 32

As the multi-causal and multi-dimensional process of globalization is steadily crossing traditional national boundaries, many socio-political structures are undergoing enormous transformations. These transformations challenge the modern organization of social relations and, by implication, notions of political identity and the nationhood. These notions have been portrayed in light of the modern state, which has defined itself as the dominant political organization within demarcated boundaries. ${ }^{19}$ In light of these transformations, territorialism and territorial identities in International Relations have become questionable. Accordingly, social relations and interactions remain less dependent on a simultaneous physical presence within a specific location. Rather, the relationship between distant others has been facilitated; something that weakens the importance of face-to-face interaction. Indeed, globalization signals experiencing the world as a single place. ${ }^{20}$ In this world, as Ronald Robertson argues, humankind is either possibly carried forward toward a kind of global destiny - a kind of cosmopolis - or vice versa, toward newly emerging global fault lines of fragmentation and confrontation.

${ }^{19}$ This conception of the state is admitted by Anthony Giddens. See: Anthony Giddens, The Nation-State and Violence: Volume Two of A Contemporary Critique of Historical Materialism (Berkeley: University of California Press, 1989), pp. 17-22.

${ }^{20}$ Ronal Robertson, Globalization: Social Theory and Global Culture (London: SAGE Publications, 1992), p. 183. 
Regardless of the direction the globalizing world takes, the fact is that the voices of different others, which had been silenced by the dominant discourse of the life-world, are gradually resuming and echoing on a global scale. With respect to all these transformations, there is an urgent task for us to know how to cope with the new voices of change that are heard around the world. By virtue of this very urgent situation, I assume that being ignorant of the newly emerging voices of change will mean that our globalizing life-world may move further toward tragic fragmentation, while counting and nurturing the voices of difference brings more hope for a peaceful life. To celebrate the latter, we should know how the process of globalization affects the aspects of the lifeworld, and how it provides means for different peoples to flourish within a mutually enforcing dialogical framework. I shall consider the latter to be the motive behind theorizing which I refer to as the ethics of recognition in International Relations.

The basic contention in such an analysis of the globalizing world, as Ulrich Beck argues, then is that the "world of bounded and opposed societies, each in its own container, and each with its own culture, its own economy, and control over destiny of its own people", ${ }^{21}$ is becoming fundamentally contestable and consequently less reliable. More importantly, in the globalizing world, the dichotomous relationship of global and local events is becoming more and more tenuous. In these circumstances a sense of collective identity is spreading, which is intimately interrelated to the newly heard voices of change through identity and social movements. Taking these effects of globalization into account, one is provoked to re-think the definition of the territorial pattern of social

\footnotetext{
${ }^{21}$ Ulrich Beck \& Johannes Willms, Conversation with Ulrich Beck (Cambridge: Polity Press, 2000), p. 16.
} 
relations and political actions on the one hand, ${ }^{22}$ and the relationship of the local assertions of identity and culture with the challenging process of globalization on the other. ${ }^{23}$ One is also encouraged to think about an emerging world as a single place in which new identities with varying prospects of power and orientation pursue their own goals. These goals are pursued within the bewildering centerless global networks, where promises such as the strengthening of human rights and democratization come to coincide with the challenge of authenticity, the politics of being and belonging, and the threats arising from the growing unjust social-economic inequalities. ${ }^{24}$ South African controversy with American pharmaceutical product companies, Iran's pattern of dialogue for global governance at the time of the reformist president, Mohammad Khatami, and Malaysian and Singapore's claims of Asian cultural authenticity, at the roots of their remarkable postwar success, are the economic, political and cultural examples of such challenges.

Taking these affects of globalization into consideration, no longer the old world order centered on nation-state would be available; rather, attention should be paid to an emerging epoch in which cultural and ideational forces are and factors to be counted. In

\footnotetext{
22 Ulrich Beck, What is Globalization? (Cambridge: Polity Press, 2000), pp. 22-63.

${ }^{23}$ See: Ronald Robertson, "Globalization: Time-Space and Homogeneity-Heterogeneity," in Global Modernity, Mike Featherstone, Scott Lash, and Ronal Robertson ed. (London: SAGE Publications, 1995); Arjun Appadurai, Modernity at Large: Cultural Dimensions of Globalization (Minneapolis: University of Minnesota Press, 1996); Zygmunt Buman, "The Great War of Recognition," in Recognition and Difference: Politics, Identity, Multiculturalism, Scott Lash and Mike Featherstone ed. (London: SAGE Publication Ltd, 2002). ${ }^{24}$ Of the thoughtful assertions of the idea of authenticity in the globalizing world is the stress on originality of cultural life and practices versus those of the false consumerist cultural practices of the west. This stress comes from a more general argument that cultural homogeneity th reats the authentic assertions of identity. The fear is that people are possibly going to accept the western pastiche of their culture as authentic. See: Stuart Hall, "The Question of Cultural Identity," in Reading in Contemporary Political Sociology: Globalization, Politics, and Power, Kate Nash ed. (Malden: Blackwell Publishers, 2000), pp. 115-122; Arjun Appadurai, Modernity at Large: Cultural Dimensions of Globalization (Minneapolis: University of Minnesota Press, 1996); Anil Mathew Varughese, "Globalization versus Cultural Authenticity?" in Civilizing Globalization: A Survival Guide, Richard Sandbrook ed. (Albany: SUNY Press, 2003), pp. 53-58.
} 
this epoch, the world is viewed as facing a plural set of cultural and social forces challenging the taken-for-granted assumptions of the social order. ${ }^{25}$ This challenge includes, for instance, global feminist, racial, and anti-poverty movements and notably the wave of national identities confronting the patterns of exclusion. ${ }^{26}$ Accordingly, one needs to know how these transformations give rise to new forces of changes, which are taking place in almost all corners of the world. One is also encouraged to distinguish between the conventional outlooks and the new accounts stressing the historically constructed vision of the world. This latter perspective reflects the potential dynamisms for the developing and flourishing of cultural identities in global settings, either in terms of new cultural identities, or new patterns of nationalism, or even the threats of fundamentalism and terrorism. ${ }^{27}$ Understanding these transformations, therefore, urges us to investigate how the world is constantly being changed and re-ordered and how this re-ordering gives rise to a new phase in modernity which is throwing its own previous basic socio-political principles into flux. By the means of analysis of globalization and its impacts on social relations, we can argue that the project of modernity calls into question its own basic premises and articulations of social relations. ${ }^{28}$

As per life-world, it would be plausible to advance the thesis that globalization signals an end to the territorial-based assumptions in the theorizing of International Relations. That is to say, the territorial model of social relations is becoming problematic,

\footnotetext{
${ }^{25}$ Beck and Willms, Conversation with Ulrich Beck, p. 30. Also Beck, What is Globalization? pp. 23-26.

${ }^{26}$ See: Ronaldo Munck, Globalization and Social Exclusion: A Transformationalist Perspective (Bloomfield: Kumarian Press, 2005).

${ }^{27}$ For a full account of this assertion from Taylor's perspective see: Charles Taylor, "Alternative Future: Legitimacy, Identity and Alienation in Late Twentieth Century Canada," in Constitutionalism, Citizenship and Society in Canada, A. Cairns and C. Williams ed. (Toronto: Toronto University Press, 1985), pp. 183-229. ${ }^{28}$ Ulrich Beck, Wolfgang Bonss and Christopher Lau, "The Theory of Reflexive Modernization: Problematic, Hypotheses and Research Programme," Theory, Culture and Society 20, no. 2 (2003): p. 2.
} 
and can hardly fit the requirements of the globalizing life-world. The main reason for this claim is that globalization signifies a certain transformation in world order in which, due to the fluid network of exchanges, as Manuel Castells puts it, ${ }^{29}$ the socio-political notions associated with the identification of relationships among states - international relations are being challenged by new forces of change..$^{30}$ The process of globalization also gives way further to these forces, which once had been smouldering beneath the territorial model of social relations, to be re-framed in waves of struggle for recognition.

The purpose of this chapter is to analyze the impact of globalization on social relations, in general, and on dimensions of the struggle for recognition, in particular. This inquiry follows two parts. The first part reviews the three categories of interpretation of globalization and its impact on social relations and identity formation. One is Held's triadic account of globalization including hyperglobalism, skepticism and transformationalism. The other focuses on the works of Ronald Robertson and Arjun Apadurai that sees glocalization as a different transformative. And the third is the ideas of Anthony Giddens and Ulrich Beck that consider the backdrop of reflexive or high modernity. In the second part, I will explain whether globalization provides an opportunity to include the excluded different others in the life-world, in general, and within the discourse of identity, in particular. Employing Enrique Dussel's philosophy of liberation, I will argue the ethical challenge of globalization for the liberation and recognition of excluded and oppressed different others. This chapter will end with a brief

\footnotetext{
${ }^{29}$ Manuel Castells, "Grassrooting the Space of Flows," Urban Geography 24, no. 4 (1999): 294-302.

${ }^{30}$ Charles Taylor encourages us to think of the impact of globalization on transformations taking place in social relations by virtue of which peoples look for new contents of a moral life-world. See: Charles Taylor, "To Follow a Rule," in Critical Perspectives, C. Calhoun, E. Lipuma, and P. Moishe ed., Bourdieu: (London: Polity Press, 1993), pp. 35-45. It is worthy of being a bit repetitive, the forces of change are depicted by some thinkers such as Richard Falk and Fred Dallmayr as 'globalization from below'.
} 
analysis of the way through which the ethics of liberation and the ethics of recognition eventually meet.

Finally, a few words about my methodology is in order. The first point is that globalization is studied in view of the analysis of an epochal shift away from the central premise of the first phase to a second phase in modernity. While in the first modernity from the $18^{\text {th }}$ century onward - European society was transformed by various political and industrial revolutions, in the second - or reflexive - modernity the basic assumptions of modernity itself are being questioned and reflected upon. In the era of the first modernity, a process of globalization is usually considered that is mostly linear. It tends to homogenize social relations and hence, as Beck argues, challenges the we-ness of the different we. ${ }^{31}$ But, in the era of the second modernity, globalization is regarded as a reflexive process transforming social life and the conceptions of identity and community. It is in light of this transformation that I tend to understand the effects of globalization for identity formation. That is to say, in the second phase of modernity, in which the process of globalization is undermining the taken-for-granted assumptions of the first modernity, to have an accurate understanding of transformations in our life-world, we need to follow a methodology that transcends the nation-state model of social relations and instead follow a pattern which better reflects the state of flux of the second modernity. The advantage of this methodology is that it promotes an understanding of modernity as being radicalized from within, and from this standpoint, it analyzes the process of globalization.

31 Ulrich Beck, Danilo Zolo, "What is Globalization? Some Radical Questions," Journal of Philosophy of International Law and Global Politics 1, no. 1 (2005). 
The second point about my methodology is the importance of dialectic of globallocal forces in clarification of the relationship of globalization with the issue of the struggle for recognition. Noticeable in this method is a concentration on understanding globalization as glocalization, as will be explain later. This invented term is a synthesis of globalizing and localizing dynamics in a unified form. ${ }^{32}$ Central to the dialectic of globality and locality is an understanding of the emerging identities searching for the fulfillment of their own authentic modes of life in their distinct cultural settings, and acting through a mutually enforcing dialogical relationship with the different others.

\section{The Globalization Debate}

Globalization is a complex concept heavily in use - and also misused - in almost all branches of the human sciences. Although, generally speaking, globalization is referred to as the widening, deepening, and speeding of world-wide interconnectedness in all aspects of contemporary social life, beyond this it remains a contested term. It is contested by virtue of its nature, causal dynamics, and its wide-ranging implications for different aspects of human experience, especially for social and political life. In this respect, there exists perplexing disagreements on conceptualization and dimensions of globalization because each presents a specific impulse behind or holds particular dimension(s) as central in the study of globalization. For example, many might equate globalization with homogenization, westernization, and assimilation, while many others view globalization as a highly contradictory process resulting in heterogeneity and multiple consequences.

32 Ronald Robertson, Globalization: Social Theory and Global Culture (London: SAGE Publications, 1992), pp. 173-74. Beck, Conversation with Ulrich Beck, p. 232. Also see Winfried Ruigrok and Rob van Tulder, The Logic of International Restructuring (London; Routledge, 1995). 
As a result, theorists refer to globalization from different visions and for a number of diverse purposes.

There is also a sort of common agreement that globalization, by its nature, is a process that is leading to underlying social changes. But, there is a disagreement with regard to the implications of globalization for socio-political and cultural discourse. Many may see globalization as simply pulling away power or influence from locality to globality, while others view globalization not only as a pull upwards, but also as a push downwards, which creates pressure for local autonomies. ${ }^{33}$ Depending on the usage of the term in different branches of knowledge, and for a variety of purposes, globalization is defined differently: cultural globalization, technological globalization, economic globalization, ecological globalization, homogenization, westernization, internationalization, globalization of world politics, and so on. Further, being employed by different accounts in sociology, political theory, political economy, cultural and even religious studies, and assuming different impetuses behind it, globalization remains a contested term. In the field of International Relations as well, neo-liberals, neo-realists, critical theorists, and constructivists might interpret globalization differently, and as a consequence take optimistic, pessimistic, or critical positions toward the process of globalization and its impacts for social relations.

Accordingly, it is useful to adopt an account of globalization that provides the intellectual foundation for addressing the questions which animate this thesis. In this regard, I suggest David Held's and his colleagues' triadic account of globalization as hyperglobalism, secpticism, and transformationalism to be considered as an appropriate

\footnotetext{
${ }^{33}$ Giddens, Runaway World, p. 31.
} 
fit to the issue in question in this chapter. ${ }^{34}$ More particularly, his interpretation of globalization is helpful in reviewing - as I will do shortly - the perplexing literature of globalization to see which one corresponds better in elaborating the ethics of recognition. Nevertheless, there are other interpretations of globalization, omitted in Held's categorization, that would add important value to his model - especially globalization as transformation - and fertilizes it further to reveal why the struggle for recognition has become a prevailing event of our time. Among these interpretations I believe Fred Dallmayr, Enrique Dussel, and Charles Taylor deserve more attention in exploring the influence of globalization for understanding of the patterns of exclusion and oppression as well as the struggle for recognition.

\section{Transformationalist Thesis and the Issue of Recognition}

To determine the relationship of recognition and transformationalist thesis we need a brief analysis of hyperglobalist and sceptic counter arguments. The first one, hyperglobalism, sees the world as experiencing something profoundly different from what was going on before. Within this perspective, the globalizing world represents a new era; a new epoch rupturing us from the past. This is the mainstream interpretation endorsed notably by Kenichi Ohmae, Thomas Friedman, and Jagdish Bhagwati, who invest in the logic of the free market, the openness of national economies and the integration of the world economy. ${ }^{35}$ The thesis advanced by hyperglobalizers is that "globalization increasingly hollows out the state, hollows out citizenship both at the level of global

\footnotetext{
${ }^{34}$ David Held, Anthony McGrew, David Goldblatt, and Jon athan Perraton, Global Transformations: Politics, Economics and Culture (Stanford: Stanford University Press, 1999).

35 Thomas Friedman, The Lexus and the Olive Three (New York: Farrar, Straus \& Giroux, 2000). Also see: Jagdish Behagwati, In Defense of Globalization (New York: Oxford University Press, 2004); Jagdish Behagwati, Free Trade Today (Princeton; Oxford: Princeton University Press, 2002).
} 
market forces and at the level of regional blocs like the EU". ${ }^{36}$ It is argued further that the openness in markets, capital and labour enhances global competition in search of lower production costs. "This has circumscribed the range of choices of states; states become conveyer belts between citizens and global market forces". ${ }^{37}$ There is no escape from the integrating economic process of globalism. Nor is this process resistible. Globalism, hyperglobalizers argue, signals an organizationally decentralized world in which the traditional nation-state is becoming unnatural. Indeed, the whole world, according to this perspective, is gradually converging into a global market. In light of hyperglobalism, we are all seen moving, as Japanese philosopher Kenichi Ohmae puts it, toward a borderless world, where the power and legitimacy of the state is being eroded. ${ }^{38}$

In light of these observations, globalization reflects a decentralizing process in which the traditional nation-state becomes anachronistic. What is happening in this process is that national economies become the sites of transnational flows, as a result of which the ability and even legitimacy of states to control their own economies becomes questionable. Transnational corporations combined with global organizations such as the United Nations and international financial institutions such as the World Bank undertake roles which were formerly played only by the nation-states. Even decision making comes to be the task of supra-territorial players. Hyperglobalizers then rightly argue that globalization is being conceptualized beyond the earthly three-dimensional grids of longitude, latitude and altitude. This is the fact that determines the newness of

\footnotetext{
${ }^{36}$ Inescapably Side by Side: An Interview with David Held, Mikkel Thorup \& Mads P. Sørensen, Polity, (February 2004). The document is also available at: http://www.polity.co.uk/global/inescapably-side-byside.asp

${ }^{37}$ Ibid.

${ }^{38}$ Kenichi Ohmae, The Borderless World: Power and Strategy in the Interlinked Economy (New York: HarperCollins Publishers, 1999).
} 
globalization. ${ }^{39}$ In the globalizing era, as Jaon Aart Scholte puts it, concepts such as place, distance, and borders are inadequate in attempting to describe the geography of cyberspace, global warming, offshore banking, export-processing zones, human rights and so on. In other words, a further, supra-territorial aspect exists with respect to globalization, which transfers the three dimensional geography to four and consequently changes profoundly the map of social relations. ${ }^{40}$ The fourth dimension, the one that is effectively non-territorial and distance-less discredits the severity of territorialism. That is to say that although nation-states still remain key players in identifying social relations and identification of community, the sharp boundaries between national/international, internal/external, and domestic/foreign become porous. These transformations render the world into a new order by which new patterns of economic winners and losers come into existence.

In the globalizing world, hyperglobalizers argue, the old North-South division is seen as being supplanted by a global entrepreneurial order structured and governed by new global rules of the game, such as those of the World Trade Organization. ${ }^{41}$ In the new world order, the gap between the winners and losers is not as deep, since from a neoliberal perspective a relatively comparative advantage is provided in the long-term. ${ }^{42}$ Furthermore, the decline of the state - and state intervention in economic and commercial activities - is to be considered good because it is a hyper sign of liberal progression toward individual autonomy and self-determination. From the neo-liberal

\footnotetext{
${ }^{39}$ Jan Aart Scholte, Globalization: A Critical Introduction (New York: St Martin's Press, 2000), p. 47.

${ }^{40}$ Jan Aart Scholte, "Globalization: Prospects for a Paradigm Shift," in M. Shaw ed., Politics and Globalization: Knowledge, Ethics, and Agency (London: Routledge, 1999), p. 16.

${ }^{41}$ Verna V. Gehring, Ethical Dimensions of Global Development (Lanham: Rowman \& Littlefield Publishers, 2007), p. 64; also Crocker, op. cit., p. 42.

${ }^{42}$ Held, Global Transformations, p. 4.
} 
perspective, all obstacles to freedom of trade should be removed in order for people to gain true autonomy. Hence there is an inextricable relationship between the progress promised by globalization and the liberal account of freedom. And, there is no other alternative or orientation in this progression; no choice, no place to hide, as Margaret Thatcher echoed in late $1970 \mathrm{~s} .{ }^{43}$ It is no longer possible to speak of policies taking place in the confines of national territoriality. The life-world is determined by globalization, but this determination must be welcomed because it steers us toward social goods.

Hyperglobalizers certainly believe in a teleological denationalization in the nature of globalization, but they disagree about how it affects the question of identity, and by implication, the issue of recognition. Although neo-liberals, for example, look optimistically at such teleological orientation, the fact is that hyperglobalism relies on a vision of cultural and identity homogenization, and sometimes hybridisation, and weakening cultural differences and its recognition. Furthermore, globalization, as radical postmodern thinkers such as Zygmunt Bauman argue, relies on the idea of consumer society in which human will is modeled on one's choice to satisfy one's desires through the medium of the consumer market. Therefore, consumers move for their satisfaction, but the degree and nature of mobility stratifies social affairs and thus polarizes the whole globe. This amounts to a new kind of hierarchical circumstance in the world in which rich people take advantage of social life at the expense of people who are the losers. ${ }^{44}$ In this sense, globalization certainly affects everyday life, although the nature and the degree of

\footnotetext{
${ }^{43}$ See: Claire Berlinski, There Is No Alternative: Why Margaret Thatcher Matters (New York: Basic Books, 2008). To have a comprehensive analyses of this idea also see: Joseph E. Stiglitz, The Roaring Nineties: A New History of World's Most Prosperous Decade (New York: WWW Norton, 2003) and Manfred B. Steger, Globalism: Market Ideology Meets Terrorism (Lanham: Rowman \& Littlefield, 2005).

${ }^{44}$ Zygmunt Bauman, Globalization: Human Consequences, (Cambridge: Polity Press, 1998), p. 94.
} 
that effect is a crucial point of disagreement. 45 From a Gramscian perspective, we can say that globalism - to a minimal degree - results in a rift between the popular masses and the ruling class. Back to neo-liberalism, since such an effect promotes individual autonomy it is to be seen in terms of a new civilization. While drawing on an unequal social order caused by hyperglobalism, critics evaluate it as the expansion of market disciplinary neo-liberalism. ${ }^{46}$ This latter civilization tends to ignore the voices of difference and peoples, themselves, have been eclipsed.

In addition, the neo-liberal market civilization, driven by multinational corporations and multinational media across borders, set further rules of the global game, which directly affect people and their everyday life. This process has political and cultural implications since it aims at politics of supremacy in the emerging world order. Hyperglobalizers welcome this process of cultural homogeneity. In support of this perspective, they would point out that the irresistible circulation of products, fashions, and individual hedonistic culture are widely welcomed by youth everywhere. This points to a new world in which all aspects of life are affected by logic of free market. Ohmae interprets this logic in terms of a process that converges Japanese youth with Western materialism:

... for more than a decade, some of us have been talking about the progressive globalization of markets for consumer goods like Levi's jeans, Nike athletic shoes, and Hermes scarves - a process driven by global exposure to the same information, the same cultural icons, the same advertisement that I have elsewhere referred to as 'California-zation of taste'. Today, however, the process of

\footnotetext{
${ }^{45}$ See: George Soros, George Soros on Globalization (New York: Public Affairs, 2002); George Soros, The Crisis of Global Capitalism: Open Society Endangered (New York: Public Affairs, 1998); and Joseph E. Stiglitz, Globalization and its Discontents (New York: W. W. Norton \& Co., 2002).

${ }^{46}$ Stephan Gill, "Globalization, Market Civilization, and Disciplinary Neo-Liberalism," Millennium Journal of International Affairs, 24, no. 3 (1995): 399-423.
} 
convergence goes faster and deeper. It reaches well beyond taste to much more fundamental dimensions of worldview, mind-set, and even thought process. ${ }^{47}$

Within this perspective, in which globalization is interpreted in terms of homogeneity and dominance of monoculture and assimilating process, there remains no room for cultural differences and its recognition. Cultural imperialism, or homogenizing global culture, then, tends to minimize cultural resistance against the logic of the neoliberal market civilization. ${ }^{48}$ However, this kind of trend is called into question by the voices of change. Indeed, globalism - the current global market civilization - comes into conflict with peripheral cultures as a result of which a new opportunity is provided to break out of cultural homogeneity and the politics of supremacy.

Sceptics question hyperglobalist's thesis as flawed and naïve since it underestimates the power and the role of states in international economic activities. Hence, what characterizes scepticism is stress on the role of states, even in liberalization of economic activities and the promotion of individual autonomy. Sceptics are varied and cover a vast range of interpretations and criticisms of hyperglobalism. Theorists of the theory of hegemonic stability such as Robert Gilpin ${ }^{49}$ argue that economic globalism requires leadership by a dominant power, especially American. Conservative critics of hyperglobalism including Samuel Huntington ${ }^{50}$ and Kenneth Waltz ${ }^{51}$ believe that globalization is a project maintained by the dominant states. Thus, it is by no means an

\footnotetext{
${ }^{47}$ Kenichi Ohmae, The End of the Nation State: The Rise of Regional Economies (New York: Free Press, 1995), p. 30.

${ }^{48}$ To have a comprehensive analysis of this critique see for example: John Tomlinson, "Globalization and Cultural Analysis," in Globalization Theory: Approaches and Controversies, David Held and Anthony McGrew ed. (Cambridge: Polity, 2007), pp. 148-170.

${ }^{49}$ Robert Gillp in, Global Political Economy: Understanding the Intermational Economic Order (Princeton: Princeton University Press, 2001); and Robert Gilpin, The Challenge of Global Capitalism: The World Economy in the 21st Century (Princeton: Princeton University Press, 2000).

${ }^{50}$ Samuel Huntington, "The Clash of Civilizations," Foreign Affairs 72, no. 3 (1993): 22-49.

${ }^{51}$ Kenneth Waltz, Globalization and Governance (Columbia University, 1999) PS Online, (December) http://www.mtholyoke.edu/acad/intrel/globaliz.
} 
unprecedented event in the world. Social democrats, among them Paul Hirst and Graham Thompson ${ }^{52}$, criticize cultural homogeneity and its devastating effects on local traditions. In spite of all variations, however, there is a convergence of opinion among skeptical perspective challenging the assumptions of hyperglobalism, namely the belief that unfettered flow of goods, services, people and money across borders results in prosperity. For sceptics, as Held puts it, the optimist neo-liberal account of globalization is flawed since the market-based order of the world relies on marginalization and exclusion of notably Southern countries. ${ }^{53}$

Sceptics argue that most economic activities take place between the three economically-advanced regions: North America, European Union and Japan, plus a few of the emerging economies in Asia, Latin America and elsewhere. On this view, it would be naïve to speak of the neo-liberal belief in an emerging global economic integration. Rather, nationalism, protectionism, and ethnicity signal a radical process of deglobalization or disintegration of global economic integration. Furthermore, even in the case of economic regionalism, foreign investment flows remain to a great degree in the control of a few advanced economies. The multinational corporations remain tied primarily to their home states or regions, and these ties produce benefits for these affluent societies and states. ${ }^{54}$ As a result of this unequal division of economy and market, the South is becoming increasingly marginalized, underdeveloped, and dependent. In light of these observations, the sceptics tend to advance alternative approaches to hyperglobalism. For example, Herman Daly argues that national culture still continues to

\footnotetext{
52 Paul Hirst and Graham Thomson, Globalization in Question: The International Economy and the Possibilities of Governance (Cambridge: Blackwell Publishers, 1999).

${ }^{53}$ Held, Global Transformations, p. 6.

${ }^{54}$ Hirst, Globalization in Question, p. 171.
} 
exert a great amount of influence in national change resulting in the further flourished of local and national. ${ }^{55}$ Sceptics further argue that the growth of global capitalism does not mean that states are becoming irrelevant for governing the flows of economic benefits. To the sceptics, the magnitude of globalization has been exaggerated by hyperglobalizers, as David held points out:

The sceptics consider the hyperglobalist thesis as fundamentally flawed and also politically naïve since it underestimates the enduring power of national governments to regulate international economic activity. Rather than being out of control, the forces of internationalizations themselves depend on the regulatory power of national governments to ensure continuing economic liberalization. 56

Furthermore, sceptics criticise the hyperglobalist thesis that the old world political cleavages are becoming irrelevant. Quite the contrary, economic integration renders the world into a new phase of threats and fears stemming from Western global dominance. Once the world drops into an unequal hierarchical order managed by more powerful states of the North, and when our life-world falls into ethnic clashes, the illusory nature of global governance is revealed. In this respect, the sceptics are inclined to conceive of global governance and economic integration as primarily Western projects sustaining the supremacy of the West in world affairs. ${ }^{57}$ Hirst and Thompson even suggest that the world is less interconnected than it was before. Indeed, states are still the legitimate national manager of the world economy and market in spite of the explicit trend of economic internationalization. 58

The post-Marxist and poststructuralist scholarship must also be counted among the critiques of hyperglobalism. It also takes globalization as a key factor in the analysis of

\footnotetext{
${ }^{55}$ Quoted in Crocker, op. cit, p. 43.

${ }^{56}$ Held, Global Transformations, p. 5.

57 Ibid., p. 6.

${ }^{58}$ Hirst and Thompson, Globalization in Question, p. 171.
} 
global power and domination, its culture, as well as the resistance against it. ${ }^{59}$ It addresses not only the ways through which power is exercised globally, but also the process via which the collective identities are formed to resist the globalization of capitalism. Indeed, these sceptics sharply draw on the resistance of the poor against the global dominance of capitalism. From this perspective, the South has become a new site of exploitation and oppression. Hence, globalization is seen not only as the economic mode of domination, but also the cultural, social, political, and ideological dynamism of hegemony in world affairs. ${ }^{60}$

In sum, sceptics argue that hyperglobalism is a myth developed by rich countries of the North to maintain their domination over the world at the expense of the disadvantaged South. Sceptics then point out that the globalist system of capitalism operates largely based on an unfair domination of the advantaged world over the poor. What is really going on, they argue, is that global capitalism and its governing structures is a disguised version of exploitation of the South. Although not belonging to these sceptics, David Held confirms that globalist capitalism has created "systemic challenges to our humanity, to our global commons and to our rulebooks which can't be dealt with by single nation-states acting alone". ${ }^{61}$ In other words, in a globalizing world our destiny is increasingly intertwined with one another. That is why we have to move beyond an interpretation of globalism in terms of either hyperglobalist economic integration of the

\footnotetext{
${ }^{59}$ Mark Rupert, M. Scott Solomon, Globalization and International Political Economy (Lanham: Rowman \& Littlefield Publishers, 2006); Hans J. Mittleman, Globalization: The globalization Syndrome: Transformation and Resistance (Princeton: Princeton University Press, 2000); John H. Mittleman, Whither Globalization? The Vortex of Knowledge and Ideology (London; Routledge, 2004).

${ }^{60}$ David Held and Anthony McGrew, Globalization/Anti-Globalization (Malden, MA: Blackwell Publishers, 2002), p. 172.

61 Inescapably Side by Side: An Interview with David Held, Global Polity Forum, February 2004, at: http://www.globalpolicy.org/component/content/article/162/27670.html.
} 
world, or understanding the globalizing world from a sceptical perspective. The world is being transformed into a new world; the interconnected world of networks and overlapping communities.

The Transformationalist thesis looks at globalization as primarily a social phenomenon that brings about qualitative changes in all cross-border interactions. Within this perspective, globalization is conceived as an open-ended and multiple processes of change redefining, reshaping, and restructuring the life-world. The Transformationalist thesis neither refutes the existence of a kind of teleological direction in the process of globalization nor reduces it to mere economic factors. Rather, analyzes globalization beyond the dichotomous line of dispute between the hyperglobalizers and the sceptics. For the advocates of this thesis, globalization is referred to as a set of historically unprecedented processes which is turning the world more interconnected and multileveled web. At the dawn of the new millennium, globalization has become an enormous driving force behind fundamental social, political, economic and organizations changes by which the world is getting reshaped. James Rosenau, for instance, argues that the globalizing world must be analyzed in terms of a fragmegrative dialogue between continuity and change, between globalization and localization, which results in contradictions, ambiguities, and uncertainties in world affairs. As a dialectical link between the forces of globalization and localization, fragmegration reflects an epochal transformation in global life. ${ }^{62}$ Following Anthony Giddens, Scholte also argues that

62 James N. Rosenau, "Beyond Post-internationalism," in Pondering Postinternationalism: A Paradigm Shift for the Twenty-First Century, Heidi H. Hobbs ed. (Albany: State University of New York, 2000), p. 228; also Rosenau, "New Dimensions of Security: The Interaction of Globalizing and Localizing Dynamics," Security Dialogue 25 (September 1996): 255-82; and James N. Rosenau, "The Challenges and Tensions of a Globalized World," American Studies International no. 2 (2000). 
globalization has been developed not according to a predetermined historical trajectory, but through structuration processes in which actors are becoming a contextualized we. ${ }^{63}$ In a dialectical interplay with social structures, this new we highlights the importance of cultural outcomes of the process of globalization in the creation of new patterns of meaning, identity and community. From this perspective, globalization is seen to intensify intercultural relations by encouraging a number of new combinations and blurring distinctions between nations and between civilizations. ${ }^{64}$

Accordingly, from the transformationalist perspective, not only the dichotomous internal/external is discredited, but also the conceptions of national and disengaged communities are to be considered as zombie categories because of the fact that the process of globalization qualitatively transforms all of these categories. It is also simplistic to imagine the removal of states from the scene, as hyperglobalizers argue, or put all efforts in the reinforcing of statism, as sceptics hold. Rather, we must focus on an openended process of fundamental transformations via which the conceptions of identity, community are being redefined in order to contribute to the transformational world of interconnectedness and networking.

In this respect, globalization is to be conceived as a powerful transformative force which is responsible for a 'massive shake-out' of societies, economies, institutions of governance and world order. ${ }^{65}$

\footnotetext{
${ }^{63}$ To have a full account of 'structuration theory' see: Christopher G. A. Bryant and David Jary, Giddens' Theory of Structuration: A Critical Appreciation (London: Routledge, 1991).

${ }^{64}$ Also see: Jan Aart Scholte, "Beyond the Buzzword: Towards a Critical Theory of Globalization," in Globalization: Theory and Practice, Eleonore Kofman and Gillian Youngs ed., (New York: Pinter, 1996); Jan Aart Scholte, "The Geography of Collective Identities in a Global Age," Review of International Political Economy 3, no. 4 (Winter 1990): pp. 577-593; and Jan Aart Scholte, "Globalization: Prospects for a Paradigm Shift," in M. Shaw ed., Politics and Globalization: Knowledge, Ethics, and Agency (London: Rou tledge, 1999). ${ }^{65}$ Held, Global Transformations, p. 7.
} 
However, this 'shake-out' is not certain since multiple global, regional, and national forces, organizationally multilayered institutions, cultural and social movements are being engaged in its evolution. In addition, there are many overlapped and interwoven processes with many directions and channels including, but not limited to, political, social, economic, and cultural aspects proceeding on multiple, interlinked, and often, uneven tracks. Globalization is, indeed, an open-ended process moving spiral-like in multiple directions in accordance with the currents of global forces. Therefore, there is no firm evidence of deterministic-like orientation toward the erosion of national communities in favour of economic globalism and its homogenizing supportive culture. Rather, globalization is evolving in multiple directions with contradictory forces and conjectural factors. Consequently, almost all countries, and their nations are becoming functionally engaged in the complexity of process of globalization of the life-world and its effects for the social life. Within this perspective, globalization is conceived of as transformational changes undermining a uniformly integrated form of political communities with novel patterns of exclusion-inclusions, and the emergence of new winners-losers. In other words, a kind of global stratification is forming wherein, as Held argues, some states and societies are being enmeshed in a new global order to fulfil different tasks in different manners, while there are others who are marginalized or excluded. ${ }^{66}$

However, if the process of globalization is considered as multiplicity of conflictual forces following multilayered expectations in multiple directions, the world can no longer be narrated in terms of homogeneity. Nor can the world be interpreted in terms of the capitalist economic integration and its cultural justification. Rather, the multilayered

${ }^{66}$ Held, Global Transformations, p. 8 
globalization fuels heterogeneity and plurality in countless, cob-webbed channels of interactions. In this new world order, opportunities are provided for marginalized voices to come to the fore to dispute globalism and its homogenizing dynamisms and instead resonate their voice for being recognized as different. The sources of these alternative globalizations, therefore, must not be merely located in economic distributional struggles, but also, as Held rightly argues, in the struggle for recognition of difference. ${ }^{67}$ In light of this interpretation of globalization, one is convinced to argue that the transformationalist thesis is to be adopted as one of the analytical frameworks in understanding and articulating the struggle for recognition. Yet, beside this thesis there are other interpretations of globalization that further deepen our understanding of the impact of globalization on the issue of recognition.

\section{Glocalization: A Different Transformative Thesis}

Some sociologists, such as Ronald Robertson, Arjun Appadurai, and Stuart Hall come to define globalization in terms of its outcomes for the cultural arrangements of society. For them, the process of globalization results in a kind of rupture or disjuncture in coordination of the social life and the emergence of a qualitatively new form of social life. These thinkers dispute the hyperglobalist thesis and its affiliated idea that the world is becoming culturally more homogeneous. Rather, they favour a plural and even contradictory tendency in theorizing about the process of globalization and its consequences for the life-world. Robertson and Appadurai analyze globalization as a process leading to the intensification of mutual interdependence beyond national societies. This mutual interdependency is seen by Robertson as the mutual dynamism of

${ }^{67}$ Held, Globalization/Anti-Globalization, p. 172. 
globalism and localism, or universalism and particularism, which results in glocalization, a condition through which local cultures can possibly represent themselves within the global flows of ideas and information. ${ }^{68}$

Following Martin Albrow, ${ }^{69}$ who argues that globalization does not simply alter the social life, but rather signals the dawn of a new age, Robertson emphasizes the scope and depth of our consciousness of the world as a single place. The importance of the single place world lies in the possible encounter between the local and global as a wider perspective of the cultural realm beyond the economic and political aspects of globalization. As a consequence, instead of focusing on system and structure, Robertson is mostly interested in the global human condition. In light of such interest, he then argues that globalization not only involves the objectiveness of interconnectedness and networking - transformational changes in the structure - but also involves the subjectivity of cultural matters. "Globalization as a concept refers both to the compression of the world and the intensification of consciousness of the world as a whole".70 Two elements in his definition make the point of debate on the mutual dependency of global and local. One is an image of a global whole and the other human consciousness. While the first element signifies the continuation of the process of globalization in the concrete 'structuration' of the world as a whole, the latter brings about the central importance of human consciousness about a glocalizing world.

Having used as a strong counter-argument contra the idea of globalization as a process that resulting in homogeneity, glocalization refers to locality as one aspect of the

\footnotetext{
${ }^{68}$ Ronald Robertson, "Globalization: Time-Space and Homogeneity-Heterogeneity," in Global Modernity, Mike Featherstone, Scott Lash, and Ronal Robertson ed. (London: SAGE Publications, 1995), p. 30.

${ }^{69}$ Martin Albrow, The Global Age: State and Society Beyond Modernity (Cambridge: Polity Press, 1996).

${ }^{70}$ Robertson, Globalization: Social Theory and Global Culture, p. 8.
} 
global. In other words, Robertson suggests that local and global interpenetrate to the degree that local is produced by, or becomes an integral part of global. Glocalization hence means the bringing of local identities, cultures and experiences in a single place world, where our fates are undeniably bound together. That is why, as we understood from Robertson's perspective of glocalization, the current world exposes a degree of collisions between civilizational, societal, and communal narratives. ${ }^{11}$ To know the cause(s) of these collisions and fragmentation we have to look at the very interpenetration, which is taking place in the single place world and our consciousness of it. Glocalization, in this way, best addresses the contemporary life-world by which we are prompted to go beyond homogeneity or heterogeneity as the characteristics of the contemporary world. Instead, we are encouraged to acknowledge that these two seemingly contradictory characteristics are indeed complementary and interpretative..$^{72}$

The core idea in glocalization and the universal-particular interplay is better understood, when globalization is viewed in terms of not only its form but also its content. In its form globalization might be seen to result in a more homogeneous world, but in its content it reflects a heterogeneous world in which different cultural localities become authentically globalized, hence are capable of developing and flourishing. In the words of Robertson, globalization involves the simultaneity and the penetration of the two sides of the same coin that is the global and local, or the universal and the particular. ${ }^{73}$ The key analytical assumption in this thesis on globalization is that we are, witness to - and participants in - a massive, twofold process involving the

\footnotetext{
${ }^{71}$ Robertson, Globalization: Social Theory and Global Culture, p. 141.

${ }^{72}$ Ibid., p. 4.

${ }^{73}$ Ibid., p. 30.
} 
interpenetration of the universalization of particularism and particularization of universalism. Robertson is saying that the economic impulse and consequences of globalization should not blind us from seeing such an important characteristic as glocalization. Insofar as we take the economic aspect of globalization into consideration and analyze it in terms of the western development of capitalism, we might ignore the strong interpretive aspects of globalization in bringing local identities and cultures to the forefront. The empowered voices, such as Japan and the South East Asian economies, do not, in any way, reflect homogenization rather they are substantially authentic identities that developed their own cultures on a global scale. Indeed, the process of globalization is manifesting differently in the cultural capacity of distinct locals, and loses its western narration accordingly in such a way that convinces us to think of global culture combined with local identities.

Robertson offers an insightful framework for understanding globalization and the effects it has on local cultures and the emergence of local identities. His theory is constructed upon a vision of a globalizing and cultivating in itself, feeding in itself the local identities to be represented globally, and for this reason rejects any account of globalization conceiving of a world marching towards homogeneity. This vision of globalization reflects the fact that the world can no longer be seen as quite orderly and divided into fixed territorial cultures with clear-cut boundaries. The crucial point in Robertson's interpretation of globalizing world is that it draws our attention to ongoing transformations in modes of identity construction at both individual or collective levels and offers a helpful framework to understand the merger of social and identity movements. However, his theory is not immune from criticism since his theory focus on 
aspect of globalization, i.e. culture. Furthermore, he takes the global-local, also universalparticular, divisions as the presuppositions of his account of glocalization and forgets the fact that the local-global encounter is not necessarily an equal one.

The culturalist view of globalization has been inspiring for Arjun Appadurai, who observes the relationship of globalization with localization in terms of disjunctural consequences producing a variety of -scapes in almost all economic, socio-political, interpersonal, technological, environmental, and most importantly cultural dimensions. In his essay "Disjuncture and Difference in the Global Cultural Economy", Appadurai argues that -scapes are "deeply perspectival constructs, inflected by the historical, linguistic, and political situatedness of different sorts of actors: nation-states, multinationals, diasporic communities as well as sub-national and group movements" ${ }^{74}$ In this vein, the nature and orientation of the series of -scapes as the major trend in the globalizing world can hardly be grasped in individual ways. In terms of ideoscapes, for instance, we can see that key notions such as rights, freedom, and democracy are becoming master terms that are powerfully echoing from Haiti to Poland and from the former Soviet Union to Cuba, but in a distinctive pragmatic configuration. ${ }^{75}$ They have structured their political cultures around the world differently. However, Appadurai is conscious of the fact that disjunctures among the -scapes do not mean that there is no pattern or logic but only that the traditional spatial models for understanding these links will not be helpful76.

In his thought-provoking work, Modernity at Large: The Cultural Dimensions of Globalization, Appadurai follows Robertson's idea of relative autonomy of glocal cultures

\footnotetext{
${ }^{74}$ Appadurai, "Disjuncture and Difference in the Global Cultural Economy, pp. 102-103.

${ }^{75}$ Ibid., 104.

${ }^{76}$ Arjun Appadurai, Interview, interview by Anette Baldauf and Christian Hoeller at: http://www.appadurai.com/interviews.htm.
} 
by presenting his theory of imagination. The core idea about imagination is that the processes of globalization have radically altered the relations between subjectivity, location, political identification and the social imagination. Imagination in this sense comes to be the emancipatory characteristic of the process of globalization. Indeed, if the globalizing world is characterized by disjunctive flows, "one positive force that encourages an emancipatory politics of globalization is the role of the imagination in social life". This imagination allows people "to resist state violence, seek social redress, and design new forms of civic association and collaboration, often across national boundaries". ${ }^{77}$ Therefore, imagination as a social practice, provides some resources to imagine ourselves as local identities. Appadurai argues that in the era of globalization the role of imagination as a popular, social, collective fact reflects the split character of imagination as well. On the one hand, it is in and through imagination that modern citizens are disciplined and controlled, yet at the same time imagination is the faculty through which collective patterns of dissent and new designs for collective life emerge. ${ }^{78}$

This new type of imagination is considered to be a new alternative to the old and static perspective of the nation-state system of the world. Injecting the injunctions in almost all aspects of the life-world, globalization erodes the old system. Also as a definite marker, globalization creates a crisis for the sovereignty of nation-states, even if there is no consensus on the core meaning and connotation of this crisis or its generality and finality. ${ }^{79}$ In the world of flows, Appadurai argues that the "very system of nation-states is

\footnotetext{
${ }^{77}$ Arjun Appadurai, "Grassroots Globalization and the Research Imagination," Public Culture 12, no.1 (2000): 6.

${ }^{78}$ Appadurai, "Grassroots Globalization and the Research Imagination," p. 6.

79 Ibid., p. 4.
} 
in jeopardy". ${ }^{80}$ As a powerful social force, imagination serves to produce the sort of locality that escapes from globality. Contra Robertson, who views local identities becoming globalized, the current trend in the globalizing world is like something escaping from globality. It is not like de-spatialization of locality or evacuation of the special from the local; rather it is like illustrating the importance of locality. ${ }^{81}$

Empowering localities in a globalizing world is at odds with theories of globalization that are centered on homogenization and assimilation and stem from a linear project of modernity. The process of globalization rather manifests a 'condition' of disjuncture - not in terms of postmodernity, but modernity at large - as against modernity, which was a project. $^{82}$ The distinction between modernity and the contemporary reflects a rupture with the past, which is driven by a world historical shift, but in a continuous way, from a national to a postnational or transnational epoch of globalization and deterritorialization: "...the globe has begun to spin in new ways". ${ }^{83} \mathrm{By}$ drawing on a number of examples ranging from transnational philanthropy organizations to green movements and from the flow of refugees to international fashions and markets, Appadurai is certainly convinced enough to advance his thesis that globalization signals the birth of a post-national social formations; an epoch further ahead of multinational or international social formations. It is within this perspective of globalization that the relationship of the nation-state and its post-national others comes into conflict. If nation is an imagined thing, the globalizing post-national world requires us to imagine different

\footnotetext{
${ }^{80}$ Arjun Appadurai, Modernity at Large: The Cultural Dimensions of Globalization (Minneapolis: University of Minnesota Press, 1996), p. 19.

81 Arjun Appadurai, "Illusion of Permanence, Interview with Arjun Appadurai," Perspecta 34 (2002): 46.

${ }^{82}$ App adurai, "Illusion of Permanence, Interview with Arjun Appadurai," p. 46.

${ }^{83}$ App adurai, Modernity at Large: The Cultural Dimensions of Globalization, p. 58.
} 
social formations that are not confined within territoriality. This world, which reflects a kind of disjunction with past challenges to order and the orderliness of the nation-state model of social formations on the one hand, encourages the imagining of the emergence of translocalities on the other. ${ }^{84}$

This shift toward postnationalism - which is derived from the largeness of modernity - is intimately correlated to the very idea of -scape. Presumably, in the postnational era, due to the variety of -scapes and global flows, the social relations and formations can no longer be imagined confined within the boundaries of nation-states because the nation-state system is undergoing a profound and transformative crisis. Nor is the social life susceptible to simple models of push and pull, or of surpluses and deficits, or of consumers and producers. ${ }^{85}$ The post-nationalism and the derived series of '-scapes' hence must be taken as the building-blocks of a multifarious world in which globalization has forced us to live; a world which is simultaneously heterogeneous, conflicting, cooperating, and overlapping.

\section{Globalization and the Backdrop of Reflexive Modernity}

A group of sociologists among them Anthony Giddens, Scott Lash, and Ulrich Beck, discuss the implications of globalization for social formations from the perspective of reflexive or high modernity. This group distinguishes between globalism, which has grown out of the assumptions of modernity, and is espoused by neo-liberalism, and globalization, which is the outcome and at the same time the determinant of a distinct

\footnotetext{
${ }^{84}$ Arjun Appadurai, "Sovereignty without Territoriality: Notes for a Postnational Geography," in The Anthropology of Space and Place: Locating Culture, Setha M. Low, Denise Lawrence-Zúñiga ed. (Malden: Blackwell Publishers, 2003), p. 338.

${ }^{85}$ Appadurai, "Grassroots Globalization and the Research Imagination," p. 32.
} 
second phase in modernity. The core idea, which all three theorists agreed upon, is that modernity is in a stage of radicalization and self-criticism from within, and globalization must be understood in terms of the very inner radicalization of modernity and its transformation into a second phase.

The inner radicalization happens because of time-space distanciation whereby societies are stretched over shorter or longer spans of time and space. In modernity, time is separated from space due to the fact that it is separated from place/location nexus. Indeed, a new condition is created in which "place becomes increasingly phantasmagoric" i.e. locales become thoroughly penetrated by absent or quite distant social influences ${ }^{86}$ Admittedly, time-space distinction leads to the disembedding of social relations from their local context of interaction and instead allows relations that are restructured across indefinite spans of time-space. Since modernity results in the stretching of social relations across time and space, individuals are provided with tendencies to be re-embedded or 'lifted out' of the social relations from the sitatedness of specific local context of interaction with social institutions. ${ }^{87}$ This possibility of reembedding admits a dialectical relationship or a mutual radical shift from the local to the universal and vice versa.

However, modern social life and practices are intrinsically prone to selfexamination, reformulation, and alteration. This characteristic of modernity, which contrasts tradition, is called reflexivity. ${ }^{88}$ It allows modernity to examine and understand itself from within, modernize its foundations, and direct itself toward a new phase, which

\footnotetext{
${ }^{86}$ Anthony Giddens, The Consequences of Modernity (Stanford: Stanford University Press, 1990), pp. 19-21.

${ }^{87}$ Giddens, The Consequences of Modernity, p. 53.

${ }^{88}$ Beck, Giddens, and Lash, Reflexive Modernization , p. 91 . Also see: Giddens, The Consequences of Modernity, p. 36 .
} 
is the second phase modernity; the radicalized modernity. Giddens suggests that reflexivity is inherent in modernity and not something newly added to it to dissolve the foundations of modernity itself. Radicalized modernity is so unsettling that it can often lead to "the dissolution of evolutionism, the disappearance of historical teleology, the recognition of thoroughgoing, constitutive reflexivity, together with the evaporating of the privileged position of the West - move us into a new and disturbing universe of experience" (Emphasis in the original text). ${ }^{89}$ This new experience reflects the radicalization of modernity itself.

In radicalizing modernity, the national basis of social relations is being undermined and consequently different others are enabled to come together in a common social fabrication, where the assumptions of a world based on a territorial model of social relations cannot be sustained easily anymore. Indeed, radicalizing modernity reflects a globalizing the world in such a way that intimate features of personal life are interwoven with the implications of the age of flowing currents. Ulrich Beck conceives of radicalized modernity as a condition of dialogical existence - a dialogical imagination - in which the opposites of the world must be borne in our own lives as well. ${ }^{90}$ Within this perspective, globalization is conceived as the inextricable feature of our everyday life experience which is going on in here as opposed to a phenomenon 'out there'. We are part of this process from which escape is hardly possible. Indeed, the process of globalization transforms the experiential spaces of the nation-state from within (Emphasis added) often against their will and awareness, Beck argues. Therefore the 'in here' within the process

${ }^{89}$ Giddens, The Consequences of Modernity, pp. 52-53.

${ }^{90}$ Beck and Willms, Conversation with Ulrich Beck, 69. Also see: Ulrich Beck, Power in the Global Age: A New Global Political Economy, Kathleen Cross trans. (Cambridge: Polity, 2005), p. 37. 
of globalization eventually "explodes taken-for-granted understanding and institutions of national society".91 To put this differently, viewed from the perspective of radicalized modernity, globalization is a process that reorders the world's social affairs not in terms of a national model of social affairs or a world-system but rather through a process of the evacuation of a local context. That is why Beck considers globalization as a dialogical experience - a process between different others and our intimate life.

Action at a distance was always a two way process; now increasingly, however, there is no obvious direction to globalization at all, as its ramifications are more or less ever-present. The current phase of globalization should not be confused with the preceding one, whose structures it acts increasingly to subvert.92

If we are not able to understand the thrust of globalization and move with it, Beck argues, that is because of our inability to go beyond the zombie categories of the first modernity that are gradually being closed down. "Zombie categories are living dead categories, which blind the social sciences to the rapidly changing realities inside the nation-state containers and outside as well".93 To put this a bit differently, these are concepts associated with the first phase modernity that we still use in our research, while they are no longer applicable in a globalizing world. By this contention, Beck opens up a new perspective in understanding the reflexive modernity as the backdrop of globalization. Zombie categories make us blind to observing the process of transformation to radicalized modernity, a second phase in modernity in which the national model of social relations disappears. This inability hinders us to properly analyze

\footnotetext{
91 Ulrich Beck, The Cosmopolitan Vision (Cambridge: Polity, 2006), p. 101. Also see: Giddens, "Living in a Post-traditional Society," in Reflexive Modernization, p. 95 and Ulrich Beck, What is Globalization (Cambridge: Blackwell, 2000), p. 73.

${ }^{22}$ Giddens, "Living in a Post-traditional Society," in Reflexive Modernization, p. 96.

${ }^{3}$ Ulrich Beck, "Cosmopolitan Society and its Enemies" Theory, Culture \& Society 19, no. 1 (2002): 23. Also see: Mitchell Dean, Governing Societies: Political Perspectives on Domestic and International Rule (Maidenhead: Open University Press, 2007), pp. 23-43.
} 
the process of globalization in our everyday life experiences. To put it differently, the problem with a lack of appropriate vision to globalization is that we continue to analyze globalization according to the horizons of the first phase of modernity, and these inappropriate horizons "distilled into a priori and analytic categories, still mould our perceptions, they are blinding us to the real experiences and the ambiguities of the second modernity". ${ }^{94}$

To have an appropriate way to deal with globalization as a process 'in here' we need to transfer our thinking away from the taken-for-granted premises of the first phase of modernity. We also need to cope with theoretical challenges that result from the process of transferring to a different phase in the analysis of social relations. This new phase is where the linear orientation of modernity ceases and a system develops which is constructed of multiple orders in light of several simultaneously existing perspectives. The linear theories of modernity pose themselves as absolutes and "refuse to apply or relativize themselves to themselves" and advance the thesis that "modernity keeps in store for everything it encounters" ${ }^{95}$ This approach to modernity is being ceased and transferred to a radical state. Hence, we need to distinguish systematically between the two phases of modernity and keep all changes in thinking. The challenge with this transformational thinking stems from a transition from modernity towards a system of polarized modernity/ies. To understand such a radical transformation, a fair starting point is discernable between the nation-state model of social relations and a non-nationstate model. We also need to think about the fundamental difference between structure as

\footnotetext{
${ }_{94}$ Beck, Conversation with Ulrich Beck, p. 19.

${ }_{95}$ Ulrich Beck, The Reinvention of Politics: Re-Thinking Modernity in the Age of Social Order (Cambridge: Polity Press, 1997), p. 13.
} 
the logic of the first phase modernity, and flow as the logic of reflexive modernity. Since we are living in a state of flows, our old understanding of social relations is to become obsolete.

Discerning between the two phases of modernity, accounts for two different visions of globalization. Understanding globalization in accordance with the territorial model is an additive approach to the issue in question. Through this lens globalization is understood as something external which is added to a pre-existing system. The idea of globalization as interconnectedness of the world springs from this vision of modernity. The other understanding is a substantive way of conceiving of globalization as an internal feature to the territorial model. This vision of globalization, which is developed in accordance with the logic of reflexive modernity, does not consider social relations like something added to a national container; rather globalization is seen as something from within; something in here, as already explained. ${ }^{96}$ This vision conceives of globalization as global orders engaging dialogically in our everyday life experiences. That is to say, the latter vision of globalization affects locals substantially, because the local and the global come into an inescapable dialogical relationship, where "both are developing in something new, into a global sense of place".97 We need then to grasp globalization in its substantive sense at the moment that modernity is being radicalized from within. Globalization in this sense must be understood as a process in which events at one pole of distanciated relations often produce divergent or even contrary occurrences at another. ${ }^{98}$

\footnotetext{
${ }^{96}$ Beck, Conversation with Ulrich Beck, p. 39.

${ }_{97}$ Ibid., p. 43.

${ }^{98}$ Giddens, Modemity and Self-Reflexivity, p. 22.
} 


\section{Globalization: Exclusion or Inclusion?}

The transitional period to the radicalizing phase of modernity, when the national model of social relations begins to weaken, necessarily impacts the construction of identity and its representation. At the moment when the dynamism of modernity begins to transfer from its taken-for-granted premises to the radicalizing state, the discourse of identity is also transferred to a new mode of identity formation and representation. Indeed, in the radical phase a certain kind of 'meta-change' takes place in the coordinates of the social relations that directly affects the discourse of identity. Therefore, we are forced to think of identity in a qualitatively new way than older, typical national model. ${ }^{99}$ In the simple period of modernity, people outside of North Atlantic democracies were, to different degrees, excluded from the modern narration of identity. ${ }^{100}$ But, in the globalizing world a new consciousness is emerging among the peoples to present themselves in global settings. In this sense, globalization creates the possibilities for an end to exclusion. That is to say, that globalization as dynamism of exclusion has the potential to be regarded as a manner of inclusion. Drawing on Enrique Dussel's philosophy of liberation, I argue that globalization - once seen in the light of modernity signals a historical rupture with the past epoch wherein different others were excluded. Dussel sees the excluded people as victims of the first phase of modernity during which the Eurocentric world system was constructed. Globalization, then, in the sense that it is referred to here, urges an ethics of liberation of the victims. ${ }^{101}$

\footnotetext{
${ }^{99}$ Beck, Conversation with Ulrich Beck, p. 18.

100 Thomas Bridges, The Culture of Citizenship: Inventing Post-Modern Civic Culture (New York: State University of New York Press, 1994), p. 2.

${ }^{101}$ Enrique Dussel, "Globalization and the Victims of Exclusion: From A Liberation Ethics Perspective," The

Modern Schoolman: Quarterly Journal of Philosophy LXXV (1998): 119-155.
} 
In view of this perspective, I argue that globalization, as it was defined in terms of reflexive modernity, brings about fundamental changes in our mode of thinking in regards to human beings, our definition of identity, the patterns of meanings, and the relationship between the individual and society as a whole. By the first phase modernity, globalization as an emerging vision of humanity enhanced by new technological knowledge resulted in economic expansion and domination, as well as Western cultural homogeneity. But, in terms of reflexive modernity, globalization can be a means of promotion of ethnic diversity, multiculturalism, and as a whole, inclusion through intercultural dialogue and recognition. According to Dussel, this perspective of globalization "must look, as a matter of urgency, at the liberation of the victims whose lives have been plundered and limited" (Emphasis in the original text). ${ }^{102}$ In light of such transformational changes to radicalizing modernity one is urged to think of transforming ways through which the excluded people - the victims of the south- think of themselves, grasp their identity, and sort out their political affiliations and loyalties.

When a victim discovers his or her situation, that is, when one recognizes oneself as a victim because of material oppression or formal exclusion, then a critical attitude may emerge. This allows the victims to better know their condition through development and participation. The existence of victims makes the need to transform society, its institutions and forms of organization, an ethical obligation ${ }^{103}$.

If globalization is to be understood in terms of such transformations at the coordinates of social relations, institutions, discourse and practices, the discourse of identity should also be understood differently. That is to say, the discourse of identity must also be transformed in light of the ethics of liberation as well as inclusion. From this

\footnotetext{
${ }^{102}$ Enrique Dussel, "Globalization, Organization, and the Ethics of Liberation," Philosophy and Social Criticism 14, no. 3 (2006): 504.

${ }^{103}$ Dussel, "Globalization, Organization, and the Ethics of Liberation," p. 503.
} 
point, the struggle of others for recognition of their differences enters into a new phase, when the negation of liberation is resisted. In the language of Dussel, it is a new epoch by which "the negation of the negation of liberation begins". 104

In light of these observations, I contend that the discourse of identity must no longer be thought of in terms of our old conceptualization of the world because the world can no longer be conceived of in the previous ways. ${ }^{105}$ Nor can the excluded others - the victims - take part in the social formations and relations of the life-world unless they are conscious of their excluded condition. ${ }^{106}$ Rather, in a globalizing world, which is constructed of interlaced social events and relations that at a distance are tied together with local contextualities, we are urged to acknowledge the inclusion of excluded voices. Indeed, "we must begin with the realization that globalization commands that we visualize new categories of ethical analysis" instead of the zombie categories of the first modernity. ${ }^{107}$ In the globalizing world, identities narrated under the rubric of a national model of social relations and its derivative global-local, universal-particular and us-them nexus, have almost become obsolete. This assertion means that globalization, in its substantive sense and beyond its procedural globalism, facilitates and enables global and local attitudes to come together to define a global culture that represents inseparably intertwined identities. Indeed, part of globalization has become itself localized, while locals have partly become globalized; an idea that is very similar to Roberston's account

\footnotetext{
${ }^{104}$ Enrique Dussel, "Beyond Eurocentrism: The World System and the Limits of Modernity," in The Cultures of Globalization, Fredric Jameson and Masao Miyoshi ed. (Durham: Duke University Press, 1998), p. 20. ${ }^{105}$ Stuart Hall, "Old and New Identities, Old and New Ethnicities," in Culture, Globalization and the WorldSystem Anthony D. King ed. (Minneapolis: University of Minnesota Press, 1997), p. 45.

${ }^{106}$ Dussel, "Globalization, Organization, and the Ethics of Liberation," p. 503. Dussel, "Globalization, Organization, and the Ethics of Liberation," p. 503.

107 Eduardo Mendieta, "Beyond Universal History: Dussel's Critique of Globalization," in Thinking from the Underside of History: Enrique Dussel's Philosophy of Liberation, Linda Martin Alcoff and Eduardo Menieta ed. (Lanham: Rowman \& Littlefield Publishers, Inc., 2000), p. 124.
} 
of glocalization. This approach to identity signals the emergence of a rooted cosmopolitan sense of a we, which is no longer set against the different other.

Accordingly, in a globalizing world and in a time in which the process of liberation and individualization is becoming stronger than ever, the individual narration of the self comes to be interwoven with the narration of the excluded other or the victim. To clarify this assertion further, it is to be argued that in the globalizing world it is not easily possible to monopolize the world-system from top and ignore the different others; the victims, who suffer from poverty, domination, and exclusion. Instead, due to rising levels of consciousness the world must negate the exclusivist manners and proceed toward an inclusionary manner and favour "the liberation of the victims whose lives have been plundered and limited". 108

Under such conditions of glocality, even the national can hardly be conceived as national but rather "[t]he national has to be rediscovered as the internalized global". 109 From the positivity of interpreting globalizing as a radicalizing process from within (Emphasis added) it is not easy to conceive of identity in terms of an unencumbered being who has been abstracted from the requirements of real life in a globalizing world. It is also not plausible to ignore the current context of the life-world within which our fate is shared with the other - the strangers - fellow humans. Instead, by passing from the old narration of the self - the passage of liberation - a cosmopolitan sense of we is formed that requires to negate the negation of different others. ${ }^{110}$ The individual human beings might therefore be conceived as unencumbered, but at the same time, they are situated by

\footnotetext{
${ }^{108}$ Dussel, "Globalization, Organization, and the Ethics of Liberation," p. 504.

109 Ulrich Beck, "Cosmopolitan Society and its Enemies," p. 23.

${ }^{110}$ En rique Dussel, The Underside of Modernity: Apel, Ricoeur, Rorty, Taylor, and the Philosophy of Liberation, Eduardo Mendieta trans. (Atlantic Highlands: Humanities Press, 1996), p. 6.
} 
a double sense of belonging to the background that constitutes their identity and their ties with the different others. In this sense, the conception of identity extends beyond its inwardly derived narration and instead enters into a socially derived and dialogically inspired construction, that is, in relation to the others. This is at this moment that, to a great extent, negation of exclusion and domination becomes the central ethical question of reflexive modernity. ${ }^{111}$ This approach, in articulation of the self, is becoming the paradigm of identity politics in a globalizing world.

In this transformation to the radicalized or reflexive modernity, the selfhood of either us or them - the others - is re-embedded in a new form with global ties. That is to say that globalization facilitates and accelerates the emergence of new social and political regroupings calling the categories of first phase modernity into question. Examples of these new types of identities are the global-wide network of non-governmental organizations and transnational social movements that are seeking to rally constituencies for globe-spanning issues that are related to the environment, gender, human rights, democratization and labour, as well as many other types of policies. Furthermore, globalization facilitates resistance of other cultures vis-à-vis the West's hegemonic position in the world. Dussel eloquently further highlights this resistance arguing that the gravity of resistance of the rest against the West lies in a challenge to a Eurocentric philosophy of modernity that provided the West with a differentiated advantage over the world. He then looks at the underside of modernity to explain how Western civilization has culminated to its zenith at the expense and exclusion of different others. That is why he - in almost all of his works - argues that modernity cannot be understood

\footnotetext{
${ }^{111}$ Dussel, The Underside of Modernity, p. 9.
} 
comprehensively unless we give voice to the victims of this project. And, it is at this point that Dussel comes into a dialogue with Taylor's interpretation of modernity, which includes admiration, respect and recognition of other cultures and concludes that "respect and recognition of the Other, ideally or factically, is the ethical moment (and as such ethical and rational) par excellence" (Emphasis in the original text).112

It follows that resistance against the West along with newly emerging global identities, signal a potential paradigmatic shift in construction and representation of our life-world in which identity, nationhood, fate, pleasure etc., can no longer be located nationally or locally, but rather globally or glocally, whether in the shape of globally shared collective futures, capital flows, impending ecological or economic catastrophes, global foodstuff chains or the international 'Esperanto' of pop music. ${ }^{113}$ Also, the current life-world, a world of high modernity, exhibits new ways of human sociability and new types of politics which are qualitatively different from the premises of the first phase of modernity. The construction of alternative projects of modernity - based on the glocalized cultural identities in an era of high modernity - is a possible, yet "a responsible 'dis-covering' as an answer to the interpretation of the Other," through a real dialogical manner. ${ }^{114}$ This manner rationally and procedurally prompts us toward overlapping consensus with others, and as a consequence helps us understand and make an attempt for an ethics of liberation - according to Dussel - or an ethics of recognition - in accordance with Taylor - of the oppressed and excluded different others.

\footnotetext{
112 Enrique Dussel, "Modernity, Eurocentrism, and Trans-Modernity: In Dialogue with Charles Taylor," in The Underside of Modernity, p. 146.

113 Beck, "Cosmopolitan Society and its Enemies," p. 30.

114 Dussel, "Modernity, Eurocentrism, and Trans-Modernity: In Dialogue with Charles Taylor," in The

Underside of Modernity, p. 148.
} 
In conclusion, once seen in the light of the radicalized reflexive modernity, encounters all aspects of the life-world affecting social formation and relations as well as narration of identity. Within this analysis of globalization, territorial conceptions and methodologies become, to a great extent, obsolete. Indeed, from the perspective of reflexive second modernity/ies ethical challenges are set against the homogenizing logic of globalization as a result of which new forces of change come to the fore. Spanning from the challenge of the South to global non-state actors, these forces are engaged in everyday life; the life experienced dialogically. In light of these observations, cultural identities can demonstrate and act in global settings, where we experience a certain sense of common fate and cosmopolitan responsibility. To analyze all these transformations, which are taking place at the core sphere of social formation and relations, we must transcend the linear logic of first phase of modernity, and hence extend beyond territorial assumptions of the life-world and the meanings that are extracted from it. In other words, we need to be conscious of the fact that we are living in a world of flows in which a countless number of opportunities are provided through which the battle-like competition between the forces of globalism and localism is sublimated and lifted-up. That is to argue that we are entering into a glocalizing world in which a cosmopolitan sense of a we is being formed.

In the glocalizing world, globalization is seen not merely from the perspective of homogenization, exclusion, and or oppression of different others. Rather, it might be seen with potentials to liberate and include the excluded - victims - others either individually or in a group. In other words, globalization, being framed within reflexive modernity, is an opportunity through which the oppressed others can resist the dynamism of exclusion and oppression. Here, the liberation of the victims comes to be the zeitgeist - the spirit or 
temper - of our time. But, liberation is more than populist plans or radical movements. It is rather a philosophy; a philosophy of liberation. It is a philosophy that negates the negation of different others and instead recognizes their equal value. That is why I contend that exploring the positive potential of globalization for the inclusion of different others is to be itself a beginning to reflect on the philosophy of liberation. This reflection, I argue, is to be the true spirit of our time; a time fundamentally different from the first modernity. In the following chapter, I will analyze how liberation through recognition of difference is contemplated and philosophized, and how this contemplation is manifested in different accounts of liberation. 


\section{Chapter 2}

\section{Difference and Recognition in International Political Theory}

... the great evils of human history-unjust war and oppression, religious persecution and the denial of liberty of conscience, starvation and poverty, not to mention genocide and mass murder- follow from political injustice, with its own cruelties and callousness... Once the gravest forms of political injustice are eliminated ... these great evils will eventually disappear.

John Rawls, The Law of Peoples, pp. 6-7.

The process of globalization affects the emergence of new identity consciousness and the struggle for recognition and liberation. This chapter analyzes how struggle for recognition has been addressed by a variety of theories. This analysis mainly covers the liberal-cosmopolitan tradition and its critics. The employment of the term liberalism in this analysis does not mean liberalism as an ideology or liberal approaches to study of international relations. Rather, the liberal tradition is analyzed as a philosophical account based on liberal virtues such as individual freedom, equality and justice in such a way that addresses the issue of recognition. And, by its critics I mean communitarianism and those approaches charging liberal normative theory far ignoring cultural and identity differences. My purpose in this analysis is to show how both liberal normative theory and its critics, more or less, appreciate the issue of difference but not necessarily the recognition of difference. In other words, they tolerate the existence of difference instead of recognizing it (Emphasis added). The latter focuses on the "potential for forming and defining one's identity", and by implication, recognition of equality of difference.115 The

\footnotetext{
115 Taylor, "The Politics of Recognition," p. 236.
} 
former, especially the liberal theory, ignores recognition of as the foundation of identity and merely looks for equality among different identities.

The chapter is divided into two parts. The first part is dedicated to the analysis of liberal normative theory as related to the issue of difference. In this part the ideas of John Rawls will be examined. There are two reasons for choosing this thinker. One is fame as a liberal thinker with recurrent interests in moral issues pertaining to International Relations. The other is that he has developed his account in accordance with a theoretical linkage between political theory, ethics, and International Relations Theory. This linkage deals with a range of moral issues such as justice, global equality, human rights, the question of poverty and many emerging issues that can be added to the list ${ }^{116}$. Therefore, we need to grasp the core insight of liberalism, lay it bare in a clear manner, and then expose its strengths and weaknesses. If this job is accomplished successfully, it will then be possible to concentrate on analysis of the discontents of liberalism.

The second part is dedicated to an analysis of the concerns of critics of liberal normative theory about the question of identity and cultural difference. In this regard, I will examine the cosmopolitan-communitarian debate, post-foundationalism accounts, and Critical Theory. The relevance of the issue of difference and its recognition is the focus of my investigation. As it will be explained shortly, by and large the abovementioned normative theories, appreciate and acknowledge the existence of difference, but not recognition of difference as a vital need in the life-world.

\section{Part One: The Question of Difference in Liberal Normative Tradition}

\footnotetext{
116 Nicholas Rengger, "Political Theory and International Relations: Promised Land or Exit from Eden," International Affair 76, no. 4 (2000): 758-760.
} 
In it various guises, the liberal normative tradition attempts to protect basic liberties and individual rights from the "oppressive use of government's monopoly of legal force". ${ }^{117}$ In other words, liberalism tends to see the state as an apparatus of public administration serving civil society conceived, as a system of market-structured interactions of private persons and their interests. ${ }^{118}$ In late twentieth century, and coinciding with the diffusing democratic values with spreading process of globalization, normative liberal theory turned into a new phase cutting across the boundary of political theory and International Relations Theory. This retrieval was aimed at addressing the questions of what a democratically good community might be, how democratic values can be transplanted to international domain, and how the process of globalization can possibly mediate between good democracies and a democratic world order. ${ }^{119}$

Aiming at addressing the above questions, contemporary liberals, notably those within the context of analytical philosophy, such as John Rawls, draw on the principle of autonomy and the acknowledgment of fundamental rights and freedom excluding any substantive conception of the good life. This approach which is known as procedural liberalism primarily appreciates the meta-political level of due process over any substantive view about the ends of life. ${ }^{120}$ The major point in perspective is to respect

\footnotetext{
117 John Rawls, Political Liberalism (New York: Columbia University Press, 1996), p. 146, note, 13.

118 Jürgen Habermas, "Three Normative Models of Democracy," in The Political, David Ingram ed. (Malden:

Blackwell Publishers, 2002), p. 151.

${ }^{119}$ An th ony G. McGrew, The Transformation of Democracy: Globalization and Territorial Democracy (Cambridge: Polity Press, 1997), p. 232.

${ }^{120}$ Procedural liberalism has become known by Michael Sandel and Charles Taylor, both of whom believe that this model of liberalism undermines republican virtues, hence fails to deal satisfactory with issues of virtues and identities. See: Michael Sandel, Democracy's Discontent: America in Search of a Public Philosophy (Cambridge: Belknap Press of Harvard University Press, 1996), p. 70. Charles Taylor also criticizes difference-blind and atomistic procedural liberalism in his writings. See for example: Taylor, "The Politics of Recognition," pp. 245-249.
} 
individual preferences and values pursued in light of the 'formula of humanity'121. However, Charles Taylor and like-minded thinkers, such as Michael Sandel, believe that procedural liberalism results in social fragmentation since it disregards people's distinct vision of substantive ends. ${ }^{122}$ Procedural liberalism fails to provide general conditions for a strong democratic politics or 'republican' self-rule. ${ }^{123}$ Taylor is clear that this model is difference-blind liberalism developed on grounds of neutrality; hence it is impractical in a world of diversity, plurality, and contentious difference. By contrast, he promotes the thesis that autonomy requires cultural support, and all cultures deserve respect and equal rights. In this second model of liberalism, the substantive liberalism, we not only let different others survive, but their worth is acknowledged. ${ }^{124}$

These two models of liberalism i.e. procedural and substantive are of the most challenging debates in the globalizing era. However, in a globalizing world and amidst an uprising of identity consciousness, the adherents of liberal normative theory are faced with a fundamental and pressing question: How to define and recognize the right of distinctive identities struggling for recognition? John Rawls's principle of international justice ${ }^{125}$ and Charles Beitz's moral cosmopolitanism, ${ }^{126}$ present the two most prominent liberal responses to the aforementioned question. For both of them any quest for

\footnotetext{
${ }^{121}$ The 'formula of humanity', along with the 'universal law' and the 'kingdom of ends' are the three formula of 'categorical imperative, developed by Kant as the highest values in morality. In order to read the detail of this account see Immanuel Kant, Groundwork of the Metaphysics of Morals, Mary Gregor ed., (Cambridge: Cambridge University Press, 1997), par. 428-430.

${ }^{122}$ Michael Sandel, Liberalism and Limits of Justice (Cambridge: Cambridge University Press, 1982). Also, Michael Sandel, Liberalism and its Critics (New York: New York University Press, 1984).

${ }^{123}$ Charles Taylor, "Living with Difference," in Debating Democracy's Discontent: Essays on American Politics, Law, and Public Philosophy, Anita L. Allen and Milton C. Regan ed. (Oxford: Oxford University Press, 1998), pp. 212-26; and Charles Taylor, "Cross-Purpose: The Liberal Communitarian Debate", in Charles Taylor, Philosophical Arguments (Cambridge: Harvard University Press, 1995), pp. 181-203.

${ }^{124}$ Taylor, "The Politics of Recognition," p. 250.

${ }^{125}$ John Rawls, The Law of Peoples (Cambridge: Harvard University Press, 1999).

${ }^{126}$ Charles Beitz, Political Theory and International Relations (Princeton: Princeton University Press, 1999).
} 
recognition should be searched for in liberal universal moral law, no exception is permitted: "No one has the right to self-determination or a right to secession, at the expense of subjugating another person". 127

In spite of the critics advanced by alternative approaches against liberal normative theory, this tradition is still philosophically rich and powerful, and has attracted attention in normative theorizing, both in the political sphere of domestic affairs and International Relations. The richness and advantages of liberalism are traceable to the great importance accorded to individual values, on the one hand, and the victory of liberalism over Fascism and communism in the recent past and resulting in the Universal Declaration of Human Rights, on the other. However, due to its proceduralist logic and its resulting differenceblind eyes, victorious normative liberal theory has recently confronted new challenges launched by critics. The new challengers that are rapidly growing up, have interrogated liberal assumptions on identity of moral agency, especially procedural solutions offered by liberal-cosmopolitans for raising identity consciousness in globalizing world.

\section{John Rawls's Pluralist Approach}

John Rawls became most famous because of $A$ Theory of Justice, which is perhaps one of the most read texts in the contemporary liberal tradition. The book originates from two articles "Justice as Fairness"128 and "Distributive Justice",129 published respectively in 1958 and 1967. Rawls aimed to develop a moral theory grounded upon an account of rational agency as the constituent of social contract theory. In other words, while the focus of traditional social contract theory is on agreement between people in a state of

\footnotetext{
127 Rawls, The Law of Peoples, p. 38.

${ }^{128}$ John Rawls, "Justice as Fairness," The Philosophical Review 67, no. 2 (April 1958): 164-94.

129 John Rawls, “Distributive Justice," in Philosophy, Politics, and Society, Peter Laslett ed. (Oxford, Blackwell, 1962).
} 
nature to enter into a society to which they are obedient, for Rawls social contract is based on moral principles. In fact, his theory does not originate primarily from a political obligation; but rather from a conception of autonomy expressed politically. This model of theorizing was very much under the influence of Rousseau's moral idea of transforming from a "private will" into a "general will" of individuals when a social compact is constituted. ${ }^{130}$ This model should provide the moral justification for a rational social theory created by the 'general will' of self-interested individuals.

This theory takes its plausibility from a kind of rational choice conviction according to which individuals get into a bargaining game based on the equality of their rights and moral personality. ${ }^{131}$ The bargaining game aims to provide a rational criterion to illustrate the virtue of social institutions and practices within which individuals interact. The participants in social practice or those who are affected by it, are subjected to two principles of justice: Firstly, they have their own equal right to the most extensive liberty, and secondly, social and economic inequalities are to be arranged so that they are both reasonably expected to serve everyone's advantage. These principles contribute to the common good and express justice as fairness. ${ }^{132}$ Justice as fairness in social practice reflects the commitment to moral principles even by those who might be disadvantaged.

Justice as fairness is the yardstick to measure whether a social practice is just or not. The justness of practice is weighed against the "original position" upon which free social contractors have agreed. This position is a hypothetical state of affairs, which

\footnotetext{
${ }^{130}$ To explore the influence of Rousseau on Rawls see: Patrick Neal, "In the Shadow of the General Will: Rawls, Kant and Rousseau on the Problem of Political Right," The Review of Politics 49, no. 3 (Summer, 1987): 389-409; David Boucher, "Uniting What Right Permits with What Interest Prescribes; Rawls' Law of Peoples in Context," in Rawls' Law of Peoples: A Realistic Utopia, Rex Martin and David A. Reidy ed. (Malden: Blackwell Pub., 2006), pp. 29-32.

${ }^{131}$ John Rawls, A Theory of Justice (Cambridge: Harvard University Press, 1971), p. 17.

${ }^{132}$ Rawls, "Justice as Fairness," pp. 165-66.
} 
insures that the fundamental agreements reached in it are fair. This fact yields the name 'justice as fairness'. ${ }^{133}$ However, the parties in the "original position" lack any particular advantage at the expense of others. They make their decisions under the "veil of ignorance" disregarding of any kind of particularity such as historical context of the contractor's society: "No one knows his situation in society nor his natural assets, and therefore no one is in a position to tailor principles to his advantage". ${ }^{134}$ Since individuals in the original position move from their own individual will toward a general will, the veil of ignorance removes the entire knowledge of particularity in the conclusion of the impartial agreement. Correspondingly, the agreement concluded in the original position belongs to all generations, in all times, in all liberal societies in the realistic world.

The point of $A$ Theory of Justice can be put somewhat differently to serve the purpose of this work in international thought. This theory has basically had a metaphysical foundation which facilitated the universalization of the particular account of liberalism to domestic affairs of all liberal societies. Its influential achievement was an account of human rights standing at the heart of a liberal theory of justice. Rawls, in a later work, "Justice as Fairness: Political not Metaphysical", tried to further clarify his moral account arguing that his idea of justice as a practical conception is applicable beyond any controversial accounts about the status of political and moral values. Indeed, Rawls holds that legitimated stability for liberal societies depends on detachment of liberalism itself from any contentious comprehensive moral and metaphysical doctrine. This move from liberalism as a way to liberalism as a philosophy to govern only political life is the project of political liberalism. What, in fact, he was trying to do was an

\footnotetext{
${ }^{133}$ Rawls, A Theory of Justice, p. 17.

134 Rawls, Political Liberalism, p. 139.
} 
encompassing plan bringing all opposing religious and philosophical doctrines together under the title of "overlapping consensus" which pertains to constitutional liberal democracies. The "overlapping consensus" is, indeed, a kind of interactive reasonable consensus among comprehensive views, which generate the culture of liberal tolerance in the public sphere. Since in liberal societies reasonable views are respected, pluralism is strengthened and cooperation among different people holding different comprehensive views is promoted.

Rawls completed the shift from metaphysical doctrine toward a more deliberately political account of liberalism in his work Political Liberalism. This shift removed any doubt about how his theory is extended beyond domestic affairs; because, from a liberal perspective, there remains no legitimate ground to question the other comprehensive doctrines as long as they are reasonable. It is within the perspective of this work that a new conceptual framework is provided to develop the necessity of cooperation with nonliberal societies. This cooperation is justified by referring to the moral duty of liberal people. Liberal people must assist the non-liberal people to enter into the society of people and they must acknowledge the plurality of reasonable comprehensive doctrines in the society of peoples. Apparently, this account of pluralism was a response to changeable social conditions.

Rawls goes into the international implication of this shift in his work The Law of Peoples. He acknowledges that his intention is to elaborate the relationship of liberal with non-liberal societies based on the very idea of reasonableness. Such a relationship is desirable because it promotes pluralism as a result of which a more peaceful world order will become possible. His justification is that human rights and justice, as the core 
assumptions of liberalism, can potentially prevent oppression and all forms of political injustice. In accordance with this argument, just as a citizen in a liberal society must respect other people's comprehensive doctrines, so liberal societies "must respect other societies organized by comprehensive doctrines provided their political and social institutions meet certain conditions that lead the society to adhere to a reasonable law of peoples". ${ }^{135}$ In this perspective, many problems of the contemporary society of peoples, such as unjust wars, will be left aside altogether. ${ }^{136}$

This account of acknowledgment of non-liberal people reflects the fact that difference in culture and political institutions of peoples does not necessarily come into collision with one another provided that their comprehensive ideals are pursued in specification of a reasonable and just society of peoples. ${ }^{137}$ To be sure, some outlaw states - such as the People's Republic of China, North Korea, and the Islamic Republic of Iran do not constitutionally respect the principles of the basic rights, freedom, and justice, and are, therefore, unwilling to cooperate fairly with other peoples. Worse is that those states pursuing their unreasonable comprehensive ideal, often fall into a war-like position with other people. In this case, liberal peoples should encourage those states, at least, to a peaceful co-existence, and in some cases to sanction and even forcefully respond; Rawls hopes the outlaw states come into cooperation with liberal states.

In spite of its promising inclusive orientation toward the appreciation of different others, Rawls' theory of international relations has its shorcomings. If there is cooperation among societies, for example, it results from the fact that they are necessarily

\footnotetext{
${ }^{135}$ Rawls, The Law of Peoples, p. 43.

136 lbid., pp. 6-8.

137 Ibid., p. 18.
} 
enmeshed in a network of glocality. Then, isn't the idea of international justice empirically flawed? Rawls answers this question in the negative; he claims that criticism derives from a misunderstanding of his account of international justice. Rawls does not consider peoples as they are under existing conditions; but rather views them from a moral point of view, i.e. the view in which liberal peoples collaborate with one another fairly and with non-liberal peoples based on mutual recognition of independence and equality.

He conditions the recognition of non-liberal peoples with decency, even though they may be hierarchical. ${ }^{138}$ The idea of decent hierarchical people is a theoretical construct, however, that has been developed to determine the threshold of toleration in those societies. Decent societies respect certain rights and obligations such as political rights and the rule of law, minimum requirement of civility. Considering these two specifications, it is the duty of liberal well-ordered peoples to cooperate with non-liberal decent societies as bona fide members of the "society of peoples". However, liberal peoples must criticize decent people with the hope that one day they become liberal. Evidently, this criticism should not result in a hostile position and coercive intervention to change their way, but rather they are morally committed to respect the integrity, political independence and autonomy of decent peoples. ${ }^{139}$ This moral commitment to recognize decent peoples comes to be the cornerstone of the peaceful "confederation of peoples".

An interesting example given by Rawls to justify his theory is "Kazanistan" - a hypothetical decent people with hierarchy. In Kazanistan, Islamic law is favored and the principle of secularism is not tolerated, but plurality of religions is respected and the other believers are free in their worship and can even flourish. In addition, Kazanistan is

\footnotetext{
${ }^{138}$ Rawls, The Law of Peoples, p. 61.

${ }^{139}$ Ibid., p. 63
} 
not aggressive in its behaviour, because the conception of jihad in this hypothetical case is interpreted in its spiritual and moral sense. This kind of society "is the best we can realistically and coherently - hope for". ${ }^{140}$ Kazanistan is to be considered by liberal peoples as a suitable member of the "confederation of peoples". At this stage Rawls distances himself from his earlier analytical position in $A$ Theory of Justice and Political Liberalism, instead is oriented toward a moral defense of political community. ${ }^{141}$

Rawls' The Law of Peoples warrants serious criticism. One of the criticisms raised in relation to Kazanistan. Rawls certainly is not well aware of the nature of Islamic law or Sharia as applied to Kazanistan (either Pakistan or Saudi Arabia for example). Also, he is ignorant of the ways through which human rights would be systematically violated in this hypothetical example. Nor is he attentive to the fact that rejection of secularism in Kazanistan is the immediate outcome of a genuine belief in the absolute superiority of Islamic law over civil law and regulations, as it is seen in the contemporary Iranian situation. Rawls fails to grasp the gravity of the consequence of not just search for absolute truth, but claims that it is achievable thus licensing and justifying nonrecognition and hence rejection of different others. Once a particular religious belief system is considered to be absolute, the one and only truth, naturally all other variations are simply denied as being wrong paths to divine truth. The biggest problem in this case is that the declared wrong path to truth not only is rejected, but also its followers would be considered as enemy of God, punishable by death. In Kazanistan, there would not be any other choice, except being close-minded to all different others - those who are looking for

\footnotetext{
${ }^{140}$ Rawls, The Law of Peoples, p. 78.

${ }^{141}$ David Fagelson, "Two Concepts of Sovereignty: From Westphalia to the Law of Peoples?" International Politics 38, no. 4 (December 2001): 506.
} 
their own substantive ends. Kazanistan has an prospect for becoming a human rights lawabiding country nor a modern civil society, because it follows the assumed superior divine law logically a fundamental challenge to toleration and recognition of different others.

Rawls might think of a Kazanistan in which there is no commitment to killing and terror, but ignores the fact that even the most peaceful and law-abiding Kazanistan societies - such as Saudi Arabia or Pakistan - stand against modern moral values and institutions of civil society and by implication the law of peoples. Such a hypothetical society, by its nature, cannot recognize and commit to modern values such as religious tolerance, pluralism, and human rights. Kazanistan is a society governed by political Islam, thus has the potential of becoming expansionist. If Islamic law is preferred over democracy, then Kazanistan cannot possess the features of liberal peoples. Then, how is it allowed to enter into the peaceful and democratic "confederation of peoples"? How is it possible for liberal peoples to enter into cooperation with Islamists in Pakistan and Saudi Arabia for example, who believe in the supremacy of their own interpretation of Islam over human rights and fundamental freedoms? Just because societies such as Jordan, Morocco, Lybia, The United Arab Emirates, Qatar, and Kuwait, are non-expansionist, as Rawls mentions, it is hard to claim such societies respect human rights as the principle condition of entering the "confederation of peoples". These are at least some questions left unanswered by Rawls.

Another set of criticism can be levelled against the fundamental criterion of nonaggressiveness in the behaviour of decent societies. One relates to the challenge of precisely defining the criterion of the non-aggressiveness. The idea of membership of decent peoples in a "confederation of peoples" is constructed upon two principles: First, 
human rights should be respected as a necessary condition of the decency of political institutions and the legal order of society. Second, decent society should not behave aggressively. ${ }^{142}$ These two conditions are intrinsically indistinguishable. It is not logical to say that a violator of human rights enters into a confederation because of the criterion of non-aggressiveness. Indeed, there is an inextricable interwoven relation between the two conditions. States deserved to be called aggressive because they are reluctant to accept human rights and allow genuine political participation. Even if some decent peoples such as China, for example, enter into the confederation of the well-ordered liberal societies, this is not because of the criteria depicted by Rawls, for instance, but due to political aspirations, benefit calculation and so on. At least the history of the recent past is a testimony to the lack of any attention to human rights in the cooperation between liberal and non-liberal peoples. The clearest example of this claim is the participation of Iranian high delegation in the inaugurating celebration of the UN Council of Human Rights consisting of Said Mortazavi, the Islamic Republic regime's Chief Prosecutor who has tortured and killed many Iranians among them Zahra Kazemi, an Iranian/Canadian journalist imprisoned there.

Rawls' principle of justice as fairness, as a way of recognition is not immune from criticism either. The point here is that those who are excluded from the peaceful "society of peoples" are the losers. The only way remaining to save them is through the cooperation with liberal peoples. Rawls overlooks the fundamental dimension of the equality of peoples. He ignores the fact that existing global structure undermines the

142 Rawls, The Law of Peoples, p. 80. 
equality of peoples unless it is regulated by principles of distributive justice. ${ }^{143}$ Thomas Pogge has posed severe criticism of this sort. Pogge points out that, in the current world, 13 percent of humankind lives in affluent societies with a per capita GDP of $\$ 30,000$, while 87 per cent live in poor societies with a per capita GDP of $\$ 1,200$. Affluent societies, together control 79 per cent of the global product and enjoy great superiority in bargaining power. ${ }^{144}$ In such terms of the unequal distribution of justice, how can Rawls's veil of ignorance be justified? "Under Rawls' proposal, the global economic order is likely to be skewed against the poorer peoples"; 145 means that Rawls formula in The Law of Peoples fails to provide a working medium for distributive justice. As Pogge argues:

Rawls' utopia is flawed, then by excluding the concern to maintain global background justice, and by excluding any preference for structuring the global economy so that it moderates inequalities and enables especially the economically weakest societies to grow. ${ }^{146}$

However, the criticisms against Rawls should not blind us to the valuable contribution of his work in the development of the literature on recognition. The Law of Peoples exposes a shift away from procedural liberalism toward a highly pluralistic approach respecting although not explicitly recognizing the existing difference between societies. In other words, at the international level, Rawls acknowledges the diversity of societies with their own different identities and traditions of thought This acknowledgment problematizes the assumptions of mainstream International Relations theory, particularly realism. Resting on the moral values of human agency, he challenges the neo-realist idea of the similar functioning of states, and favours distinct incentives in

\footnotetext{
${ }^{143}$ Allen Bauchanan, "Rawls's Law of Peoples: Rules for a Vanished Westphalian World," Ethics 110 (July 2000): 709.

${ }^{144}$ Thomas Pogge, "Rawls on International Justice," The Philosophical Quarterly 51, no. 203 (April 2001): 251.

145 Ibid., p. 252.

146 Pogge, "Rawls on International Justice," p. 253.
} 
the behaviour of states due to their different identities. In addition to this, his categorization of peoples into well-ordered liberals and those of non-liberals, and the optimistic idea that the latter will one day enter into the society of peoples, according to Brown's argument, is a more useful and substantive distinction that exist between democracies and others, or the West vs. the Rest. ${ }^{147}$

Philosophically, the most distinguished feature of his theory concerning the issue of difference is the significance he accords to the notion of reasonableness instead of an instrumental rationality. For him, reasonableness is a notion associated with responsibility and moral willingness of liberal peoples, who cannot be neutral toward the fate of others to take a position. Emphasis on duties to assist with societies burdened by unfavourable conditions and also cooperation with other non-liberal peoples to persuade them to enter into the "society of peoples" reflects the chief value of reasonableness and promotes the moral capacity of human agency. Furthermore, the importance given to moral duty of liberal peoples provokes us to think of a shift from his earlier account towards a kind of definition of human agency, which is portrayed in terms of the communal stand, or as Brown puts it, towards continental Kantian and perhaps Hegelian philosophy. ${ }^{148}$ For this reason, it is evident that, in The Law of Peoples, Rawls shifts towards a highly pluralist approach to normative theorizing of international relations. His emphasis on peoples - with moral commitment toward non-liberal peoples - instead of states, further persuades us to accept his more cosmopolitan position.

From this standpoint, a strong case can be made on his contractarian grounds that different people in the world have a kind of distributive obligation to respect each

\footnotetext{
${ }^{147}$ Pogge, "Rawls on International Justice," p. 23.

${ }^{148}$ Brown, "The Construction of a 'Realistic Utopia': John Rawls and International Theory," p. 19.
} 
other's distinctiveness insofar as the principle of autonomy is not violated. This is the basis for theory in alternative approaches. ${ }^{149}$

\section{Part Two: Acknowledgment of Difference in Alternative Approaches}

It is not surprising to see overlapping arguments conducted against liberal cosmopolitanism between communitarian and critical approaches. These approaches forcefully challenge conventional scholarship as well as the liberal-cosmopolitan's failure to recognize and effectively address the existing cultural and identity differences. ${ }^{150}$ Just as the philosophical sketches among the critics of the individualism of the Enlightenment gave urgency to the understanding of cultural and identity differences - as it is seen, for example, in Herder's cultural pluralism ${ }^{151}$ - the stated approaches are set against both the rationalism of neo-realism and the proceduralism of liberal-cosmopolitanism. To put it another way, the same as the instrumental rationality of the thinkers of the

\footnotetext{
${ }^{149}$ I have borrowed the term 'alternative approaches' as normative theories in the field of international relations from Chris Brown. Brown, International Relations Theory: New Normative Approaches, pp. 1-4. ${ }^{150} \mathrm{As}$ a term mostly used in the philosophy of science, conventionalism refers to the justifiability of theory in bringing order to the known facts, and, also providing concepts and principles for things as yet to be discovered. Conventionalism refers to both natural and social sciences. I borrowed the application of this term in International Relations from Fred Chernoff, The Power of International Theory: Reforming the Link to Foreign Policy Making Through Scientific Inquiry (London: Routledge, 2005) and Fred Chernoff, "Scientific Realism as Meta-Theory of International Politics," International Studies Quarterly 46, no. 2 (2002): 189-207. More precisely, conventionalism in the literature of International Relations refers to positivist assumptions that dominate this field of knowledge. See Nicholas Rengger, "Political Theory and International Relations: Promised Land or Exit from Eden," International Affairs 46, no. 4 (2000): 755-70. Conventionalism, whereby, refers to neo-realism and liberalism. It is also recommended to see Richard Shapcott, "Cosmopolitan Conversation: Justice Dialogue and Cosmopolitan Project," Global Society 16, no. 3 (2002): 221-43. ${ }^{151}$ Isaiah Berlin, The Crooked Timber of Humanity: Chapters in the History of Ideas, Henry Hardy ed. (New York: Vintage Books, 1992), p. 37. This interpretation can also be seen in Berlin, Three Critics of the Enlightenment: Vico, Hammann, and Herder, Henry Hardy ed. (Princeton: Princeton University Press, 2000). Chris Brown also favors the idea that Herder was a revolt against the idea that the richness of the cultural experience could be replaced by the conception of reason endorsed by thinkers of the Enlightenment. See also Chris Brown, International Relations Theory: New Normative Approaches (New York: Columbia University Press, 1992), p. 60.
} 
Enlightenment that ended up in "the iron cage" of individualism, ${ }^{152}$ the rationality of neorealism and the procedural liberalism and cosmopolitanism also yielded a narrow perspective through which only privileged practices and institutions are judged.153 This narrowness is the target of both communitarian accounts and divers strands of critical theory.

The communitarian critics of liberal-cosmopolitan theories of International Relations have grafted the liberal-communitarian debate onto the field of International Relations in order to re-assess the importance of ethical reasoning in that field. Central to this re-assessment is whether the individual or societies are to be the object of international justice, and whether justice is purely a universal distributive term or it is a recognition-based conception. Although the debaters share their commitments to moral obligations among individuals and cultural groups in international practice, they follow different philosophical traditions of the Enlightenment and post-Enlightenment. However, due to the very different philosophical traditions the debaters disagree on the appropriate approaches toward their goals. For example, while Habermas, in part, places his conception of discourse ethics on a definitive procedure of practical reason, Taylor tends to acknowledge the legitimacy of the conception of good society. ${ }^{154}$ On the same

\footnotetext{
152 Weber's evocative term of 'the iron cage' has well been used by Taylor in analysis of the malaises of modernity. See, Taylor, The Ethics of Authenticity, also Steward Clegg, "Max Weber and Contemporary Sociology of Organization," in Organizing Modernity: New Weberian Perspectives on Work, Organization, and Society, Larry J. Ray and Michael Reed ed. (London: Routledge, 1994), p. 50.

${ }^{153}$ Responding to MacIntyre's critique of the Sources of the Self, Charles Taylor refutes a particular account or particular ground for judging morality of the social practices. See Charles Taylor, "Reply to Commentators," Philosophy and Phenomenological Research LIV, no. 1 (March 1994): 203-33. Also Charles Taylor, "A Most Peculiar Institution," in World, Mind, and Ethics: Essays on the Ethical Philosophy of Bernard Williams, J. E. J. Althon ed. (New York: Cambridge University Press, 1995), pp. 132-55.

${ }^{154}$ In A Most Peculiar Institution, Taylor interrogates the procedural notion of the reason according to which agent's thought is judged by "the definitive procedure of practical reason". He argues that Habermas' conception of a discourse ethics is founded, in part, on the same consideration" ... "it is a new and interesting variant of the procedural idea". For Taylor, then, Habermas' ethics is a procedural ethics founded upon one
} 
token, as we see shortly, while Linklater searches for human freedom within the postsovereign institutions and promotes the community of mankind as a cosmopolitan approach, Frost argues that human freedom is to be developed within states and the states system. Nonetheless, both share the idea that normative international relations theory should identify the proper nature of ethical relationships in international relations between individuals, of individuals to states, of states to individuals, and of states to other states. ${ }^{155}$

Recognition of difference has also become the focus of inquiry in critical theories, including Habermasian and Gramscian critical theories and post-foundational poststructuralist/postmodernist accounts. These alternative accounts share with communitarians the idea that due to the positivist bias of mainstream theory and liberalism, distinctive identities have been neglected in theorizing of International Relations. Even though distinctiveness becomes the issue of theorizing, it is reduced to the level of liberal pluralism. In liberal pluralism, different identities are only tolerated instead of being recognized as the substantive components of society. The liberal account of toleration seeks to consciously change one's distinctive definition of the selfhood. It is, indeed, proselytization, which is very different from recognition. Rcognition requires learning to live together in spite of deep differences and disagreements about one

\footnotetext{
basic reason. To read the details of the critic of his account see: Taylor, "A Most Peculiar Institution", pp. 132-55. Glen Lehman also argues that Habermas gives the greatest importance to procedure in political and economic life. See Glen Lehman, "Globalization and the Authentic Self: Cosmopolitanism and Charles Taylor's Communitarianism," in Global Society 16, no. 4 (2002), pp. 419-437. Also see: Jürgen Habermas, "From Kant to Hegel and Back again - The Move towards Decentralization," European Journal of Philosophy 7, no. 2 (1999): 129-57; and Charles Taylor, "Comment on Jürgen Habermas' 'From Kant to Hegel and Back Again," European Journal of Philosophy 7, no. 2 (1999): 158-63.

155 Molly Cochran, Normative Theory in International Relations: A Pragmatic Approach (Cambridge: Cambridge University Press, 1999), p. 7.
} 
anothers' distinct belief and identity. ${ }^{156}$ More particularly liberalism refutes the thick conception of culture, hence ignores the demands for recognition of identity and culture distinctiveness. Such ignorance might amount to abandonment, mistreatment, and even non-recognition of distinct others as right holders.

However, among the alternative theories, critical theory has grown more rapidly and has become a substantive position from which strands of critical international theory can be developed. ${ }^{157}$ In this regard also, Habermasian account, because of its concerns with ethical consideration has been particularly attractive for normative thinkers of international relations than Gramscian account that was mainly concerned with issues of political economy. ${ }^{158}$ However, central to critical theory is a strong will for the emancipation of mankind. But, as opposed to post-foundational accounts, critical theory launched the project of emancipation from an emphasis on rational autonomy of action as foundational truth, hence became the important resource available in developing critical international theory. However, the problem with critical theory, as will be explained below, is that it does not take the conception of recognition as the key factor in identity. ${ }^{159}$ Nor does it give a workable theory for the recognition of difference.

\footnotetext{
${ }^{156}$ For a good reading of the difference between the tolerance and recognition from the perspective of Taylor see: Jean Bethke Elshtain, "Toleration, Proselytization, and the Politics of Recognition: The Self-Contested," in Charles Taylor, Ruth Abbey ed. (Cambridge: Cambridge University Press, 2004 ), pp. 127-139.

${ }^{157}$ Brown, International Relations Theory: New Normative Approach, p. 201.

${ }^{158}$ Neta Crawford, Argument and Change in World Politics: Ethics, Decolonalization, and Humanitarian Intervention (Cambridge: Cambridge University Press, 2000); Thomas Risse-Kappen, "Let's Argue! Communicative Action in World Politics," International Organizations 54, no. 1 (2000): 1-39.

${ }^{159}$ Since the righteousness of actions and thoughts in the modern world are justified by referring to the consent at the bottom of social relations (in liberal conception of contractarian theory), what makes people different is ignored. Rather, due to proceduralism of contractarian theory, identity difference is assimilated, marginalized, or excluded. That is the reason why it is claimed that recognition of difference is the determinant factor in addressing the question of 'who I am' at the individual level, or who we are at the group level of identity.
} 
Arguably, the question of how distinct identities have been developing within their own historical and cultural background differently has been addressed in a variety of theoretical orientations. In this regard, critical theory advances the acknowledgment of different takes on the historical analysis of culture and identity as the starting point of theorizing. Having an emancipatory thrust in orientation, critical theory is also concerned with the question of how equal value of different individuals and distinct cultures should be acknowledged. Critical theory differs from Taylor's account of recognition on the conception of emancipation. For example, critical theory begins with criticizing the positivist assumptions of mainstream neo-realism theory, whilst the Taylorian account interrogates normative liberal theory. Going deeper into philosophical foundations, critical theory takes differentiations in identity as a given and then, as seen in Habermas, endorses a communicative account of reason to overcome the constrains pertaining to their reconciliation. In contrast, Taylor starts with recognition as the crux of identity formation. This point of difference, I argue, can be a distinctive source in normative theorizing of international relations. The immediate advantage of Taylorian account is that it aspires to release normative theory from the dogma of the prevailing liberal normative account asserting that different cultures should get their own ways of life through a single and overarching simplified view. Indeed, Taylorian account advances a re-articulation of liberalism in light of the whole historical process as an organic whole:

Each form of human perfection then, is, in a sense, national and time-bound and, considered most specifically, individual. Nothing develops, without being occasioned by time, climate, necessity, by world events or accidents of fate. ${ }^{160}$

\footnotetext{
160 Johann Gottfried von Herder, Yet another History of Philosophy, F. M. Barnard trans. (Cambridge: Cambridge University Press, 1969), p. 191.
} 


\section{Cosmopolitan/Communitarian Debate and Questions of Difference}

Although cosmopolitan/communitarian debate has its roots in the Kantian/Hegelian philosophical traditions, this debate has recently become one important source of reflection in International Relations Theory. One of the works, which is often cited as the beginning of debate in International Relations is Michael Walzer's Just and Unjust Wars in which great importance is given to moral reasoning in the discipline. ${ }^{161}$ For Walzer, moral values are not statements of preference, rather they are manifestations of ethical questions about "what ought to be done in particular concrete circumstances". ${ }^{162}$ From a communitarian perspective, this "ought to be" is to be regarded as the central tenet in the depiction of the idea of international justice.

In brief, dispute the liberal/cosmopolitan focus on the asocial conception of the self. This portrayal of the self is steeped in liberal perspective no matter the cultural and historical circumstances with which one identifies oneself in communal practices and traditions. If the self is socially embedded, and individuals flourish within a social context of common values, then community must have some sort of moral worth prior to the worth of the abstract individuals. The communal worth, in this sense, turns into valuing the nation and nationhood as the source of theorizing of International Relations. In addition, communitarians criticize the liberal preference for procedural right over the substantive ideas of justice. In international thought, it is the state to promote justice. If individuals are socially embedded and community holds the highest value in the life-

\footnotetext{
${ }^{161}$ In order to see Walzer's contribution in normative debate in International Relations following works are cited: Michael Walzer, Just and Unjust Wars (New York: Basic Books, 1977); Michael Walzer, Thick and Thin: Moral Argument at Home and Abroad (New York: University of Notre Dame Press, 1994); and Michael Walzer, "The Moral Standing of States," in International Ethics, Beitz et. al. ed. (Princeton: Princeton University Press, 1985), pp. 217-237.

${ }^{162}$ Brown, International Relations Theory: New Normative Approaches, p. 10.
} 
world, it would not be plausible to advocate any conception of universalism. Instead, particularism must be seen as the origin of reflection in political life. It is not then surprising that Rawls' Theory of Justice, representing a liberal theory of justice employing a rationalist and individualist methodology, has become the primary target of communitarians. From the 1980 s, the literature of international relations has represented communitarianism as a normative movement against liberalism.

The quarrel between the two normative traditions of thought and their impact on the theory of International Relations continued in 1980 s and after. During this time, Walzer, Alasdair MacIntyre, ${ }^{163}$ Michael Sandel, ${ }^{164}$ and Charles Taylor discredited further asocial and atomistic conceptions of the self, promoted by analytical accounts of individualism and especially Rawls. Their attempts undoubtedly prompted international thinkers to incorporate the importance of transformations of political communities in the aftermath of the Cold War into their study. Further, the context in which knowledge is intersubjectively produced and interpreted became a sharpened focus of study. In light of this transformational observation in the study of international relations, the question of whether normative theorizing should be neutral toward ontological and cultural differences and hence advance only a distributive approach to justice became the central theme of study. Indeed, controversy over the historical and cultural ties with particular

\footnotetext{
163 Macintyre' works has tacitly been referred to as one of the communitarian sources of inspiration in the field of International Relations. Some of these citations are as follow: David Morrice, "The LiberalCommunitarian Debate in Contemporary Political Philosophy and its Significance for International Relations," Review of International Studies 26 (2000), pp. 233-251; and Thomas Scott, "Thinking Religious Cultural Pluralism Seriously; The Global Resurgence of Religion and the Transformation of International Society," Millennium: Journal of International Studies 29, no. 3 (2000): 815-841.

164 Michael Sandel is known as one of the communitarian political thinkers, but has not been cited as an influential figure in the field of International Relations. For reviewing his communitarian account see Michael Sandel, Liberalism and the Limits of Justice (Cambridge: Cambridge University Press, 1982); and Michael Walzer, Spheres of Justice (Oxford: Basil Blackwell, 1983).
} 
community urged the communitarian thinkers to take the conception of justice in a more concrete sense by which respect for the values of diverse communities are held. In the field of International Relations these insights paved the way for important ontological observations about the construction and evolution of social realities. ${ }^{165}$ Since communitarian insight portrays social institutions as the products of intersubjectively constructed identities and practices, it can somehow acknowledge the importance of difference and its recognition in the study of international relations.

However, since the most obvious points of controversy between the liberals and communitarian thinkers are related, respectively, to community, identity, and the universal/particular dichotomy, I will explain them in further detail to clarify how these themes affect the question of difference in the theorizing of International Relations.

The politics of community has been raised as a response to the negative social effects of the liberal ontology of the individual which prefers self-interest as opposed to the common good and communal values. The destructive effect of such an unencumbered notion of the self has provoked a group of communitarians to emphasize the importance of social cohesion, responsibility, and community for the sake of social order. This sense of community conveys a normative ideal suggesting a harmonized link between social responsibility and individual freedom, which ties up individual life with the common good of society out of which identity is constructed. This suggestion, indeed, discredits the neoliberal view of individualism and the logic of the market that disregards social cost, as seen in the case of Britain and American economic policies in the time of Thatcher and Reagan. Therefore, communitarians tend to promote individual freedom in light of social

\footnotetext{
165 Stefano Guzzini, "A Reconstruction of Constructivism in International Relations," European Journal of International Relations 6, no. 2 (2000): 147-82.
} 
context and community. The reason for this claim, as Charles Taylor puts it, is that community would not exist if the social goods are victimized for the sake of empty individual freedom. ${ }^{166}$

Stepping into the domain of International Relations, communitarians advance the idea that in international sphere, priority must be given to the integrity and independence of groups, communities, and states as well as the context in which values and meanings are shared. ${ }^{167}$ This idea derives from a communitarian account of the priority of social life and communal values over individual rights. For them, as opposed to cosmopolitans like Beitz, who favours nationally transcended standards of justice beyond nations, if morality and justice are developed without national specification, they would lose their meaning. As a consequence, cosmopolitan justice becomes a hollow concept. Mervyn Frost argues, for example, that political community is composed of individuals, hence, they "come to self-consciousness appreciation of the way in which they constitute the whole". ${ }^{68}$ Etzioni also favours a vision of the world order that features a true global community rather than the existing international relations which is based on political coercion. ${ }^{169}$ In light of these observations, a favourable life-world is the one in which communal and moral values are counted. Within "global community" the conception of sovereignty reflects a deep and committed responsibility to construct a good society in which most people, most of the

\footnotetext{
166 Taylor, “Cross-Purposes: The Communitarian Debate," p. 183.

167 Emanuel Adler, Communitarian International Relations (London: Routledge, 2005), pp. 98-116; and Emanuel Adler, "Cognitive Evolution: A Dynamic Approach for the Study of International Relations and Their Progress," in Progress in Postwar International Relations, Emanuel Adler and Beverly Crawford, ed. (New York: Colu mbia University Press, 1991), pp. 43-88.

168 Mervyn Frost, Ethics in International Relations: A Constitutive Theory (Cambridge: Cambridge University Press, 1996), p. 149.

${ }^{169}$ Amitai Etzioni, From Empire to Community: A New Approach in International Relations (New York: Palgrave Macmillan, 2004), pp. 234 and 20-22
} 
time, are able to go about their lives and participate in public life without any fear. ${ }^{170}$ From an ideal perspective, in the adjusted world order people are considered as both the source and the subjects of the discourse of life.

Accordingly, communitarians discredit the individualist base of social relations arguing that individual identity is constructed by the community in which (s)he lives, and "finds meaning in life by virtue of his or her membership of a political community". ${ }^{171}$ The validity of the concept of the self derives from the fact that individuals are encumbered by communal ties. Challenging liberal vision on the hypothetical priority of individual over society, Walzer favours a conception of the self that is historically contingent and socially constructed. For Walzer, the conception of international justice should be incorporated in a historically specified individual. He calls such a conception of self as thick; a conception which promotes pluralism. "Thick, divided selves are the characteristic products of, and in turn require, a thick, differentiated and pluralist society".172 Charles Taylor also argues that "man is a social animal, because he is not self-sufficient alone, and in an important sense is not self-sufficient outside a polis". ${ }^{173}$ Grafting the communitarian account of the self onto the field of International Relations, Etzioni crafts a neo-communitarian approach, whose dialogical essence admits reconciliation among the conflicting principles. That is to say, in his conception of global community not only the universal

\footnotetext{
${ }^{170}$ Amitai Etzioni, Security First: for a Muscular, Moral foreign Policy (New Haven: Yale University Press, 2007), p. 2.

${ }^{171}$ Brown, International Relations Theory: New Normative Approach, p. 55.

172 Walzer, Thick and Thin, p. 101.

${ }^{173}$ Charles Taylor, "Atomism," in Philosophy and Human Sciences: Philosophical Papers II (Cambridge:

Cambridge University Press, 1985], p. 190.
} 
principles must apply but also particularistic conceptions of the good life by different nations ought to prevail, without ever taking precedence as a matter of principle. ${ }^{174}$

Neo-communitarian thinkers, then, expose an enthusiasm to carefully advance a balance between the Western vision of individual autonomy and the Eastern idea of normatively controlled social order. Accordingly, the context which admits discrimination among different visions of the good life must be changed if patterns of exclusion and oppression must be overcome. By the same token, in international scope, neocommunitarians argue that both the Eastern account of autonomy which might disregard social designs and the Western tendency to promote only autonomy without regard to the foundations of the social order must be reconciled in favour of a responsible global community, if discrimination, exploitation, and exclusion are to end.

To sum up, by promoting a contextualized conception of identity in the politics of community, communitarianism has succeeded in highlighting some weaknesses of normative liberalism. More importantly, communitarians have advanced the importance of a particular social identity as the most central theme in normative International Relations theory. The communitarian strands of either political theory or International Relations then conclude that justification of political principles would be restricted to cultural and moral values of particular communities. Consequently, the application of the atomistic account of individualism leads to unfavourable social consequences, which might destroy the specific culture and moral values of those communities. Extending this conclusion to the context of world politics, atomistic policies ignoring particular characteristics of individual nations disregard the notion of international community with

\footnotetext{
${ }^{174}$ Amitai Etzioni, "A Neo-Communitarian Approach to International Relations: Rights and the Good," Human Rights Review 7, no. 4 (July-September 2006): 79.
} 
its web of moral obligations ${ }^{175}$. The immediate result of such ignorance is that a particular culture tends to dominate other societies. Triggering the "blind-eyed" characteristic of procedural liberalism, communitarians favour a conception of the life-world that respects plurality of values.

In spite of highlighting the importance of difference in International Relations theory, the communitarian approach is not immune from criticism. For example, the communitarian idea that individuals are first of all citizens than human beings is severely criticized by liberal counterparts. That is to say, before being shaped by their particular social values and communal requirements, they are human beings similar to all fellow human beings. Individuals are more importantly the members of a society of mankind than particular societies. ${ }^{176}$ Communitarianism, in this way, threatens the dignity of human beings and challenges the fundamental equality of all human beings. In addition, it can be learned from communitarian theory of the encumbered conception of the self that there are no universal principles of humanity upon which our moral judgment can be grounded. Attachment to particular social and cultural values by citizens also makes citizens reluctant to move beyond their particularistic values. Therefore, we do not know, for example, how to judge the behaviour of those citizens or cultural groups and even some states might never tend to respect the principle of humanity and hide behind the shelter of cultural specifications.

The question is, therefore, whether there are grounds for a reconciliatory alternative theory in combining cosmopolitanism and communitarianism, or linking together the universalism of the principle of humanity and the particularism of different

\footnotetext{
175 Morrice, "The Liberal-Communitarian," p. 241.

176 Ibid., pp. 242-43.
} 
identities in distinct contexts. For me, the answer lies in the areas in which philosophy comes to be the intellectual context in theorizing international relations. Intellectual context is persuasive, because as Chris Brown argues, a free-standing academic discipline of international relations would not be capable of providing an adequate account of how things hang together. ${ }^{177}$ Arguably, the quest for a reconciliatory mode of theorizing addressing the moral dichotomy between universalism and particularism has partly turned into a relativist way. This relativist turn is the theme of my brief investigation in following sub-section.

\section{Differences in Post-Foundationalist Perspectives}

Post-foundationalism seeks to deconstruct the grounds of positivist knowledge of the discipline of International Relations and aims at embracing multiple voices and perspectives, and consequently provides additional space in which the issues that currently comprise the subject matter of the field be thought about. ${ }^{178}$ These accounts draw inspiration from the French poststructuralist thought of, primarily, Michel Foucault and Jacques Derrida as well as the postmodern thought of Jean-Francois Lyotard, Jean Baudrillard, Emmanuel Levinas, and Paul Virilio. ${ }^{179}$ Investigating how these figures deal with the issue of difference is a philosophical investigation and is not easy task to undertake in this writing, because post-foundationalist thinkers listed above have

\footnotetext{
${ }^{177}$ Brown, International Relations Theory: New Normative Approaches, p. 77.

178 Richard Devetak, 'Postmodernism', in Theories of International Relations, Scott Burchill, et al., ed. (New York: St. Martin's Press, 1996), pp. 161-187; George and Campbell, "Patterns of Dissent and the Celebration of Difference: Critical Social Theory and International Relations," International Studies Quarterly 34, no. 3 (1990): 269-294; Richard Ashley, "The Achievement of Post-Structuralism," in International theory: positivism and beyond, Steve Smith, Ken Booth and Marysia Zalewski ed. (Cambridge: Cambridge University Press, 1996).

${ }^{179}$ To read French post-structuralism see: Glyn Williams, French Discourse Analysis: The Method of PostStructuralism (London: Routledge, 2007).
} 
adopted different intellectual routes to question difference ${ }^{180}$. But, the general point in their approach is to severely challenge the intellectual foundations of the Enlightenment, and for this reason they are hostile to the idea of rationality, social progress or human emancipation, stable meanings, meta-narratives, and claimed universal rational scientific truth. Specifically, social truth for post-foundationalist thinkers is neither given nor purely rational, rather it is subject to an open-ended comprehension of history of the past and the context. This last claim has resulted in serious doubt about the finality of a meaningful world. According to such doubt our life-world is surrounded by competing plurality of values and realities. Hence, not only rationality, meaning, history, but also moral values are subject of contextual interpretations of a constantly changing and contingent plural world. ${ }^{181}$ In such frame of mind, the only acceptable proposition in our life is the contingency of difference. As Michael Shapiro states:

Insofar as 'social reality' emerges in various writing genres, investigation of how the world is apprehended requires inquiries into various pre-texts of apprehension, for the meaning and value imposed on the world is structured not by one's immediate consciousness but by the various reality-making scripts one inherits or acquires from one's surrounding cultural/linguistic condition.182

Post-foundationalist theorists have employed a variety of post-scientific methods and theoretical approaches to challenge conventional scholarship. These methods span from deconstruction and genealogy of knowledge to hermeneutics all aiming at

\footnotetext{
${ }^{180}$ This sub-section has been written by reading of Chris Brown's works including: Brown, International relations Theory, New Normative Approaches; Chris Brown, "Critical Theory and Postmodernism," in Contemporary International Relations Theory, A.J.R. Groom ed. (London: Pinter Publishers, 1994); Chris Brown, "Turtles all the Way down: Foundationalism, Critical Theory and International Relations," Millennium Journal of International Studies 23, no. 2, (1994): 213-236. Also Cochran, op. cit. chapter 4. 181 Keith Jenkins, "Why Bother with the Past?" Rethinking History: The Joumal of Theory \& Practice 1 (1997): 56-66.

${ }^{182}$ Michael J. Shapiro, "Textualizing Global Politics," International/Intertextual Relations, James Der Derian and Michael Shapiro ed. (Washington D. C.: Lexington Books, 1989), p. 11. Also see: Michael Shapiro, Reading the Post-Modern Polity (Minneapolis: University of Minnesota Press, 1992).
} 
questioning the truth claims of modernity. ${ }^{183} \mathrm{~A}$ point of clarification is needed here. The post-foundational methods are being employed to interpret historical truth in such a way as to open a new window through which others are included. This is possible by the deconstruction of the dogma of the privileged status of Western thought that excludes the others from the discourse. Hence, history is interpreted as a series of narrations: "like everything else" history "becomes simply a collection of signs available for play". ${ }^{184}$ Within this perspective, historical events of the last few decades are seen as true modes of Western domination over the world. Referring to the neo-realist assumption that balance of power serves a kind of equilibrium in the international order, both affirms western domination and cast it as the absolute truth of history in Western culture.

A historical domination could interpret itself as universal and absolute, as long as it could believe that the future would prove it such; the universality of the western mode (the absoluteness of western domination) seemed indeed merely a matter of time. The ground for certainty and self-confidence could not be stronger. 185

With incorporating the post-foundational insights into the field of International Relations, the very notion of truth, reality, and structure, which are fundamental concepts in International Relations Theory lose their meaning. ${ }^{186}$ Post-foundationalism's call for revisiting disciplinary verities from the 1990 s have challenged almost all reigning orthodoxies on the international order, state, sovereignty, and nationalism as well as

\footnotetext{
${ }^{183}$ To see the detail of anti-method practices of anti-foundational approaches look at: Meynell A. Hugo, Postmodemism and the New Enlightenment (Washington: The Catholic University of America Press, 1999). ${ }_{184}$ Philip E. Simmons, Deep Surfaces, (Athens: The University of Georgia Press, 1977), p. 9. 185 Bauman, Intimations of Postmodernity, p. 96. ${ }^{186}$ Richard Ashley, William Connolly, David Campbell, Jim George, Michael Shapiro, James Der Derian, Michael Dillon, Simon Dalby, Bradley S. Klein, and Timothy W. Luke are the key anti-foundationalist theorists not only have radically challenged the intellectual foundations of conventional scholarship, but also contributed extensively to a new post-structuralist and postmodern international relations theory. They have also, by and large, highlighted the concep tion of difference.
} 
related identities, values, and interests. ${ }^{187}$ Postmodern feminist, Spike Peterson, for example, contests the adequacy of the conventional construction of political identity and rationality in the field and argues that these notions are not categorical, but rather they are all contingent practices. ${ }^{188}$ Furthermore, the key dichotomous conceptions of sovereignty - either referring to state, individuals, or sovereignty of truth - and the outside-inside, depth-surface, us-them, and identity-difference practices are disputed.189 Based on such a radical falsification of the positivist assumptions, a variety of the theories of international relations - international political economy, realism and neo-realism, game theory, inter-dependency model, integration theory, rational actor models, and also liberal accounts - all came under serious questioning. Instead, justification of the authenticity of identity and the equality of cultural difference becomes more meaningful. ${ }^{190}$

Post-foundationalism treats the issue of difference in various ways. ${ }^{191}$ I begin with the approach that justifies authenticity of identity difference via celebration of "equality" instead of a "hierarchy" of difference. The latter has been promoted by practicing the

${ }^{187}$ Look at Siba N. Grovogui, Beyond Eurocentrism and Anarchy, Memories of International Order and Institutions (New York: Pargrave Macmillan, 2006).

${ }^{188}$ Spike Peterson, "Whose Rights? A Critique of the 'Givens' in Human Rights Discourses" Alternative XV (1990): 303-44; and Spike Peterson, "Transgressing Boundaries: Theories of Knowledge, Gender and International Relations," Millennium Journal of International Studies 21, no. 2 (1992): 183-208.

${ }^{189}$ In order to read in a further detail about the importance of anti-foundationalism in in ternational relations see for example: James Der Derian ed., Critical Practices of International Relations: Selected Essays (New York: Routledge, 2009); Michael W. Doyle ed., New Thinking in International Relations (Colorado: Westview Press, 1997); Mathias Albert and Yusef Lapid, "On Dialectic and IR Theory: Hazards of a Proposed Marriage," Millennium Journal of International Studies 26, no. 2, (1997): 403-415.

${ }^{190}$ For example Connolly and Ashley advance the idea of a de-centered world, where there is no permanent grounds by which the theoretical assumptions of mainstream international relations is justified. If there is no such grounds, then the conception of sovereignty, territoriality and totality are dismissed. See: William Connolly, Identity/Difference: Democratic Negotiations of Social Sciences (Ithaca: Cornell University Press, 1991); And Richard Ashley, "Untying the Sovereign State: A Double Reading of the Anarchy Problematic," Millennium Journal of International Studies 17 (1988): 227-62.

${ }^{191}$ For a deep analysis of the issue of difference in anti-foundational accounts see: Jim George and David Campbell, "Patterns of Dissent and Celebration of Difference: Critical Social Theory and International Relations," International Studies Quarterly 34 (1999): 269-93. 
dominant superior/inferior relationship in Western thought through which non-Western people have been defined as "the other". The result of such a practice is "the acquisition of an aura of superiority for Western cultures and an imposition of a sense of inferiority upon non-Western ones". ${ }^{192}$ This privileged status of Western thought directed toward the exploitative and colonial actions is the primary challenge of post-foundationalism. ${ }^{193}$ This challenge rests on the principal foundation of modern thought i.e. the focus of the Enlightenment on individualism and the individualization of social affairs. The challengers of the Enlightenment project begins from the very Western conception of individualism stating that the sense of "otherness" has been imposed on non-Western people in order to make a discourse of race excluding them from the dominant culture or society. ${ }^{194}$ Therefore, there is no such thing as an inferior "other". Nor is there any validity to given dichotomy of West/Rest. ${ }^{195}$

If one realizes that every person, group, or nation views a given situation differently, how is one to accept that truth claimed by dominant international relations? This is a timely question especially when one is informed by one's connection with different others by the means of information revolution and globalization. Since one is empowered to know about other cultures and identities all around the world, and discovers how one's truth cannot be precisely the truth of others, the authority of the

${ }^{192}$ Kenan Malik, "Universalism and Difference in Discourse of Race," Review of International Studies 26 (2000): 156.

${ }^{193}$ See Roxanne Doty, "Desires all the Way Down," Review of International Studies 26, no. 1 (2000): 137-39.

194 In Orientalism, Edward Said argues that the conception of 'otherness' and the exclusivist policies deriving from this conception are the products of the Enlightenment's universalistic perspectives that tend to exercise power over the 'other'. This idea means that the West/Orient binary opposition was constructed by those who benefited from this opposition. This binary is the product of a power relationship and is based upon absolute hegemony. It is based on a profoundly historical discourse that strengthens Western culture and imprisons the 'other'. For Said, a European, by virtue of being European, must necessarily be racist in imagining a non-European as 'other' who does not deserve recognition, except recognition as 'other'. See Edward Said, Orientalism (London: Routledge \& Kegan Paul, 1978), pp. 132-34.

195 Kenan, pp. 156-60. 
dominant discourse comes into serious doubt. Nor is it also convincing that there is no escape from pre-fixed Western representation. ${ }^{196}$ Rob Walker highlights this fact arguing that a lack of attention to equality of difference is the main problem in international relations. Postcolonialists have also contributed to the enrichment of the literature developed to falsify the Western representation of identity, more particularly the vision of non-Western nations as others. They, show how the interpretation and historiography of the world order as a dichotomy of the West/Rest is an imaginary construction by Westerners. ${ }^{197}$ Therefore, the outlook which ignores different "others" should be regarded as the source of exclusion and oppression. ${ }^{198}$

The second way to stipulate the centrality of difference in post-foundationalist International Relations Theory is the idea that a "value-free" social approach towards international is not realistic. The reason for this claim is that the positivist theories of international relations fail to include "others" in its theorizing. The conventional scholarship, indeed, reflects a misleading objectivism in international relations resulting in a certain kind of self-fulfilling prophesy that according to Vasquez disregards the

\footnotetext{
196 In order to read the impact of the information revolution on the formation of mass-culture and the way through which post-structuralist assumptions are promoted see: Philip E. Simmons, Deep Surfaces, (Athens: The University of Georgia Press, 1977).

${ }^{197}$ See for example: Dipesh Chakrabarty, Provincializing Europe: Postcolonial Thought and Historical Differences (Princeton: Princeton University Press, 2000); Walter Mignolo, Darker Side of Renaissance: Literacy, Territoriality, and Colonialization (Ann Arbor: University of Michigan Press, 1995); Wang Ning, "Orientalism versus Occidentalism?" New Literary History 1, no. 28 (1997): 57-67; and Fernando Coronil, "Beyond Occidentalism: Toward Non-Imperial Geo-Historical Categories," Cultural Anthropology 2, no. 1 (1996): 51-87.

198 Rob R. B. J. Walker, Inside/Outside: International relations as Political Theory (Cambridge: Cambridge University Press, 1993), p. 77. Also, in the reading of Linklater's Transformation of Political Community, Walker high lights the issue of difference. See: Rob R. B. J. Walker, "The Hierarchicalization of Political Community," Review of International Studies 25 (1999): 154. The idea of difference from view point of Walker can also be read in following works: Rob Walker, "State Sovereignty and the Articulation of Political Space/Time, Alternatives 20, no. 3 (Winter 1991): 445-61; Rob Walker and Saul H. Mendlovitz ed., Contending Sovereignties: Redefining Political Community (Boulder: Lynne Rienner, 1990).
} 
freedom of human beings. ${ }^{199}$ In the same way, Cochran shows that mainstream theory has been constructed upon the fixity of boundaries and the sovereign entities by which a selfsufficient and unproblematic reading of meanings of international history has been promoted. She then concludes that identity is constructed through modes of domination. ${ }^{200}$ For Smith, such domination derives from a Western/white/male/conservative view of international relations in which there is no place for ethnicity, gender, or the problems of the Third World. ${ }^{201}$

The third way to acknowledge the conception of difference in post-foundational accounts is to rearticulate social totality in favour of an appreciation of difference in International Ethics. Social totality presents itself as the recognizable bases upon which knowledge is grounded. Standing at the centre of totality is the foundational basis of truth, which has originated from the thought and experience of Western-derived discourse. Indeed, totality refutes the fact that a structural system is limited, which is to say that it is surrounded and affected by other factors and hence cannot constitute a founding totality. ${ }^{202}$ By refuting such a basis, post-structuralism denies the success of foundationalism in resolving the question of difference within the totality of International Ethics. The reason for this claim is that foundationalist ethics keeps different others within a hierarchy of superior over inferior, and by which the elimination of different others. ${ }^{203}$

\footnotetext{
199 Vasquez, p. 223.

${ }^{200}$ Cochran, op. cit, p. 125.

201 Smith and Booth, op. cit, p. 15.

${ }^{202}$ Ernesto Laclau, "The Political and Impossibility of Society," in Post-Foundational Political Thought:

Political Difference In Nancy, Lefort, Badiou And Laclau, Oliver Marchart, ed. (Edinburg: Edinburg University Press, 2007), pp. 134-153.

${ }^{203}$ Brown, "Turtles all the Way down," p. 229.
} 
Accordingly, post-foundationalism advances an ethical account which is more accurate in addressing the contingent world of plurality and difference. Connolly, for example, promotes an "agnostic ethics of care". Ashley and Walker offer an "ethics of marginal conduct" that conduct questions territorialized ethics and, promotes freedom and democratic practices by listening, questioning and speaking to one another. ${ }^{204}$ Campbell identifies the distinctiveness of identities by referring to different social conditions and suggests the importance of interdependence between those differently formed identities. ${ }^{205}$ It seems that the interconnection between distinct identities constitutes the foundation of international ethics. As Der Derian suggests it can be constructed via particular interconnection and intersubjectively. The ethics he offers derives from the interdependency of caring and responsibility: "An ethical way of being emerges when we recognize the very necessity of heterogeneity for understanding ourselves and others" (Emphasis in original text). ${ }^{206}$ Fiona Robinson's notion of "ethics of care" resembles Der Derian and Campbell. From a feminist perspective, her ethics of care resembles a practical philosophy that acknowledges responsibility and recognition of equality and difference..$^{207}$

In conclusion, in spite of differentiation, post-foundational accounts, more than communitarian perspectives, have highlighted the importance of difference in

\footnotetext{
204 Coch ran, op. cit, pp. 132-33.

205 David Campbell, "The Politics of Radical Interdependence: A Rejoinder to Daniel Warner," Millennium: Journal of International Studies 25, no. 1 (1996): 131. Also David Campbell, "Political Excess and the Limits of Imagination," Millennium: Journal of International Studies 23, no. 2 (1994): 365-75. In order to see Campbell's critique of the state-centric field of international relations see David Campbell, "International Engagements: The Politics of North American International Relations Theory," Political Theory 29, no. 3 (June 2001): 432-48.

${ }^{206}$ James Der Derian, "Post-Theory: The Eternal Return of Ethics in International Relations," in New Thinking in International Relations, p. 58.

${ }^{207}$ Fiona Robinson, "Globalizing Care: Ethics, Feminist Theory, and the International Relations," Alternatives: Social Transformation and Humane Governance 22, no.1 (1997): 122-23.
} 
International Relations. This importance results from the adversarial radical challenge of the intellectual foundations of the Enlightenment advancing a universal discourse in accordance with the idea of the sameness of human beings. The universalistic claim of the Enlightenment's rationality came to be temporalized and localized as a result of which another historical construct was purposefully enlisted to define the life-world. ${ }^{208}$ The rationality of the Enlightenment was replaced with a plurality of a contingent world and difference. Post-foundationalism also stipulates that the discourse of the Enlightenment has advanced a privileged Western conception of the self in a higher state to the "inferior others". Challenging this hierarchy of difference, post-foundationalism appreciates the equality of difference and an adequate international ethics addressing such differences. As mentioned at the end of the previous sub-section, post-foundationalism fails to search for an ethics of equal entitlement for those who distinctively interpret their own values. In sum, post-foundationalism cannot answer how the contribution of different cultures in an ethical discourse can be recognized.

Critical theorists, especially Habermas - and his followers - who provided a point of departure from anti-foundationalism address such failure. Habermas provides a humanist and essentialist framework loyal to the emancipatory idea of the Enlightenment by considering Enlightenment as an incomplete project. By humanist framework, I mean an ethical insight which is concerned with the hope of the marginalized people for being emancipated from historically constructed oppressive social contexts.

${ }^{208}$ Grovogui, op. cit, p. 49. 


\section{Critical International Relations Theory and the Appreciation of Difference}

The question of how to reconcile the universality of moral values with ethical life in which identity is formed intersubjectively is the starting point in understanding of critical theory. In developing a reconstructed account of rationality applying to both the individual and societal levels, and searching for a universalistic conception of morality in which the rights of different others are acknowledged, critical theory has become a leading intellectual project in the study of international relations. Critical International Relations Theory searches for a humanization of the life-world in which human freedom across world society is attained ${ }^{209}$. Project of humanization works, however, if it is grounded on the basis of the idea of emancipation and inclusion.

Admittedly, Critical Theory benefited from the Habermasian response to the crisis of the post-national public sphere in advancing a meaningful linkage between the structures of identity and cultural context ${ }^{210}$. Habermas' efforts have had a great importance in depicting a critical theory of recognition. He rightly assumes that the emancipatory promise of the Enlightenment has not been actualized. In this respect, he blames two issues: first, the higher status given to European modes of thought and its scientific method; and second, the capitalist system, which has distorted the bases of the Enlightenment's emancipatory promise resulting in a vast gap between those promises

${ }^{209}$ Andrew Linklater, "The Problem of Community in International Relations," Alternative 15 (1990): 7.

${ }^{210}$ This linkage is very similar to Giddens' structuration theory. There is also a certain similarity in Habermas' statement of identity with that of Taylor's account of asserting that one is a self-interpreting being who interprets one's world by self-reflection and, thus, self-interpretation. Interpretation of oneself and the life-world take place within the network of interlocutors. For Taylor, such a network is the source of self-interpretation, social conceptualization, and judgment about good and evil, right and wrong. In the same way, Habermas argues that scientism and positivism produce irrational meaning and hence distort self-interpretation. See: Jürgen Habermas, Knowledge and Human Interests, Jeremy Shapiro trans. (Boston: Boston Press, 1968), pp. 68-69. Also see: Jürgen Habermas, Structural Transformation of the Public Sphere: An Inquiry into a Category of Bourgeo is Society, Thomas Burger trans. (Cambridge: MIT Press, 1989). 
for emancipation and socio-political context ${ }^{211}$ Relying on the practical thrust of the conception of reason, and trying to contextualize it, Habermas tends to reconstruct a notion of reason that is not restricted within the confine of instrumental rationality. Instrumental rationality employed in scientism, as stated above, amounts to a distortion of self-interpretation leading to an exclusivist vision to diversity of human values.

Arguably, in advancing a reconstructed account of reason, Habermas steps back to the advantage of the ancient philosophy in appreciating diversity in human values. Approaching Aristotle's account of practical reason, where rationality is tied to the virtuous habits of citizens within political context, Habermas takes a practical tone of contextualized rationality as the grounds for his reconstruction. This practicality of reason is grounded upon practical intentions, which cultivate virtuous behaviour among citizens. Such an assertion of reason fits within Kantian language of practical reason out of which the "good will" of rational beings becomes the base of political ethics. ${ }^{212}$

This conception of reason evidently moves towards an unlimited notion of the social good. In this account, individual human beings promote their intentions practically through a network of interlocutors. Indeed, practical reason enhances communicative action among human species and promotes their mutual understanding. This reconstructed communicative conception of reason, becomes universal because it envisages all different interlocutors:

${ }^{211}$ Habermas vision is that self-satisfaction inherent in European thought has caused structural conflicts and tensions in European culture. (I would suggest considering the revolt of marginalized skin colored groups some often occurred in Paris and Marcy as example of these tensions). See Jürgen Habermas, "Why Europe Needs a Constitution," New Left Review no. 11 (September-October 2001): 5-26. Also see Jürgen Habermas, Structural Transformation of the Public Sphere: An Inquiry into a Category of Bourgeo is Society, Thomas Burger trans., (Cambridge: MIT Press, 1989).

212 Jürgen Habermas, Theory and Practice (Boston: Eacon Publishers, 1973), pp. 41-81. 
Only in emancipated society, whose members' autonomy and responsibility had been realized, would communication have developed into the non-authoritarian and universally practiced dialogue from which both our model of reciprocally ego identity and our idea of true consensus are always implicitly derived.213

In order to investigate how Habermas justifies his account of communicative reason, we need to understand the meaning of his philosophical reflection. For Habermas, true philosophy is about a conception of reason that is embodied in cognition, speech, and communicative action. True philosophy is a totalizing reflective plan encountering the whole natural and social world. In its post-metaphysical currents, it converges toward a kind of rationality which carries with it emergence of a new constellation in the relationship of philosophy and sciences. ${ }^{214}$ True philosophical reflection therefore involves a communicative conception of reason that characterizes the universal features of communicative action as remaining open to empirical-reconstructive test and refutation. Communicative reason overcomes the one-sided focus on cognitiveinstrumental rationality. It takes its universal validity from the argumentative logos allowing different participants to reconcile their diverse views in social life. Due to mutually communicative character of this reconstructed conception of reason, different participants in communicative action coordinate intersubjectively with their objective world. ${ }^{215}$

The immediate consequence resulting from such a communicative conception of reason is an all-encompassing critical theory that encounters all distinct identities participating in communicative action to coordinate intersubjectively their objective world. Once there is a disagreement between the participants in a communicative action,

\footnotetext{
${ }^{213}$ Habermas, Knowledge and Human Interests, p. 314.

${ }^{214}$ Habermas, The Theory of Communicative Action, pp. 1-2.

215 Ibid., p. 10.
} 
they enter into a process of moral argumentation in order to achieve a consensus. Participants entering into communication allow their wants to be criticized by other participants, thus the consensus achieved is universal. "I must submit my maxim to all others for the purpose of discursively testing its claim to universality".216

Put succinctly, communicative action comes to be like a circular process in which the participants are both producers of situations that they have provided, and the product of the transitions surrounding them. Participants then become a social group, whose communicative action is grounded upon the solidarity to which they belong. The communicative reason guides those actions and the processes of socialization in which participants are reared. ${ }^{217}$ Through communicative action participants become capable of establishing a notion of truth characterized by autonomy of rational consensus. This truth is the consensual plan of action coordinated by participants through their communicative action. $^{218}$ Informed by Habermas, Linklater promotes the idea that the "telos" of communicative action is to achieve a substantive agreement about universal principles. That is legitimacy of actions gained through the consent of all those affected by them. ${ }^{219}$ The theory of communicative action therefore replaces the Kantian abstract principle of universal law and becomes the key to the project of emancipation. It is emancipatory because as opposed to pre-existing universal principle upon which participants are called into dialogue, participants self-reflectively determine the universal principle. ${ }^{220}$

${ }^{216}$ Jürgen Habermas, Moral Consciousness and Communication Action (Cambridge: The MIT Press, 1990), p. 67.

${ }^{217}$ Habermas, The Theory of Communicative Action, p. 135.

${ }^{218}$ Habermas, Moral Consciousness and Communication Action, p. 58.

${ }^{219}$ Andrew Linklater, "The Problem of Community in International Relations," Alternatives 15 (1999): 142.

${ }^{220}$ Linklater, "The Problem of Community in International Relations," p. 107. 
In sum, critical theory not only seeks to demonstrate the failure of the scientific approach to social relations, but also believes in the emancipatory purpose of social theory. Liberating man from his self-imposed material-based social relations, and guiding him toward the question of how to live, is the ultimate goal of such an emancipatory purpose of critical theory. Critical theory must therefore reinforce the emancipatory force of rational autonomy as opposition to a positivist notion of knowledge in order to make man capable of stepping beyond the status quo. ${ }^{221}$ To achieve such a purpose, critical theory comes also to be an account of ethical life in which the particular participants in communicative action are not excluded, assimilated or being subjected to nationalist (nation-state based) or fundamentalist patterns of identity presentation. Rather, they are depicted as participants in a universal open dialogue in light of the self-understanding and self-determination of their culturally and ethically differentiated values. This account of identity, Habermas argues, due to its emancipatory purpose is recognized by all concerned participants in communication. ${ }^{222}$

Critical theory has become a powerful source of inspiration in addressing the issue of recognition in International Relations. Indeed, the emancipatory purpose of critical theory, deriving from the contextualized universal principle of communicative rationality, is arguably the most appropriate framework in the realm of international relations to analyze and understand the distinctive identities and their struggle for recognition. Furthermore, its emancipatory purpose directs the theory beyond mere understanding and analysis of the failure of mainstream international relations theory. It becomes a subversive theory and a project of change.

\footnotetext{
221 Jürgen Habermas, Philosophical Discourses of Modernity (Cambridge: Cambridge University Press, 1987).

${ }^{222}$ Habermas, Moral Consciousness and Communication Action, p. 63.
} 
Derived from a range of European thoughts and the projects of emancipation, Critical International Relations Theory has mainly contributed to the development of the normative overlaps between political theory and International Relations. ${ }^{223}$ This overlap, as Steve Smith puts it, is characterized as a kind of escape from mainstream theory. ${ }^{224}$ Critical International Relations Theory is not a single discourse criticizing mainstream theory. Rather, it is a body of thought spanning from Gramscian theorists such as Robert $\operatorname{Cox}^{225}$ to the Frankfort School approaches of Andrew Linklater, Mark Hoffman, ${ }^{226}$ and Mark Neufeld. This categorization can easily escape from precision in intellectual distinction and remains open to re-classification. Critical theory, indeed, is a matter of constellation of distinct approaches each of which with different intellectual domain, but all tend to illuminate the importance of emancipation. ${ }^{227}$

\footnotetext{
223 Richard Wyn Jones in Critical Theory and World Politics identifies two main sets of influences acting upon critical international relations theory: First is the Frankfurt School which influences normative and political theory, and the second is the Gramscian School influences scholars concerned with political economy. See: Richard Wyn Jones ed., Critical Theory and World Politics (Boulder: Lynne Rienner Publishers, 2001), p. 5. ${ }^{224}$ Steve Smith, "The Forty Years Detour," Millennium Journal of International Studies 21, no. 3 (Winter 1992): 489-506. Also look at Brown, International Relations Theory: New Normative Approaches; Torbjorn $\mathrm{L}$. Knutsen, $A$ History of International Relations Theory (New York and Manchester: Manchester University Press, 1992); David Boucher, Political Theories of International Relations (Oxford: Oxford university Press, 1998); and Nicholas Rengger, "Political Theory and International Relations: Promised Land or Exit from Eden?" International Affairs 76, no. 4 (2000): 755-70.

225 Robert Cox has attempted to illustrate the influence of Gramsci in the development of post-positivist international relations. Robert Cox, "Social Forces, States and World Order: Beyond International Relations," Millennium: Journal of International Studies 10, no. 2 (June 1981):126-55; Robert Cox, "Gramsci, Hegemony, and International Relations: An Essay in Method," Millennium: Journal of International Studies 12, no. 2 (June 1983):162-75; Robert Cox, Production, Power, and World Order: Social Forces in Making of History (New York: Columbia University Press, 1987); and Robert Cox, "Social Forces, States, and World Orders," in Neo-Realism and its Critics, Robert Keohane ed. (New York: Columbia University Press, 1986), pp. 205-54.

226 Mark Hoffman, "Critical Theory and the Inter-Paradigm Debate," Millennium: Journal of International Studies 16, no. 2 (June 1987): 231-49.

${ }^{227}$ Jones, Critical Theory and World Politics, pp. 4-9. Also see Keyman, Globalization, State and identity/Difference: Toward a Critical Social Theory of International Relations (Atlantic Highlands: Humanities Press, 1997).
} 
Among critical theorists, Andrew Linklater has developed one of the most influential and the most widely-cited strands of Critical International Relations Theory. ${ }^{228}$ More particularly he has become well known because of portraying a theoretically reflexive vision of the world as well as a politically more inclusive account of critical theory. ${ }^{229}$ Following Habermas' challenge of positivism and its discourse of instrumental rationality, Linklater rigorously calls the positivist assumption of neo-realism into question and suggests a "critical turn" as the characterization of the current situation in scholarship. ${ }^{230} \mathrm{His}$ emphasis on the moral and political aspects of theorizing, because of a lack of any real response from the side of neo-realism, has established him as one of the most influential proponents of critical International Relations Theory.

Linklater develops his normative critical theory based on an assessment of the centrality of inclusion-exclusion discourse as the most important aspect of social bonds in political community. His aim is to reflect upon the disfranchised conception of citizenry and open a new horizon of "transcultural values and respect for cultural differences in modern international relations". ${ }^{231}$ This is a recurrent moral interest to see whether there is a ground for inclusion of citizens and exclusion of non-citizens others from the moral community and whether a universally accepted discourse can be developed that reconciles culturally divergent identities with their own conception of themselves within the polity. These questions - identity and the boundaries of political community - are the

\footnotetext{
${ }^{228}$ Nicholas J. Rengger, "Transformations of Political Community," Book Review, International Affairs 74, no. 3 (July 1998): 631-32. Also see Keyman, op. cit, p. 98.

${ }^{229}$ Grovogui, Beyond Eurocentrism and Anarchy, Memories of International Order and Institutions, p. 48.

${ }^{230}$ Andrew Linklater, Beyond Realism and Marxism (London: Macmillan, 1990). Eviden tly, Linklater

dismisses Gramscian and post-structuralism as critical schools, and rather takes Habermas as the source of inspiration for his theory.

${ }^{231}$ Andrew Linklater, "The Question of Next Stage in International Relations Theory: A Critical-Theoretical Point of View," Millennium Journal of International Studies 21, no. 1 (March 1992): 84. Also see Andrew Linklater, "Men and Citizens in International Relations," Review of International Studies 7 (1991): 23-37.
} 
central themes in developing an unapologetically universalistic-normative discourse that extends beyond the system of sovereign state and defend the "widening of the moral boundaries of political community".232 For Linklater, the positivistic tendency of neorealism, by its nature, prevents such a widening of boundaries, because neo-realism is concerned only with the reproduction of the nation-state based international relations, hence it disregards any radical transformation of system. Therefore, there is a need to remove the constraints assigned by neo-realism to the international system in order to promote a conception of global society in which freely chosen moral principles are the determinants of international relations. Those principles allow the autonomy of all human beings to be the foundation of international relations, and not the volition of "the most powerful or potentially disruptive sovereign states" concerned with the maintenance of order and stability between themselves. ${ }^{233}$

Mainstream International Relations Theory has neglected to analyze the principle of autonomy of all human beings, because it has focused on the society of states. In this society, the existing boundaries prevent the ideal of a universal discourse respecting cultural autonomy. Evidently, the society of states aims to maintain the international order without risking that individual citizens or culturally distinct groups "challenge the state's legitimacy by proclaiming their allegiance to a higher cosmopolitan ethics".234 However, international order is being challenged by the changes caused by the process of globalization. By decentralization of international order, globalization nourishes the politics of identity and community and, hence requires us to think about the issue of

\footnotetext{
${ }^{232}$ Andrew Linklater, Transformation of Political Community (Cambridge: Polity Press, 1998), p. 2.

${ }^{233}$ Linklater, Transformation of Political Community, p. 22.

${ }^{234}$ Andrew Linklater, “The Problem of Community in International Relations," Alternatives 25 (1990): 136.
} 
cultural distinctiveness as the key indicator in the post-Westphalian re-theorization of international relations. Linklater argues that the fundamental changes created in the international order encourage us to think about

... the emergence of new forms of political community in which the potential for higher levels of universality and difference is realised and, in so doing, and transcends the limitations of the Westphalian era. ${ }^{235}$

Formed by inclusive inter-dialogue among culturally distinctive identities, new political community would render the totalizing international order obsolete and empowers marginalized voices of dissent to construct a deeper political discourse committed to the wealth of human difference. Multicultural dialogue then comes to be the appropriate means of achieving recognition of culturally located different identities, who "are equally free to express their moral claims, able to explore the prospects for solving their moral differences and capable of reaching an appropriate compromise in the absence of consensus". ${ }^{236}$ Therefore, dialogue becomes the foundation of the new 'cosmopolitan community' of mankind, as opposed to both liberal accounts of cosmopolitanism and communitarian accounts of distinctiveness. ${ }^{237}$

The general principle to be upheld in the community of mankind proclaims the pursuit of universal freedom and equality as a project to maximize inclusion of different others, whose responsibility is "to engage others, irrespective of their racial, national and other characteristics, in an open dialogue about matters which impinge on their

\footnotetext{
${ }^{235}$ Linklater, Transformation of Political Community, p. 45.

236 Ibid., p. 92.

${ }^{237}$ The conception of 'cosmopolitan community' theoretically provides openness to culturally different identities. In discussing the notion of citizenship, Linklater enhances such openness and argues that citizenship includes different identities as sub-state communities within the whole 'cosmopolitan community'. See Andrew Linklater, Men and Citizens in Theory of International Relations (London: Macmillan, 1990); and Andrew Linklater, Boundaries in Question: New Directions in International Relations (London: Pinter, 1995).
} 
welfare". ${ }^{238}$ The universality of open dialogue discourse does not originate from its Western origin of natural law, nor is it assumed in accordance with teleological accounts such as that of history of philosophy associated with the Enlightenment, Linklater argues. It rather derives from a balance upheld between universalism and particularism with the aim of pursuing freedom and equality for all participants in an open dialogue. Inspired by Habermas, the idea of dialogic community includes culturally different but morally equal individuals affected by decision making, who come together to remove inequality and unjust practices in accordance with the consented norms. The principle of consent is the best means for both achieving the aspiration to universalism..$^{239}$

Cosmopolitan community informed by an ethical imperative of dialogue shows the perspective for a thin universality according to which every human being has an equal right to participate in the open dialogue. Indeed, the dialogic community includes culturally different but morally equal individuals, and never "claim the right to choose systems of inclusion and exclusion without involving those who may be adversely affected in open dialogue". ${ }^{240}$ In a dialogical community, participants open the gate of dialogue to members of all groups to learn the practice of inclusiveness as the foundation of the community of mankind. In a dialogical community, participants in the universal "kingdom of ends" learn how to destroy the systems of exclusion and how to practice a universal communication community in which all are free from domination. In this pattern of thin cosmopolitan community, the principle of universality is understood by

\footnotetext{
${ }^{238}$ Linklater, Transformation of Political Community, p. 101.

${ }^{239}$ Richard Shapcott, "Cosmopolitan Conversations: Justice, Dialogue and the Cosmopolitan Project," Global Society 16, no. 3 (2002): 226. Also see Richard Shopcott, "Critical Theory," in The Oxford Handbook of International Relations, Christian Reus-Smit, Duncan Snidal ed. (Oxford: Oxford University Press, 2008), pp. 327-345.

${ }^{240}$ Linklater, Transformation of Political Community, p. 103.
} 
virtue of answerability to all others. Put succinctly, the universality of moral law Moralitat - derives from the consent of all participants in open dialogue, and gives strength to the plurality and solidarity in international society. ${ }^{241}$

A concern with the recognition of culturally different identities in a dialogic cosmopolitan community highlights the importance of critical theory in the redefinition of the post-Westphalian international order. Attempting to address the instability driven from the crisis of identity and meaning in the Post Cold-War era, critical theory problematizes the very foundation of political thought as well as the fundamentals of international relations. In other words, inspired by Habermas' post-national account of identity, Critical International Relations Theory launches a project of the PostWestphalian political community, which moves beyond the Westphalian order and promotes a more inclusive perspective as opposed to the exclusiveness of national-based order. $^{242}$ It aims to broaden the moral boundaries of political community beyond the narrowness of the sovereign state system, hence promotes the engagement of different others in dialogue. As a result, it follows that dialogue among participants is the substantive means of recognition of others. Indeed, the "other" is recognized as different and yet equal.

However, the conception of dialogical cosmopolitan community encountering cultural differences is not without its problems. In particular, the intellectual thrust of such a conception can be challenged by theories of recognition. Since critical theory gains its intellectual strength from a reconstructed Kantian tradition, it narrows the focus of philosophical investigation and cannot take the insight of different others into account in

${ }^{241}$ Linklater, Transformation of Political Community, p. 178.

242 Ibid., p. 165. 
the portrayed cosmopolitan community. The current life-world is moving forward toward a progressive advance in a human's capacity to attain a moral insight with a more universalistic perspective. ${ }^{243}$ Within this perspective, the existence of cultural and identity differences is conceived of as being excluded from the advancing orientation of the modern life, hence, it will be cured when different others are included in a more encompassing universalistic perspective of the life-world. Inclusion is, indeed, achieved when different others are somehow abstracted from their own distinctiveness. Accordingly, the importance of difference as a vital need for cultural and identity formation does not resonate deeply. For example, although post-colonialist movements appeal for a more inclusive universal order and incorporation into the advancing direction of modern life, such appeal does not end their exclusion. Moreover, it is not clear how dialogical cosmopolitan community can cure the problem of exclusion in the world of domination without addressing the issue of difference as an indication of identity and culture. It seems that Linklater's model does not much differ from a thin pluralist liberalism which disregards the substantive visions of the good life of different others. This critique is soundly advanced by theorists of recognition - as will be discussed in the next chapter - arguing that critical theory's insight of difference threatens alternative modes of the life-world. In other words, critical theory presumes and privileges a certain way of conceiving the world that is, itself, a kind of exclusion and renunciation of the other style of life. To put this differently, the universalistic thrust of critical theory seems to be itself one particular vision among many and cannot satisfy the demand of difference.

\footnotetext{
${ }^{243}$ Ibid., pp. 28-33. And, Linklater, "The Problem of Community in International Relations," pp. 143-146.
} 
We would expect, then, that this model becomes a hegemonic framework within which all other forms of cultural life are judged. ${ }^{244}$

In addition, the sense of suffering from the unjust nature of world order, which impacts the grammar of a number of contemporary political conflicts and social movements, is not addressed by the dialogical cosmopolitan model of critical theory. Nor does this model acknowledge the fact that a re-articulation of the post-national life-world requires a redistribution of social goods along with the recognition of difference. In general, in the contemporary world we are confronted with a new constellation, where politics of recognition and politics of redistribution should play equal role in the promotion of social justice. What is required, indeed, is a conception of social justice that is grounded on the combined basis of redistribution and recognition. In this new constellation, the two kinds of justice are disassociated from one another. ${ }^{245}$ It is, therefore, imperative to address the experience and discernment of exclusion together with a struggle for redistribution of resources and social goods as well as equal participation and contribution. No single approach alone can sufficiently address the issue of exclusion and the otherness. ${ }^{246}$

In light of these considerations, I would suggest Taylor's account of recognition to be counted as an appropriate approach in addressing the struggle for recognition both in domestic and international spheres. Recognition, in this way, provides a solid ground for

\footnotetext{
${ }^{244}$ Naeem Inayatullah and David L. Blaney, International Relations and the Problem of Difference (New York: Routledge, 2004), pp. 122-123.

${ }^{245}$ See: Nancy Fraser, "Social Justice in an Age of Identity Politics: Redistribution, Recognition, and Participation," in Redistribution or Recognition?: A Political-Philosophical Exchange, Axel Honneth and Nancy Fraser ed. (London: Verso, 2003 ), pp. 1-48, and Nancy Fraser, Scales of Justice: Reimagining Political Space in A Globalizing World (Malden: Polity Press, 2008), pp. 12-29. Richard Wyn Jones raises the same criticism arguing that neither paradigm i.e. recognition or redistribution alone is adequate for the task of understanding of the other. See: Jones, op. cit., p. 17.

${ }^{246}$ Fraser, "Recognition without Ethics," p. 22.
} 
theorizing a recognition-based formulation of justice. These two characteristics, i.e. recognition as the constitutive element in a definition of identity and a foundation for justice, are the crucial motives moving us from a mere analysis of recognition as a philosophical argument toward theorizing ethics of recognition in international relations. This formulation becomes itself a pathway to draw on a new perspective of justice, as it will be articulated in the following chapter.

In conclusion, alternative theories of International Relations do not effectively and sufficiently address the existence of difference as the constituent factor in the definition of identity and the definition of justice. These theories simply acknowledge the existence of "difference" rather than recognizing the difference and allow it to have political representation (Emphasis added). The alternative theories only acknowledge the differences that exist among given identities. But the philosophy of recognition extends beyond the mere acknowledgment of the difference and draws on the recognition of difference as a priori factor in the formation and articulation of identity as well as a pathway to a new notion of justice; especially a recognition-based justice. For this reason, recognition more appropriately philosophizes and addresses the issue of social justice in the glocalizing world of fundamental transformations and identity politics.

Having challenged the distributive-based understanding of social justice and according greater importance to the demands of different peoples, the recognition and recognition-based approach to justice is gaining significant momentum. In other words, coming from the phenomenological tradition and as the thrust of Sittlichkeit - "ethical life" - recognition is becoming the driving force behind the contemporary theory of social justice. If, in ethical life, equal participation is required, then the objective condition of 
equality such as a redistribution of resources or the mere acknowledgment of difference is not sufficient for social justice. What is required instead is providing the intersubjective condition of participation. That is to say, participatory parity is attained through mutual recognition of the equal values of all participants and ensures that an opportunity is provided for all to achieve equal social status. In this perspective, recognition of difference comes to be an alternative approach to social justice and more reliable social bonds. This approach, in a considerable way, opens up a new horizon to reflect on the alternative visions of social justice in our life-world. In the following chapter, the phenomenological roots of the philosophy of recognition from the view point of Charles Taylor will be analyzed. My aim is to set a particular theoretical scene for the advancement of an ethical theory of recognition in International Relations. 


\section{Chapter 3}

\section{Beyond Mere Respect: Towards the Politics of Recognition}

The thesis is that our identity is partly shaped by recognition or its absence, often by the misrecognition of others, and so a person or group of people can suffer real damage, real distortion, if the people or society around them mirror back a confining or demeaning or contemptible picture of themselves. Nonrecognition or misrecognition can inflict harm and can be a form of oppression, imprisoning someone in a false, distorted, and reduced mode of being

Charles Taylor, "The Politics of Recognition", p. 25.

The theory of recognition signals a shift away from mere respect - or in language of Taylor "recognition as courtesy" - to public and political recognition of identity and cultural difference. Within this perspective, misrecognition or non-recognition is seen as inflicting grave harm. That is why recognition is to be considered as a "vital need" and not just a courtesy owed to people. ${ }^{247}$ This shift has implications for politics and political landscapes, especially for the study of international relations. Such implications have partly been addressed by liberals, such as John Rawls in his The Law of Peoples, and in part by the critics of liberals, and more importantly by theorists of recognition. They have given rise to a reinvigorated and heated dialogue around the development of the literature and theorizing of social justice. The critics are especially interested in challenging the singular and distribution-based understanding of justice being, promoted in the liberal perspective. Attention is instead drawn to an understanding of a recognition-based and participatory approach to social justice that addresses effectively identity and cultural differences. In this approach, we can see that recognition is

${ }^{247}$ Taylor, "The Politics of Recognition," p. 226. 
thoroughly tied not only to distribution, but more so to the cultural and institutional components of justice.

Recognition here refers to more than mere respect or toleration of existing identities. It entails rather reciprocal recognition and the social arrangements through which all members of society are allowed to interact with one another based on their equal worth. "What is picked out as of worth is a universal human potential, a capacity that all humans share".248 That is to acknowledge and ensure that this potentiality is respected equally in everyone regardless of racial or cultural differences. In other words, just as all must have equal civil rights, so all should enjoy the presumption that their traditional culture has equal value. Accordingly, recognition not only acknowledges the equality of their differences, but also esteems the equal worth of those who are culturally different. To put this differently, recognition not only requires all of us to recognize the equal value of different cultures and let them survive, but also to acknowledge their equal worth. In light of such acknowledgment, recognition and the recognition-based approach to justice has become a pressing demand in the contemporary life-world. From this perspective, failure to recognize different "others" not only inflicts harm, but more importantly casts a person or group of persons in a "false, distorted, and reduced mode of life". ${ }^{249}$ Those peoples or the group of persons who are imprisoned in a distorted way of life, indeed, are excluded from socio-political discourse. It is not surprising though that the struggle for recognition has become the driving force behind identity movements both in domestic policies and at the international scale. The difference between these two sorts

\footnotetext{
${ }^{248}$ Taylor, "The Politics of Recognition," p 235

${ }^{249}$ Charles Taylor, "The Politics of Recognition of Difference," in Philosophical Arguments (Cambridge: Harvard University Press, 1995), p. 225.
} 
of movements is that the first one comes to be a strong cause of social cleavage and political fragmentation, the latter is becoming a decisive resurgence against the preestablished international order.

The dialogue over this sort of resurgence and the political recognition of difference adds further value to the importance of theories of recognition. In this sense, dialogue is referred to as a means to recognize those who struggle for mutual recognition of their differences. Indeed, through dialogue and mutual recognition, one's identity is intersubjectively formed. The struggle for recognition, therefore, is more than mere intersubjectivity advanced by strands of critical theory. It is a struggle for recognition of individuals, groups, and nations in the real world; that is, a timely and urgent struggle to know who they - as distinct cultural identities - are. Assuming oneself in dialogue with others, one evaluates and interprets the "others" actions, and adjusts valuable things in fulfilling one's life. These kinds of evaluations, which are the "affective modes of awareness of situation"250 of oneself, are related to the social status of the "others". They also expose one's genuine moral experience as gained through dialogue and struggle for recognition. This pattern of evaluation, dialogue, mutual response, and reciprocal recognition can be extended to a group of individuals - an ethnic, racial, gender, and/or national identities. The idea promoted hence is to challenge a vision of persons, either individually or bounded in socio-cultural groups, as mere atoms which have been accumulated in impartial frameworks and are disinterested in distinctive evaluation of the values of others.

${ }^{250}$ Charles Taylor, "Human Agency and Language" in Philosophical Papers I (Cambridge: Cambridge University Press, 1985), p. 48. 
The point of departure of theorists of recognition from theorists of difference lies exactly in the very evaluation of one another's worth. To be more specific, in this way, struggle for recognition of difference implies indispensable political weights, also fundamental moral importance for both interpersonal relation and the international relations of groups of individuals and nations. Essentially, recognition is a vital human need, ${ }^{251}$ and its absence, then, causes inequality, and ultimately an unjust world order. For this reason, as already mentioned, recognition of difference is to be counted as the central theme in debates about justice, and more particularly as an urgent argument to be promoted in international relations discourse.

This chapter begins with an elucidation of the philosophical traditions from which the contemporary conception of recognition takes its roots. Then the moral significance of recognition for conflicting identities and the question of why theories of recognition have been developed differently will be discussed. Such a discussion especially allows us to compare the degree of efficiency of the theories of recognition in addressing the issue of justice. By analyzing Charles Taylor's account of recognition, this chapter also depicts a vision of recognition that is more efficient in addressing the issue of differences. The end purpose of the chapter is to provide a solid argument for promotion of the recognition of the difference in the study of international relations

\section{Theory of Recognition}

The idea that human beings - either individually or by group - by virtue of their identity and cultural belonging are different is not a new idea in human reflection. But, the conviction that people strive for their own authentic voice and representation against the

${ }^{251}$ Taylor, "The Politics of Recognition," p. 226. 
patterns of exclusion, annihilation, and oppression, and that such striving must be recognized has recently become the focus of political thinkers' inquiry. The struggle for recognition in this sense has also become a matter of justice. In light of these observations, a kind of decoupling from the idea of redistribution which is the hallmark of liberal thought and instead moving toward the demand for recognition on behalf of excluded groups has become the focus of attention of political thinkers. It would be convincing to argue that such a shift toward recognition is indeed a response to contemporary transformations in the political landscape that I described in chapter one.

However, to have an accurate analysis and understanding of the idea of recognition one needs to look at the roots of this conception at the dawn of modernity. Indeed, it was from early modern times that some thinkers criticized the Enlightenment idea that all human beings, by virtue of their equal rational autonomy and dignity, share the same identity and must be treated accordingly. For the thinkers of Romanticism, specific cultural and linguistic background and "horizons of meaning" shaped identity. Individual persons are different because they are identified within their background. That is to say, they are self-interpretive beings who express themselves based on their different background. However, the self-interpretation takes place in a network of social relations, where different selves dialogically and mutually recognize one another's authentic self-expression. We gain, indeed, the sense of being human as long as we interpret our selfhood in dialogical relations with other selves, for whom the same as us and in accordance with their own significant background, express themselves differently. This difference must be recognized as a true source of social bounds. In what follows, I will briefly look at this expressivist account of the constructed self, while attempting to 
extend the line of argument to the sense of collective being in a cultural sense. For this purpose, I offer a short analysis of the conception of recognition as a philosophical sketch. In order to do so, I begin with a brief analysis of Herder's expressivist account of the self and end with Hegel's mutual recognition. This journey is imperative for understanding the importance of the conception of recognition and the way through which it is applied to the field of International Relations.

The importance and the relevance of Herder to the idea of recognition lie in a distinction between autonomous and expressivist accounts of the selfhood. Following Kant, the autonomous self refers to a conception of rational and sovereign being who is subjected to his created laws and policies. In other words, the autonomous individuals or atomised selves are both the source and the subject of law. This account of the self disregards the importance of the communal life for meaningful choice and true exercise of autonomy. On the contrary, expressivism insists to view that humans are expressive selfdefining subjects with inner depths, nourished by nature and explored its potentials through membership in the community. Hence, they need communal life and recognition from other subjects. To put it differently, expressivism means that human beings possess an inner power that seeks to express and maintain their own identity against those the surrounding world might impose. ${ }^{252}$ Expressivism is concerned with an understanding of how individuals are bounded within time and places and, hence admits the argument that selves are capable of constructing their own world and the good in accordance with their own cultural background. This argument is the base of theory of recognition: "We

\footnotetext{
${ }^{252}$ Charles Taylor, Hegel (Cambridge: Cambridge University Press, 1975), p. 15. Also Taylor, "The Expressivist Turn," in The Sources of the Self, op. cit., pp. 368-386; and Taylor, "The Importance of Herder," in Philosophical Arguments, op. cit., pp. 79-99.
} 
everywhere find mankind protecting and exercising the right of forming themselves to a kind of humanity, as soon as they have discerned it". 253

A deeper look at the expressivist account of the self reveals also the fact that the explanatory and cognitive resources available for us to deal with the phenomenal world are diverse. Because of such diversity we have different understanding of our world. For this reason, the culture of different groups and nations is true to themselves. Since men are different and narrate their own history differently, nobody stands in a higher status other than fellow humans. Indeed, nothing is more deceptive than the application of one form of culture to all periods of time and all different nations. If we are free to design our own life plan, our fellow humans ought to have the same freedom equally. That is to confirm many different lines of cultural and identity development. Each culture has a singular and wonderful identity embodied a distinct vision of human life: "Every nation has its own centre of gravity, and therefore the means for its happiness within itself".254 It is only in this sense that equality would genuinely be meaningful. We must recognize the equality of our difference.

Being aware of the diversity of historical periods, Herder recognizes the unique characteristics of different nations, groups, and cultures, asserting that even different strata of classes within a society have the capacity, on the basis of the strata's particular activities, to form cultures and, as a consequence, stand away from any universal account of identity formation. In this respect, and being the expressivist critique of individualism

\footnotetext{
253 Taylor, "The Politics of Recognition," pp. 272-273.

254 Johann Gottfried Herder, Another Philosophy of History and Selected Political Writings, Ioannis D. Evrigenis, Daniel Pellerintrans. (Cambridge: Cambridge University Press, 1969), p. xxviii.
} 
and instrumentalism associated with Enlightenment humanism, ${ }^{255}$ Herder argues that we understand our world through articulating what we find within us. This stress on something within us forms our history differently. So, "that in all his earthly institutions man can conceive no other end, than what lies in himself". ${ }^{256}$ Indeed, we articulate our selfhood in terms of our different understanding and discovering of the world. That is to assert that our self-articulation is expressed in different manners, and, as a consequence provides us with a fuller individuation. Accordingly, it must be confirmed that "each person is to be measured by a different yardstick, one which is properly his or her own". 257 Based on this depiction of the self, one is required to seek understanding of how people are bounded differently within cultural traditions, times, and spaces. In light of this expressivist analysis, individuation is defined first in terms of the cultural life, and second by virtue of the diversity of cultural traditions. To specify further this assertion, since man's identity is affected by the cultural context that is valuable to him, he can hardly be considered similar to other cultural groups except when they reach a common ground through dialogue and mutual recognition. Common ground does not preclude the values of importance to people of distinct cultural backgrounds.

Being sympathetic with cultural particularism, Herder traces the roots of the sense of selfhood in the cultural development and advancement of people. This search for the sources of the self is seen as a universal principle for understanding of cultural differences around the globe. Herder calls this principle the "grand law of nature" and to support his

\footnotetext{
${ }^{255}$ The 'expressivist turn' was coined by Taylor in order to highlight the importance of the inner depths in development of the selthood. See: Charles Taylor, Hegel (Cambridge: Cambridge University Press, 1975), chapter 1. Also see Charles Taylor, Sources of the Self: The Making of the Modern Identity (Cambridge: Cambridge University Press, 1989), pp. 368-390.

${ }^{256}$ Herder, Outlines of A Philosophy of the History of Man, p. 272.

${ }^{257}$ Taylor, Sources of the Self: The Making of the Modern Identity, p. 375.
} 
vision argues that "let man be man; let him mould his condition according to what he himself shall view as best". 258 His argument for such an account of selfhood which gives way to diversity and multiculturalism is simply that since culture changes from one group to another, one must recognize the diversity of cultural values from society to society: "The whole cause of a man's life is change: the different periods of his life are the tale of transformation". 259 This idea of change and diversity discredits the Eurocentric dogma claiming that all people in the world in order to be happy must live similar to Europeans. Herder's account of the authentic path to the construction of identity decisively challenges the acceptance of a single pattern of life. He argues that a human:

[I]s the child of accident, who has placed him on this spot, or on that, and determined her capacity of enjoyment, and the kind and measure of his joy and sorrows, according to the country, time, organization, and circumstances, in which he lives. It would be the most stupid vanity to ignore that all habitants of the world must be European, to live happily. ${ }^{260}$

Admittedly, if societies are developed by cultivating their own distinct background, by their own diverse elements of time, organization, and circumstances, it wouldn't be plausible to postulate a unique pattern for understanding their different cultural traditions and values. Culturally developed identities are a matter of sensitivity to their historical conditions and different eras in distinct places. The community into which one is born is a matter of chance. If an American was instead born into a non-American culture, he or she would develop non-American cultural standards; and simply because these standards differ, there is no reason to presume their inferiority. At this point of reasoning, Herder insists that the value of human life and its path to happiness, similar to identity, should be understood from "within the living elements of its circumstances," and

\footnotetext{
${ }^{258}$ Herder, Outlines of A Philosophy of the History of Man, p. 272.

259 Ibid., p. 294.

260 Ibid., p. 393.
} 
that "such irregularities and contradictions ... are perfectly human". 261 The happiness of a society is, at all times, historically dependent on its language and culture. Paths to a happy life differ according to each nation, hence, we should avoid imposing a universal model to all groups or nations. What we especially need to recognize is that one is defined and formed through the internal relations and cultural developments of one's culture toward the goal of one's community.

Each form of human perfection then, is, in a sense, national and time-bound and, considered most specifically, individual. Nothing develops, without being occasioned by time, climate, necessity, by world events or accidents of fate..$^{262}$

The question of distinctiveness between societies is not a complete denial of similarities between different peoples, but when the very community takes its point of departure from previous times, each becomes almost unique in itself. It follows that "each nation has its own centre of happiness within itself, just as every sphere has its own centre of gravity". ${ }^{263}$ Herder used the concept of cultural differences for the first time in a modern anthropological sense to indicate the particular way of life of a period or group in changeable historical circumstances. Art, industry, commerce, science, political institutions, and literature as well as ideas, beliefs, customs, and myths were all recognized by Herder as constituent parts of a community's culture:

The practical understanding of man was intended, to blossom and bear fruit in all its varieties; and hence such a diversified Earth was ordained for so diversified a species. ${ }^{264}$

However, since an identifiable and overarching culture forms and characterizes a particular community, at a given time in history, it is possible that certain cultural

\footnotetext{
${ }^{261}$ Herder, Another History of Philosophy, p. 191.

${ }^{262}$ Ibid., p. 191.

${ }^{263}$ Ibid., p. 186.

${ }^{264}$ Herder, Outlines of a Philosophy of the History of Man, p. 374.
} 
features and activities dominate others during this historical formation. Following Montesquieu's line of thinking, Herder thought that an interaction of various environmental forces, individual powers, particular activities, and attitudes are all involved in the formation of a community's culture. The spiritual culture of a community follows "the true history of mankind, without which all the outward occurrences of this world are but clouds"265. That is the reason why Herder contends that the rationalism of the so-called Enlightenment "has really only touched and affected a narrow strip of the globe". ${ }^{266}$ Its pervasiveness can scarcely be altered without changing everything at the same time.

Recognizing that each nation has its own moral perspective deriving from its cultural background provides an insightful horizon through which different moral values and social goods co-exist peacefully, though they might not be commensurate. Human values cannot fit neatly together because they are irreducibly multiple, and frequently incompatible with one another. Our world is constructed of moral conflicts and disagreements between nations with their own cultural specifications. In this sense, there is no possibility that all moral goods can be realized simultaneously or that there is only one rational way of ranking them. Goods and their meanings should be understood within the language of practice, which is embodied in the form of social life. ${ }^{267}$ Herder developed a line of thinking that was relatively novel and incompatible with the rationalism of the Enlightenment period.

\footnotetext{
${ }^{265}$ Herder, Outlines of a Philosophy of the History of Man, p. 414.

266 Ibid., p. 216.

${ }^{267}$ Charles Taylor, "The Importance of Herder," in Philosophical Arguments (Cambridge: Harvard University Press, 1977), p. 93.
} 
The mythology of every people is an expression of the particular mode, in which they viewed nature; particularly whether from their climate and genius they found good or evil to prevail, and how happy they endeavoured to account for the one by means of the other. ${ }^{268}$

In sum, Herder's theory of originality of cultural identity reflects the fact that there is a complicated interaction of various environmental forces, individual powers, particular activities, and attitudes that go hand in hand in the course of history to form the distinct spirit or culture of a nation. From this line of thought, it follows that no society can be unified without dissent, because by its nature, society is composed of a diverse range of opinions and interests of its people. Accordingly, no individual person or individual nation can be imagined in isolation or in abstraction from their social contexts and their cultural traditions. Nor is it reasonable to believe that the particular moral good and value of a nation be repeated precisely the same in other cultural traditions. But, we can think that the similarities between activities and values of different cultures may overlap. These similarities enable us to recognize the particular values of nations. The ability to understand is the reason why it is possible to understand the aspirations, values, and ends of societies that are different from our own.

Although the crucial influence of Herder is evident in Taylor's theory of recognition, still such theory owes a great debt to Hegel, who developed the theory of "mutual recognition" in his famous dialectic of "master and slave" in the Phenomenology of Spirit. However, in spite of the importance of Hegelian account of recognition, and although being Hegelian in his philosophical insight, in "The Politics of Recognition", Taylor mostly draws on Herder rather than Hegel. This is simply because of, I believe, the central importance of Herder on the development of an expressivist account of the self

${ }^{268}$ Herder, Outlines of a Philosophy of the History of Man, p. 358. 
and multiculturalism. Upon a closer examination of Taylor's works, it is evident that, in his later works, Taylor has mostly benefited from Herder's philosophy. ${ }^{269}$ Still, we need to shed further light upon the idea of recognition in its Hegelian formulation in order to explore further the continuation of the idea of the historically situated and culturally mediated conception of the self and its cardinal importance in completion of the ethics of recognition, and notably the way through which the theory of recognition informs International Relations Theory.

Hegel presents his conception of recognition in two different works. In the Phenomenology of Spirit, he develops a subjective insight into the recognition of conformity with a self-subverting notion of consciousness, which is the most influential source of the theorizing of recognition. This self-subverting is demonstrated in the "master-slave dialectic". In the Philosophy of Right, an objective account of recognition with some changes to its context, offers an account of an affirmative mutual recognition. In this second account, recognition becomes a significant theme in Hegel's constructive philosophy of spirit; that is to say that recognition plays a crucial role in the formation of the ethical life. Indeed, in the ethical life possessing the rights presupposes recognition; recognizing of the right to have rights. This bifocal subjective/objective approach in the articulation of recognition is central to contemporary theories of recognition.

\footnotetext{
${ }^{269}$ Those works includes notably: Charles Taylor, "The Politics of Recognition," in Philosophical Arguments (Cambridge: Harvard University Press, 1995); Charles Taylor, The Dynamics of Democratic Exclusion," Journal of Democracy 9, no. 4 (1998): 143-56; Charles Taylor, living with Difference," in Debating Democracy's Discontent: Essays on American Politics, Law, and Public Philosophy, Anita L. Allen and Milton C. Regan ed. (Oxford: Oxford University Press, 1998), pp. 212-226; Charles Taylor, "Democracy, Inclusive and Exclusive," in Meaning and Modernity: Religion, Polity, and Self, Richard Madsen et al. ed. (Berkeley: University of California Press, 2002); Charles Taylor, "Understanding the Other: A Gadamerian View on Conceptual Schemes," in Gadamer's Century: Essays in Honor of Hans-Georg Gadamer, J. Malpas, U. Arnswald and Jens Kertshcer ed. (Cambridge: MIT Press, 2002).
} 
In Phenomenology, Hegel gives an account of struggle for recognition as a necessary intersubjective condition for self-consciousness. For the self to achieve selfconsciousness and fulfill the condition of his identity, he needs to see himself in the other as the other sees himself in the self. "Self-consciousness exists in and for itself when, and by the fact that, it so exists for another; that is, it exists only in being acknowledged". ${ }^{270}$ In other words, the existence of the self recognized by the other, and the other being recognized by the self - the mutual - results in a phase of spiritual unity out of which the movement for self consciousness progresses. Here that recognition comes to be the means of articulation of how two equal and independent persons mutually recognize one another. ${ }^{271}$ Recognition, then, by its nature requires that the self and the other acknowledge each other's equal rights. "They recognize themselves as mutually recognizing one another" (Emphasis in original text). ${ }^{272}$

As a phenomenon then theory of recognition begins with an argument about human inclination. ${ }^{273}$ Since an individual naturally seeks to satisfy inclinations, she or he becomes a self-centered being and "destroys the independent object and thereby gives itself the certainty of itself as a true certainty" (Emphasis in original text). ${ }^{274}$ This natural inclination should be dependent on a struggle for self-overcoming through which human beings find a socially mediated mentality. It is through this struggle that the recognition of others is attained: "Self-consciousness achieves its satisfaction only in another self-

\footnotetext{
${ }^{270}$ Wilhelm Friedrich Hegel, Phenomenology of Spirit, A. V. Miller trans. (Oxford: Clarendon Press, 1977), Para. 178.

271 lbid., Para. 182.

272 Ibid., Para. 184.

${ }^{273}$ Robert R. Williams, Hegel's Ethics of Recognition (Berkeley: University of California Press, 1997), p. 49.

${ }^{274}$ Hegel, Phenomenology of Spirit, Para. 174.
} 
consciousness" (emphasis in original text). ${ }^{275}$ Indeed, in order for this interpersonal relationship to be fulfilled, personal desire should be sublimated through a process of mutual recognition. This process provides the existential phenomenological genesis for the spirit:

What still lies ahead for consciousness is the experience of what Spirit is - this absolute substance which is the unity of the different independent selfconsciousness which, in their opposition, enjoys perfect freedom and independence: ' $I$ ' that is ' $W e$ ' and 'We' that is ' $I$ '.276

However, self-consciousness ought to find another living self-consciousness in order to reach truth. This "ought to" necessitates a shift from itself towards external selfconsciousness through a dialectical process between consciousness in itself and outside itself. The dialectical process is indeed the terrain based upon which recognition is accomplished. Hence, recognition which is the ontological focal point in Hegel's philosophy aims to contextualize the selfhood in light of the concrete social and historical context which expresses human inclinations. This contextualization is realized through a dialectical movement from consciousness towards self-consciousness.

Each is for the other the middle term, through which each mediates itself with itself and unites with itself; and each is for itself, and for the other, an immediate being on its own account, which at the same time is such only through this mediation. They recognize themselves as mutually recognizing one another (Emphasis in original text).277

Through transition from consciousness to self-consciousness, the individual being knows himself or herself as simply an "I", who is not for him or herself alone, rather for other selves; and this process of knowing take places through a dialectical process that is essential to life. Both moments of the simple, and, also, immediate self-consciousness

\footnotetext{
${ }^{275}$ Hegel, Phenomenology of Spirit, Para. 175.

276 Ibid.

277 Ibid., Para. 184.
} 
which is an "I" as a "We", are essential in living of an organic life, and are thus, universal. Such a process of recognizing "I" as "We", is universally true, hence, itself is a universal self-command ethics common to all human beings: "The category is therefore determined for consciousness as it is in its universal truth, as a being that is in and for itself" (Emphasis in original text). ${ }^{278}$ But, we should not be confused with such an ethical command to recognize our individual self as "we" by virtue of an outer command. The dialectical moment from consciousness to self-consciousness, which is culminated in the universal command of recognition of others, tests its universality with itself without referring to any external element: "For self-consciousness, its knowledge is the substance itself. This substance is for it just as immediate as it is absolutely mediated in an indivisible unity" (Emphasis in original text). ${ }^{279}$ The individual self, from such a perspective, is portrayed as the product of a collective self-determination with a highly ethical command.

In the essence we are considering here, individuality has the meaning of selfconsciousness in general, not of a particular, contingent consciousness. In this determination, therefore, the ethical substance is actual substance (Emphasis in original text). ${ }^{280}$

The universality of self-command ethics originates from the very individual selfconsciousness in the organic and living whole. Indeed, self-command ethics come from the experience that an individual learns from the transition from consciousness to selfconsciousness as being an essential way of life.

The self-command ethics needs more clarification because of its implications for the recognition of the difference. In order to coherently clarify the relationship of ethical

\footnotetext{
${ }^{278}$ Hegel, Phenomenology of Spirit. Para. 184.

${ }^{279}$ Ibid., Para. 597.

${ }^{280}$ Ibid., Para. 447.
} 
command in a process of self-consciousness, and to analyze the notion of recognition, we need to briefly turn our attention to Kantian ethics. According to Kant, deliberation takes place between universal duty and personal inclinations. For Kant the only thing that is unconditionally good is good will, and the goodness of the good will derives not from the purposed end, but rather from its willingness to perform an action from duty. ${ }^{281}$ This duty forms the foundation of the universal law of the categorical imperative. The problem with such a brilliant account of moral duty is that it is grounded upon personal reflections and is abstract in character, hence lacking an intersubjective reciprocal act of mutual recognition. ${ }^{282}$ For Hegel, there is no such a thing as a subject, because human beings, in order to be subjects, need an intersubjectively mediated and historical base, and should be understood in terms of their social context. This mediated notion of the subject is selfforming in the process of history. Being, however, is a universal virtue for its having mediation; when it expresses this in its immediacy it is a differentiated, determinate property. ${ }^{283}$ In this view, what comes to count as a subject is a contextualized life and realization of its purposes.

In Hegelian account, we cannot formulate the content of universal moral law without mutual recognition and reference to the history of what we, as well as others, have come to regard as universally moral. Any ethical action we undertake should be understood through the very individual inclination mediated dialectically by other selves: "Self-consciousness exists for self-consciousness. Only so it is in fact self-consciousness; for only in this way does the unity of itself in its otherness become explicit for it" (Emphasis

\footnotetext{
${ }^{281}$ Kant, Groundwork of the Metaphysics of Morals, Para. 393-98.

282 Williams, Hegel's Ethics of Recognition, p. 34.

${ }^{283}$ Hegel, Phenomenology of Spirit, Para. 113.
} 
in original text). ${ }^{284}$ Here Hegel reveals his attempt to reconcile universal duty and individual inclination through a dialectical process is revealed. But, we need to keep in mind that such a dialectical process is not like a series of mechanical synthetic unions. Rather, it is a continuum that transcends the limitations of ethical reflections between universal law and individual inclination and embraces a dialectically ever-changing process. Individuals are not self-subsistent identities, rather they are dialogical identities, which rest on a larger self-sustaining entity in which distinctions and differences are recognized through the process of self-consciousness.

By way of conclusion, the contemporary theories of recognition have their roots in a specific constellation of philosophical tradition concerned with the conception of the "self" through which inquiries have been launched into the question of differentiation in identity. It is not surprising to see, therefore, that the examination of the conception of recognition has indistinguishably interwoven with the philosophical accounts dealing with the formation of modern "self" and its sources. Spanning from Herder to Hegel, this tradition has offered an account of historically mediated and culturally situated conception of the self by making the notion of recognition as the central issue in philosophical examination. For the exponents of this tradition, recognition of different selves is an essential condition to identity. Parallel to this tradition is the one that often ignores the issue of difference and stresses the sameness of all human beings. Of course, both strands of philosophical thought similarly include the modern notion of the self, but they diverge in their view of how the modern self is understood. Resting on the idea of "sameness" with "oneself" the latter tradition - the Kantians - adopt the notion of the 
equality of the selves, while stressing the idea of "difference", the former - the Hegelians emphasize the equal recognition of difference. To put this succinctly, the controversy between the two traditions is about two sorts of recognition. While one strand espouses the idea of "sameness" upon which they recognize equality of the selves, the other believes in "difference" as an essential condition in identity formation, hence it also stresses the recognition of equality of different selves. The contemporary theories of recognition are to be examined via the comprehension of such a controversy upon the ideas of "sameness" and "difference", also an understanding of the inextricably interwoven relationship between the modern notion of the "self" and the conception of "recognition".

\section{The Politics of Recognition: Taylor's Account}

What does it mean to refer to a culturally distinct conception of identity as opposed to "identity" on its own? How can we distinguish between a historically mediated and culturally situated conception of identity from that of the abstract and unencumbered vision of the self? And, why should we distinguish between these conceptions of identity at all? These questions have been preoccupying Taylor's philosophical investigations, ranging from the theories of the modern self to the role of language in social life and from the hermeneutics of the lived experience to the conception of good life for more than three decades. Those major themes constitute the intellectual foundation of what comes to be the "politics of recognition of difference" in Taylor's philosophy. His politics of recognition is relevant to the debates on a wide range of contemporary social and identity movements such as feminism or subaltern groups struggling for recognition of their differences. But more importantly, and from the perspective of this thesis, the politics of 
recognition "is one of the driving forces behind nationalist movements in politics" on the one hand, and a vital need to surmount misrecognition or non-recognition inflicting harm, oppression, and "imprisoning someone in a false, distorted, and reduced mode of being" on the other hand ${ }^{285}$ Extended to international relations, as will be discussed in the following chapter, recognition in the latter sense is a condition of the state's actuality as well as the condition on which a just world order "ought to" be established.

However, the core debate in recognition is that the self should be recognized not only in terms of equality of his dignity and rights, but also in light of what brings him into relationships with other selves. Since people's dignity and rights bound up with autonomy, every individual person has the capacity to determine his own conception of human life. The latter idea manifests itself in the recent re-thinking on how social life and values are shaped in cultural contexts where identity groups are encouraged to struggle for recognition of their distinctive values and their own concepts of moral goods. In Taylor's account, this latter issue becomes a leading theme. He advances the thesis that the sources of the social goods for different societies and civilizations are so diverse that they cannot be captured by doctrines driven by single principles or values such as procedural liberalism. Rather, different autonomous selves flourish as long as they are fully embodied in a harmonized mode of living together with their own differences: "The crucial idea is that people can also bond not in spite of, but because of difference". ${ }^{286}$

Evidently, different and contrasting values and the various conceptions of the good life may come into conflict if they are not somehow harmonized or recognized by each

\footnotetext{
285 Taylor, "The Politics of Recognition," p. 225.

${ }^{286}$ Charles Taylor, "Living with Difference," in Debating Democracy's Discontent: Essays on American Politics, Law, and Public Philosophy, Anita L. Allen and Milton C. Regan ed. (Oxford: Oxford University Press, 1998), p. 214.
} 
other. Here is where the failure of the "difference-blind" insight finds further appeal. Returning to globalism/glocalism debate, it should be noted that since procedural liberalism claims to offer "a neutral ground on which peoples of all cultures can meet and co-exist", the requirements of the highly pluralizing [glocalizing] life-world is not met.287 Rather, difference is ignored, a viable sense of modern democracy is weakened, and more importantly some sort of conflicts among contrasting values is produced that undermines and endangers social solidarity in highly pluralized societies. It is worth repeating that difference-blind proceduralism ignores existing differences, and, hence, first of all refutes the recognition of difference as the constitutive factor in the formation of identity. Secondly, and by misrecognition or non-recognition, liberalism causes hurt and damages the sense of the selfhood and in this way undermines the achievement of a just world. Thirdly, by failing in the recognition of difference, liberalism destabilizes social solidarity. These three critical points i.e. recognition as the constitutive factor in the definition of identity, recognition as a genuine path to justice (a recognition-based conception of justice versus the universal principle of justice), and recognition as the inextricable source of solidarity, specify the principles of the politics of recognition. Such a thoughtprovoking approach to the recognition of difference makes Taylor a decidedly progressive thinker advancing a deep thesis addressing the requirements of our pluralizing world of cultures, values, and civilizations.

In light of the above observations, in what follows I will draw on the thesis that recognition in Taylor's account is, firstly, a determinant factor in the constitution of identity, secondly, the fundamental factor in the definition of justice, and, thirdly, the

\footnotetext{
${ }^{287}$ Taylor, "The Politics of Recognition," p. 249.
} 
principal element of solidarity. These three themes provides the intellectual bases for discussing the ethics of recognition in international relations.

The starting point in an analysis of Taylor's account of recognition is the examination of the expressivist conception of selfhood. The chief point of analysis seems to be a simple claim: we are autonomous selves exploring our sense of selfhood authentically from within. Through the inner depths we express ourselves and live with our own unique inner truth. Being true to ourselves means being true to our originality, which is something only we can articulate and discover. If the idea that we are truly autonomous beings is taken as valid, then the question to consider will be whether the quest for selfhood is abstracted from the social claims for recognition. Taylor's answer to this question is an unequivocal one. Although as modern selves we determine our authentic identity through the inner engagement, we discover ourselves and flourish through a constant subjective-transcending attempt to make sense of the things that matter to us in our lived experience. In fact, we define ourselves as selves by relying on both the inner source and the outer experience of interchange with others. Therefore, the things that matter to us as the object of our good life vary from one context to another. Taylor is straightforward in this claim: "My identity is defined by the commitments and identifications which provide the frame or the horizon within which I can try to determine from case to case what is good, or valuable, or what ought to be done, or what I endorse or oppose".288 This diversification of goods must not be restricted within the confines of any single, overarching principle such as the universal principle of humanity.

${ }^{288}$ Taylor, The Sources of the Self, p. 27. 
Nor should it be reduced to postmodern perspectivism and subjectivisms. ${ }^{289}$ Rather, the individual moral commitments, such as respect for principle of equality, must somehow be reconciled with diversification of the concepts of social goods and/or moral values.

The harmony between the two spheres would be clarified by referring to Taylor's interpretation of man as a self-interpreting animal. ${ }^{290}$ In this perspective, there seems nothing as what they are, independently of how they are being understood; they would all be meaningful for man by virtue of self-interpretation and self-understanding. In other words, self-interpretation should be seen as the base of all social goods and values. ${ }^{291}$ However, it would be hasty to leave this relativist-like and ambiguous assertion without clarification. The thesis advanced by Taylor is that self-understanding is taking place within a foregoing "horizon of significance" in which we understand ourselves. This is an inescapable framework through which we proceed to know who we are, hence forming our thinking, acting, and interpreting. It is beyond doubt that the framework of interpretation is informed by our language, culture and our practicing social goods. We live within this framework and give form to it. ${ }^{292}$ That is, our identity is bound up with the sense of significance we attach objects and situations we encounter in everyday life. Within this framework, we, self-interpreting animals, identify our goals, evaluate our

\footnotetext{
${ }^{289}$ Charles Taylor, "Foucault on Freedom and Truth," in Foucault: A Critical Reader, David Couzens Hoy ed. (Oxford: Basil Blackwell, 1986), p. 93. To read about the postmodern perspectivism see: Ilmour, John, C., "Perspectivism and Postmodern Criticism", Monist, 73, (April 1990): 233-246.

${ }^{290}$ Charles Taylor, "Self-Interpreting Animals" in Human Agency and Language: Philosophical Papers I (New York: Cambridge University Press, 1985), pp. 45-76.

${ }^{291}$ Charles Taylor, "Cognitive Psychology," in Philosophical Papers, Volume I (Cambridge: Cambridge University Press, 1985), p. 191.

${ }^{292}$ Charles Taylor, "Interpretation and the Sciences of Man," in Philosophy and Human Science II (Cambridge: Cambridge University Press, 1985], pp. 15-57.
} 
conceptions of the good life, and determine our patterns of a meaningful life. ${ }^{293}$ But, in spite of the fact that we discover our selfhood through our own original way of being human, we pursue it in light of social bonds, where others are doing the same interpretation of the good life. This horizon or framework binds us together even if we pursue our goals differently. ${ }^{294}$ This is the basis of the second constitutive feature of Taylor's interpretation of selfhood in accordance to which man is viewed as not only a self-interpreting animal, but inevitably as a strong evaluator of goods and values. ${ }^{295}$

It follows that we are autonomous agents, each with our own way toward the good life; a way which makes us distinctive selves. We do not follow the principle of sameness, disrespecting other's different ways to their meaningful life. We develop our original way of understanding ourselves and human life even in disagreement with the closest members of our family.296 The idea of sameness derives from the principle of humanity according to which all human beings are worthy of equal respect. The basis for such a respect lies in human's potential as a rational autonomous agent capable of directing his own life without interference of external forces. This account of the self amounts to the politics of universalism, favouring equal dignity of all individuals. The idea of authenticity promotes the distinctiveness of the individual - and group - identities, and, hence, aspires for a politics of difference. In this way, it comes to be an alternative to a universal principle of the equality of human dignity and calls for socio-political equal recognition of values that make human beings different. Taylor rightly argues that although there are

\footnotetext{
${ }^{293}$ Charles Taylor, "Self-Interpreting Animals," in Human Agency and Language: Philosophical Papers I (Cambridge: Cambridge University Press, 1985), pp. 45-76.

${ }^{294}$ Taylor, "Interpretation and the Sciences of Man," p. 40.

${ }^{295}$ See Rosa Hartmut, "Cultural Relativism and Social Criticism from a Taylorian Perspective," Constellations, 3 , no. 1 (1996): 39-60.

${ }^{296}$ Taylor, The Sources of the Self, p. 35-36.
} 
goods that are binding, within the strictness of these grounds, we, as moral evaluators, keep our freedom to choose our own way of being human. This freedom "comes to be something we have to attain if we are to be true and full human beings". 297

However, Taylor admits the two terrains i.e. politics of universalism and politics of difference as being engaged in the identification of the conception of the self, but with different connotations. The politics of universalism should be referred to as a need to recognize the universality of the rational capacity of individuals to determine their own paths to a meaningful life, while the politics of difference pertains to the uniqueness of an individual's or a group's identity. The first account, basically, comes into conflict with the latter and results in exclusivist policies, as it is seen in procedural liberal democracies. ${ }^{298}$ From Taylor's perspective, this conflict derives from the difference-blind-eyes of procedural liberalism which regards the self in light of the principle of autonomy alone. I mean that mere respect for human potential for rational agency would be meaningless without considering man's potential for forming and defining his own identity. While the former involves recognition of equality what makes us the same as one other, the latter involves the recognition of quality that makes us distinct from others. ${ }^{299}$ Indeed, a distinction must be made between two different forms of the recognition of equality. The politics of universalism does not acknowledge the fact that based upon the very principle of autonomy individuals follow their own way of being human beings which is sensitive to

\footnotetext{
${ }^{297}$ Taylor, "The Politics of Recognition," p. 227.

${ }^{298}$ It is always claimed that in liberal democracies the different sub-groups are excluded from the dominant political discourse; a result of which is the sense of common identity and solidarity become weaker and society fragments. It is no wonder, then, if states, especially in multicultural societies, seek to foster a sense of belonging and common identity for the promotion of national identity. In the Canadian political context, the sign of exclusion and dissatisfaction, more particularly in the case of aboriginals, it is seen in the party system, western alienation, regional economic disparities, and intergovernmental conflicts. For detail of this analysis see Stephen Brooks, Canadian Democracy, fifth edition (Oxford: Oxford University Press, 2007). 299 Taylor, "The Politics of Recognition," pp. 233-234.
} 
the particularities of their individual life: "The moral and spiritual order of things must come to us indexed to a personal vision...We are always articulating a personal vision".300 The personal articulation derives from our awareness of our truly individualized and authentic way of being human. This awareness "fits well into the modern understanding of authenticity, with its notion of difference, originality, of the acceptance of diversity" ${ }^{301}$

Having drawn on the suitability of the authentic articulacy within the universal frame of autonomy, toward the middle of "The Politics of Recognition", Taylor opens the debate that in procedural liberalism people in the public sphere must be treated in a difference-blind fashion due to the fact that the relationship of individuals and society is regarded as neutrally determined. In practice, this neutrality results in the renunciation and suppression of culturally different groups. The reason for this claim is that in the public sphere the ontological distinction of peoples is to be ignored in order to further promote social solidarity. Taylor views the politics of the public sphere to be in contrast with the individual's capacity to determine his own particularist understanding of the good life. The politics of difference does not demand a special value for distinctiveness, but rather draws on the very conviction that all human beings are equally capable of initiating their own good life with no distinction. To put it differently, if individuals are true to themselves, they direct their own life under the auspices of the distinctiveness in their identity. The politics of the public sphere rejects the fact that individuals are true to themselves. Taylor explains:

There is, of course, a universalist basis to this as well, making for the overlap and confusion between the two. Everyone should be recognized for his or her unique

\footnotetext{
${ }^{300}$ Taylor, Sources of the Self, p. 428. He repeats the same assertion elsewhere. See Charles Taylor, The Ethics of Authenticity (Cambridge: Harvard University Press, 1991), p. 89.

301 lbid., p. 33.
} 
identity. But recognition here means something else. With the politics of equal dignity, what is established is meant to be universally the same, an ideal basket of rights and immunities; with the politics of difference, what we are asked to recognize is the unique identity of this individual or group, its distinctness from everybody else. The idea is that it is precisely this distinctness that has been ignored, glossed over, assimilated to a dominant or majority identity. And this assimilation is the cardinal sin against the ideal of authenticity. ${ }^{302}$

Accordingly, the politics of difference celebrates the moral value of authenticity, which is itself the offspring of the originality of the will (the autonomous reason) of individuals. This (strong) interpretation of the relationship between autonomy and authenticity requires both the recognition of the equal value of individual autonomy (the politics of universalism) and recognition of the equal value of individual authenticity (the politics of difference). Within this interpretive account of the self, the issue of recognition is related not only to individual autonomy, but also to what man has made of his autonomy: "I want to speak of ...the worth, or weight, or substance of my life ... of how I am 'placed' or 'situated' in relation to the good, or whether I am in 'contact' with it". ${ }^{303}$ It would be consistent to suggest, then, that the two conceptions of autonomy and authenticity are the two faces of the same coin. Therefore, the politics of universalism cannot be ignorant of difference, if it is to do justice to autonomy. By the same token, procedural liberalism cannot be neutral to the fact that individuals in a society, due to their autonomy, may identify their own concept of the good life differently. That is to argue that for each person there is a certain way of being human that is his way. "I am called upon to live my life in this way ... being true to myself means being true to my originality and that is something only I can articulate and discover". ${ }^{304}$ Since the politics of universalism ignores this as a truth to being human, it distorts the life of different others.

\footnotetext{
302 Taylor, "The Politics of Recognition," pp. 233-34.

303 Taylor, Source of the Self, p. 42.

${ }^{304}$ Charles Taylor, The Ethics of Authenticity (Cambridge: Harvard University Press, 1991), p. 29.
} 
As a matter of fact, misrecognition or non-recognition of a distinctive people - or group of peoples - results in the entire renunciation of their autonomy.

The claim is that the supposedly neutral set of difference-blind principles of the politics of equal dignity is in fact a reflection of one hegemonic culture. As it turns out, then, only the minority or suppressed cultures are being forced to take alien form. Consequently, the supposedly fair and difference-blind society is not only inhuman (because suppressing identity) but also, in a subtle and unconscious way, itself highly discriminatory. ${ }^{305}$

Still, it is not clear how to balance the principle of autonomy with authenticity in a practical arena. When someone performs an action that is valuable for her, for example, she certainly claims that her action is right because it has been done based on her autonomy which is true for herself. A paradox appears here. The decision to perform the preferred action is a matter of choice, and is a response to the innateness of the person. But, the value of the action is evaluated by the judgment of those who are related to that action. The question posed here is how to define the relationship of the action of the self and the judgment of those who, due to sharing a communal life, evaluate that action ${ }^{306}$. In other words, how are we to precisely define authenticity in terms of autonomy? More specially, if the action is not desirable for her fellow humans, the judgment about the value of the action becomes more complex. The point of the argument is that she pursues her self-definition and the authenticity of her identity; something that has been true to herself. But, as a member of her society, she should have harmonized her action with the requirements of her society, or she should have withdrawn from her authenticity and lost her autonomy. Then, it is not clear how to justify the moral acceptability (recognition) of

\footnotetext{
305 Taylor, "The Politics of Recognition," pp. 236-37.

${ }^{306}$ For a full account of this line of reasoning see Maeve Cooke, "Realizing the Post-Conventional Self,"

Philosophy and Social Criticism 20, no. 112 (1994): 87-101, and Maeve Cooke, "Authen ticity and Autonomy: Taylor, Habermas and the Politics of Recognition," Political Theory 25, no. 2 (April 1997): 258-88.
} 
such an action, yet keep the authenticity as its impulse. It seems that connecting the two politics is not an easy task.

Admittedly, if Taylor's interpretation of difference is entangled with what he defines as the originality of the individual's actions, the above-mentioned question might remain unanswered. But, if recognition of difference is viewed as a determinant factor in the formation of identity, then we understand the ways through which the person's authenticity of her action is harmonized with the evaluation of the others. Still, by a deeper reading of Taylor, the complexity of both assumptions will become clearer. In the first interpretation, Taylor argues that we have such moral reactions as respect for life, integrity, or the well-being of others. These reactions "are uncommonly deep, powerful, and universal". They are "so deep that we are tempted to think of them as rooted in instinct, in contrast to other moral reactions which seem very much the consequence of upbringing and education". ${ }^{307}$ We share those deep moral reactions with others, because it seems that we instinctively understand them regardless of our different backgrounds. Although our identity is defined through our interaction with others, and although our identity changes over the historical background, we still have something in common with others. We are all in search of something that makes us members of the single and cosmopolitan unified family of being. This thing is the sense of being human. It is "our sense of the unity of the person". ${ }^{308}$ We are all human beings, so, we act from a point that is instinctively familiar and acceptable for us all. Based on this formulation of moral commitment, liberalism suggests morality not to be restricted to distinctive identities. Hence, it closes its eye toward ontological differences.

\footnotetext{
${ }^{307}$ Taylor, Sources of the Self, pp. 4-5.
}

${ }^{308}$ Ibid., p. 112. 
In sum, concrete social relations convince us to query how we know that we have the same sense of being human as others, and how we can reconcile the very sense of being human with our different backgrounds, impulses behind our behaviour, our tastes, and worldviews and so on. How, then, do we understand those who might have their sense of being human different from us? The answer to this question prompts us toward the second mentioned interpretation: we discover our identity and our sense of being human not in isolation but that we negotiate it through dialogue with others. We are selfinterpreting social animals committed to the evaluation of our conception of the good life in an interchange with others. Through such dialogue and contact with others our identity is formed or malformed. We dialogue with others and in so doing we get to the deepest level of our potential to articulate what makes our characters as human beings. We interpret our sense of being human and what is significant to us through dialogue with others. Dialogue harmonizes our actions with others, and hence identifies who we are. In what follows I delve into further detail of dialogue as means of identification of the selfhood and its relationship with recognition.

\section{Dialogue over Recognition of Identity}

By arguing that we are dialogical selves and that our identity is formed through open dialogue, Taylor consistently moves away from the Hegelian conception of intersubjective identity toward a new phase in the articulation of the politics of recognition. In this movement, a political ontology is articulated that celebrates the interactive component of individual identity-formation. By dialogue we become selves "The individual is an other before he is a self. It is in addressing himself in the role of an 
other that his self raises in experience". ${ }^{309}$ That is to say that our identity is defined within a network of interlocution with those who like us, and are part of a whole framework of interlocution. In this framework, the sense of "I" is extended to everybody, who is trying to have the same sense. Therefore, our sense of individual person is interpreted in a wide perspective to embrace all different others who struggle for the same sense. Here, Taylor exposes his communitarian insight by advancing the thesis that the competing senses of selfhood on behalf of different selves and their different notions of the good life are harmonized through dialogue over recognition without urging for a univocal conception of a good society. Thus, Taylor argues, "discovering my own identity doesn't mean that I work it out in isolation, but that I negotiate it through dialogue, partly overt, partly internal, with others". 310

The conception of dialogue is of crucial importance in the understanding of the theory of recognition. Taylor distinguishes two levels in dialogue. At the intimate level, we understand ourselves through our own authentic lenses of who we are with full potential. That is to confirm that our identity can be formed through the course of our contact with others. In this level, we see how much an original identity is vulnerable to recognition given or withheld by significant others. Intimacy is a dialogical phenomenon. That is a matter of what we share, of what is for us, Taylor argues. "We could never describe what it is to be on an intimate footing with someone in terms of monological states". ${ }^{111}$ But, we also understand that we need to go beyond this intimate sphere - let's use Rousseau's language of amour de soi (love of self) - in order to develop our potential as human

\footnotetext{
${ }^{309}$ George Herbert Mead, Mind, Self, and Society from the Standpoint of a Social Behaviorist (Chıcago: University of Chicago Press, 1934), p. 168.

${ }^{310}$ Taylor, "The Politics of Recognition," p. 231.

${ }^{311}$ Taylor, "Liberal-Communitarian Debate," in Philosophical Arguments, p 190
} 
beings. We know that our sense of the selfhood is "taking place in a continuing dialogue and struggle with significant others" ${ }^{312}$ We understand that through a move from the intimate sphere - the original way of discovering ourselves - toward a social sphere which is through language and contact with significant others - we flourish. Indeed, it is through "the mover from the for-me-and-you to the for-us"313 that we discover ourselves as social beings.

Having this explanation in mind we can now get closer to understanding the relationship between the sense of "me" and the common evaluation of my actions by others in the social context. Here, we become closer to understanding of Taylor's idea that the formation of identity belongs to our intimate sphere, to our own authentic path to a meaningful life, but that this is developed in the course of dialogue and deliberation with others, through which we are recognized as distinct individual human beings: "General recognition was built into the socially derived identity by virtue of the very fact that it was based on social categories that everybody took for granted". 314 Evidently, in the framework of interlocution the liberal conception of neutrality is replaced with a conception of society that allows particular identities to flourish.

The dialogue, therefore, refers to two sorts of deliberation. One is the dialogue with others in the network of interlocutors over the formation of our identity. This conception is a crucial feature of our human life and provides us with the acquisition of a sense of full human agency. In The Ethics of Authenticity, Taylor makes a radical claim

\footnotetext{
312 Taylor, "The Politics of Recognition," p. 233.

313 Tbid.

${ }^{314}$ Taylor blames the modern philosophy arguing that the relationship of identity and recognition which is the crucial feature of our human condition has been rendered almost invisible because of the monological bent of the modern philosophy. See also ibid., p. 229-30.
} 
stating that we only become capable of understanding ourselves and defining our identity through dialogue. He argues that humans are fundamentally dialogical creatures, developed into their individualizations through interaction with others. ${ }^{315}$ Implying a mutual interdependence, this dialogical characteristic is not antithetical to one's ability to achieve individuality, but is rather a crucial aspect of it. One becomes an authentic human being only when one creates a dialogical relationship with others. With dialogue, how can we move from the intimate sphere to the public level in which we extend our identity? Without the exchange with interlocutors we do not learn the language for our selfdefinition. Dialogue in this sense is viewed as a kind of deliberation for achieving a common space, where people recognize each other as individuals and also recognize the differences that identified their distinctiveness. Taylor contends that we are aware of this dialogical character because it is a distinct feature of our mind: "The genesis of human mind is in this sense not monological, not something each person accomplishes on his or her own, but dialogical". ${ }^{316}$ Our mind produces an authentic relationship with ourselves, and then proceeds into a struggle to have our identities recognized by others who are dialoguing for the same purpose.

An important implication of the dialogical understanding of the self is that the self is not to be viewed in terms of mere rationality. Rather, we are required to enlarge our vision of identifying the self in order to embrace the possibility of our shared meanings and moral values with our interlocutors. This characteristic of the self is not only fundamentally different from the perspective of self as a self-reflective agent, but also provides a certain kind of horizon for the dialogical selves to stay in exchange with other

\footnotetext{
315 Taylor, The Ethics of Authenticity, p. 33.

${ }^{316}$ Taylor, "The Politics of Recognition," p. 230.
} 
interlocutors. This second understanding of the characteristics of the self brings about the moral significance of dialogue. It has moral importance because it is about where we are standing and where we are going forward from now on:

What I am suggesting is that we see ourselves as selves, because our morally important self-descriptions push us in this direction or, alternatively, because we identify ourselves with this kind of description. ${ }^{317}$

Dialogue in the social sphere allows us to get into deliberation with our interlocutors over the moral values and our distinct concepts of the good life. While in the first intimate level of dialogue we tend to identify ourselves, in this second level of social interchange, we are apt to fulfill our lives. In the first level of dialogue we want to know "who we are" and "where we are coming from", whilst in the second level we are looking for our place in social life. We want to know where we, as dialogical selves, are standing in relation to our interlocutors. This second-level dialogue takes place in a moral space. It is a moral space because it is all about the deliberation among dialogical selves over a conception of society in which particularities can flourish. It is indeed "the background against which our tastes and desires and opinions and aspirations make sense". ${ }^{318}$ If the background is ignored, people are forced into a homogeneous mould that is untrue to them. ${ }^{319}$ This homogeneity exhibits the dissolution of other cultures, a hegemonic culture denying any kind of dialogue over mutual recognition. This creates the most serious problem of our times; social exclusion, which leads to oppression of different others.

Accordingly, dialogue - in both intimate and social spheres - is a critical theme in the definition of identity and therefore in the politics of difference. If recognition is to be

\footnotetext{
${ }^{317}$ Taylor, "The Dialogical Self," in The Interpretive Turn: Philosophy, Science, and Culture, David R. Hiley, James F. Bohman, and Rich ard Shusterman ed. (Ithaca: Cornell University Press, 1991), p. 305. 318 Taylor, "The Politics of Recognition," p. 231.

319 Ibid., p. 236.
} 
taken as the determinant factor in identity formation, dialogue takes precedence over the recognition of identity. As already analyzed, dialogue reflects the crucial feature of our character as human being. At the intimate level of knowing who we are, due to the dialogical character of our mind, we extend the definition of our identity to a framework of interlocution, and at the social level we exchange our conception of the goods with others in order to construct a common identity. For this reason, peoples need to stay in dialogue with one another. This need, according to Taylor, is realized in an ethical space. "The sense of self so defined is something more than the bare reflexive awareness" 320 or continuing subject. It involves the background in which certain things matter to us. We cannot define our identity except through the background and the dialogical process in which things matter to us. ${ }^{321}$

It follows from such a conception of dialogue that identity is a matter of culturally mediated self-definition, yet is practically relevant to one's orientation in life. Social life requires man to stay in a dialogical relationship with his fellow human beings in order to undertake practices needed for such life. Insofar as "much of our understanding of self, society, and world are carried in practices that consist in dialogical action", 322 the notion of identity cannot be defined solely on an individual basis. As a consequence, identity is constructed dialogically both in intimate and social levels. The dialogical conception of the self highlights the moral dimension of the public sphere in which the self becomes subject to changeable circumstances. Taylor confirms this conclusion arguing that authenticity

\footnotetext{
${ }^{320}$ Taylor, "The Dialogical Self," p. 306.

321 Taylor, The Ethics of Authenticity, p. 40.

322 Taylor, "The Dialogical Self," p. 311.
} 
(knowledge of oneself at the intimate level) and dialogue (knowledge of oneself in interchange with the others) are not contradictory:

We cannot understand human life merely in terms of individual subjects, who frame representations about and respond to others, because a great deal of human action happens only insofar as the agent understands and constitutes himself or herself as integrally part of a 'we'.323

In conclusion, the conception of dialogical self is associated with the moral framework through which one fulfills his life in light of the normative values that make him human. These values give ethical significance to the formation of the selfhood through connections made between the self and his interlocutors. Having the importance of dialogue in the formation of identity, I arrive at the conclusion that on the intimate level - the first contact of one with oneself or the solitary exploration of oneself - no sense of value with regard to one's relation to others is attained. Rather, it is in the social context, in the framework of interlocution that one moves toward attaining his identity, especially his moral selfhood. Indeed, the process of discovering the selfhood takes place through dialogue within the framework of interlocutions and moral evaluation. In other words, we discover our true identity and our original way of being human through negotiating with our interlocutors, who, the same as us are in full contact with themselves and others. Through this interconnecting process of self-expression, mutual dialogue, and recognition of self-fulfilled identity is formed.

Given the importance of such interconnections, being narcissistically reluctant to enter into dialogue with one another inflicts a double harm. That is to say that not only is one's selfhood not flourishing, but the other's identity is also humiliated, misrecognized, and even oppressed. According to Taylor, we may develop our own opinions and outlooks

\footnotetext{
${ }^{323}$ Taylor, The Ethics of Authenticity, p. 41.
} 
to a certain degree through solitary reflect, but in important issues such as our identity we define it through dialogue. "We define this always in dialogue with, sometimes in struggle against, the identities our significant others want to recognize in us". ${ }^{324}$ Dialogue is, therefore, a means of mutual recognition of identity. To put it more clearly, unwillingness to dialogue in social sphere is the source of misrecognition and therefore social exclusion. Evidently, if one is withheld from dialogue and is prevented from enjoying due respect for his authentic identity by others, who insist monologue as the means of social realization, one is rendered unable to achieve one's self-realization. In this way, the most grievous wound to the selfhood is inflicted, which saddles its victims with a crippling self-hatred. ${ }^{325}$ In light of this argument, I suggest recognition to be regarded as the true source of inspiration for a more promising approach to justice.

\section{A Recognition-based Approach to Social Justice}

Developing the thesis that one's identity is formed by recognition, prompts us to argue that the issue of recognition is not merely related to identity, but also is a matter of social justice. From a Taylorian perspective, recognition is essentially a matter of selfrealization, moral evaluation, and a quest for the good life and not necessarily a matter of justice. ${ }^{326}$ Although we cannot deny the inextricable relationship of misrecognition as a matter of identity with misrecognition as a question related to social status, the fact is that Taylor is mostly preoccupied with the former since it is a true case of the latter. In a

\footnotetext{
${ }^{324}$ Taylor, The Ethics of Authenticity, p. 33.

325 Taylor, "The Politics of Recognition," p. 232.

326 Having depicted the characteristic of man as fundamentally dialogical and establishing that man's life is dialogical in character, Taylor then advances the thesis that all human beings live is a public framework of "questions about strongly valued goods". These goods are a product of strong evaluation in the area of what is morally good or bad, rights or wrong, and so on. In this way in his account of recognition the issue of moral evaluation is a key theme. See Taylor, Sources of the Self, pp. 31-33
} 
variety of writings, Taylor gives a typical narration of the self articulating of how we think of ourselves, as selves, and why we draw upon various theories to understand ourselves as human beings. However, his account of the dialogical self suggests the possibility of crossing the boundaries between recognition as the substance of identity and recognition as a matter of justice. In this sense, selfhood is especially a notion that highlights what should be done in order to recognize publicly different others, who the same as us express themselves in accordance with their own evaluative framework and horizon of meanings. Correspondingly, the selfhood is interrelated to the conception of the moral life and via which to justice in the ethical life-world: "Selfhood and the good, or in another way selfhood and morality, turn out to be inextricably intertwined themes". ${ }^{327}$ Using this passage, I draw on the relationship between the moral life as a pathway to recognition and justice.

The relationship of selfhood and morality lies in the strong evaluations being made by human beings in the inescapable frameworks. I mean inescapable because our identity is formed within a framework of dialogue and evaluation with our interlocutors. In other words, such framework is like the horizon within which we are enabled to take a stand and make our judgment. Indeed, human agents in everyday life inevitably act and react as if some things were good and higher versus others, which are bad and lower and as if the goals we pursue were worthwhile, and as if our ethical statements were capable of being correct. Such moral evaluation among the diverse conceptions of the good life is the most

\footnotetext{
${ }^{327}$ Taylor, Sources of the Self, p. 3.
} 
important feature of identity. Moral evaluations are not the mere expressions of our subjective sentiments; they are rather genuine judgements concerning good and bad. ${ }^{328}$

From this perspective, identity is seen to be developed in accordance with cultural horizons and the backgrounds which have been developed differently. Yet, the moral frameworks through which we evaluate our moral values form our desires, inclinations, or choices, are not entirely changed in different backgrounds. These moral values are essentially different from weakly evaluated goods; they are strong evaluative goods "by their special status they command our awe, respect and admiration". ${ }^{329}$ This is similar to a universal moral law, which has been transferred to different directions in the modern moral world. However, we have still kept the "sense of ourselves as commanding (attitudinal) respect"330. It is then true that the universal principle of humanity commands respect for fellow beings as humans, but the embodiment of this principle is reliant on people's awareness. Reminiscent of Kant's ethics of duty, Taylor explains this moral principle arguing that we ought to do our moral duty not because it is admirable, or a lovely thing, or valuable in itself, but rather because it is our duty to do so morally. 331

Evidently, evaluation among a plural set of values, as a pathway in the construction of the self, does not reflect subjectivism or projectivism. That is to claim that we evaluate because evaluations are just projections of our sentiments - emotions, reactions, attitudes, commendations - in a value-neutral world. Nor do our evaluations reduce universal injunctions at both individual and group levels of awareness. In all these

\footnotetext{
${ }^{328}$ Taylor, "What is Human Agency," pp. 15-44.

${ }^{329}$ Taylor, Sources of the Self, p. 20.

${ }^{330}$ Ibid., p. 15.

${ }^{331}$ Taylor, "A Most Peculiar Institution," in World, Mind and Ethics: Essays on the Ethical Philosophy of Bernard Williams, J. E. J. Altham and Ross Harrison ed. (Cambridge: Cambridge University Press, 1995), p. 145.
} 
fashions such moral judgments as good or evil, true or false, and right or wrong are rather a projection of man's own subjective preference. Taylor undoubtedly discredits all of those relativist accounts because we cannot free ourselves from the questions that are central in understanding of the real nature of human being and about valid ethical standards ${ }^{332}$. There are certainly objective values in our decisions that "allow us to understand and make sense of the actions and feelings of ourselves and others", ${ }^{333}$ but, how does relativism really do justice to our real moral experience? In a moral life, there are features independent of our desires, choices, and inclinations that are most salient; features by which we intrinsically construe as our identity. In everyday life we are involved in deliberations of higher, better, or more worthwhile things that are genuine aspects of our life, even though they might contrast with our weakly evaluated goods (our inclinations). Such deliberations are central features of our identities as human beings. Projectivism might justify some moral judgments in terms of personal and group preferences, but cannot incorporate them into universal moral injunctions.

Arguably, the relationship of universally accepted moral values and contextually deliberated values is paradoxical. The paradox lies in the fact that individuals constantly face multiple goods that are seemingly irreconcilable with one another. "There is no guarantee that universally valid goods should be perfectly combinable, and certainly not in all situations" ${ }^{334}$ If this is so, then does it not mean that individuals as, authentic selves, can choose from a range of moral values? The act of choosing from a setting of plural values makes the individual selves authentically different. Individuals need to choose

\footnotetext{
${ }^{332}$ Taylor, Sources of the Self, p. 60. Also, Taylor, Malaises of Modernity, pp. 18-19.

${ }^{333}$ Taylor, Sources of the Self, p. 57.

334 Ibid., p. 61.
} 
moral values in a plural world because they are in a situation of conflict between moral demands, which seem to them irreducible, but at the same time un-combinable.

If there seems to us no conflict in our moral world, that is because our sympathies for some values or our moral horizons are too narrow. More particularly, we might be easily satisfied with pseudo-solutions in the realm of conflicting values. ${ }^{335}$

At this stage, the questions we face are: How to respect the intrinsic values that are common to all of us, while simultaneously discriminate among a plurality of values in our ordinary life? And, how do we recognize each other's acts of discrimination among moral values? Taylor suggests a strong evaluation approach in addressing these questions: an approach that clarifies the key importance of moral evaluation in the politics of recognition. In his approach, moral values are divided into three groups: some are universal, others are obtainable within a more limited collectivity such as the nation, and the third group is more particular to cultures or groups. ${ }^{336}$ The last group of moral values, which cause confusion on the importance of a moral framework, is distinguishable by a certain kind of weak evaluation. Weak evaluations are quantitative and are concerned with outcomes and never engage with qualitative distinction of worth. Indeed, weak evaluation for something to be judged good, to be deserved is sufficient. But in the strong evaluation there is a use of good for which being desired is not sufficient. Indeed, the essence of strong evaluation derives from when we condemn something or an action in spite of our emotion to it. ${ }^{337}$ Deeper evaluation is something beyond our desires. The weak evaluation reflects an account of how individuals believe that certain goods deserve worth and should be affirmed with no attachment to higher concepts related to deep

\footnotetext{
335 Taylor, "Reply and Re-articulation," in Philosophy in an Age of Pluralism, p. 216.

${ }^{336}$ Taylor, Philosophical Papers, p. 244.

${ }^{337}$ Charles Taylor, "What is Human Agency," in Human Agency and Language: Philosophical Papers, Vol.

1(Cambridge: Cambridge University Press, 1985), pp. 18, 28, 34, and 66.
} 
meaning life we consider essential to humanity. It urges the withdrawal from ontological commitments and extraction from a variety of epistemological, ethno-political and metaphilosophical considerations. ${ }^{338}$

Quite the opposite, a strong interpretation of moral values understands all existing goods independent of human beings. Smith argues that this kind of interpretation accounts for an avoidable moral realism versus those of weakly evaluated values that met our routinely desired goods. As he points out:

If truth is understood as a matter of disclosure between contrasting interpretations, and the favoured interpretation is articulated in a vocabulary of evaluative significance, then truth will also be describable in evaluatively significant terms. For strong hermeneutics, such moral realism is unavoidable. 339

Thus, strong hermeneutics offers an alternative to inadequately weak interpretation of moral values. It clarifies the insight that as selves, we cannot abstract ourselves from our strongly evaluative commitments toward worthwhile moral goods. Such commitments are fundamental to our identity, and are undoubtedly the necessary components of our undamaged human personhood. ${ }^{340}$

The existence of goods by looking at the subject of our strong evaluation, brings about the issue of hypergoods ${ }^{341}$. Hypergoods are goods that are not only "incomparably more important than others but provide the standpoint from which these must be weighed, judged, and decided about". ${ }^{342}$ They are obviously irreducibly social goods that constitute our moral being, hence they cannot be dismissed without self-deception and

\footnotetext{
${ }^{338}$ Nick Smith, "Charles Taylor, Strong Hermeneutics and the Politics of Difference," Radical Philosophy 8 (Autumn 1994): 20.

${ }^{339}$ Smith, “Charles Taylor, Strong Hermeneutics and the Politics of Difference," p. 21.

${ }^{340}$ Taylor, Sources of the Self, p. 27.

${ }^{341}$ Ibid., p. 64.

${ }^{342}$ Ibid., p. 63.
} 
logical contradiction. ${ }^{343}$ Therefore, they can be decomposed into an individual projection of life or be expressed in terms of projectivism. Good examples of hypergoods are the ideas of universal justice and/or benevolence which transcend all social systems. Nevertheless, even the notion of universal justice, for example, might be highly equivocal, for it is a vague conception referring to different things in different perspectives. For example, justice might be seen in terms of the distribution or re-distribution of social goods (Rawls's view), or removing cultural obstacles for the purpose of equality (social justice in Fraser's insight), or it might be seen as the offspring of the recognition of difference (recognition as justice). Hence, the notion of justice, as an example of a hypergood, is itself prone to awareness of one's own understanding of it. However, there is no doubt that we, though disagreeing about hypergoods, are standing within an inescapable framework that provides the background, either implicit or explicit, for our moral judgment. Difference in backgrounds and the horizons of meaning by no means diminishes the importance of inescapable frameworks. In this paradoxical status, the suggestion is to rank hypergoods in terms of the things that gives us our sense of dignity and deep life, because only a state of narcissism and disordered personality disregard the cardinal importance of the dignity of life..$^{344}$

Accordingly, if we are required to choose among the plurality of goods, our choice should be in accordance with a conception of the good life. But, this conception of the good life is different from "life goods". It extends beyond the components of the "life goods", for example, freedom, reason, and benevolence that make life worth living. There must be some goods with deeper values. There must be a higher perspective that

\footnotetext{
${ }^{343}$ Charles Taylor, "Irreducibly Social Goods," in Philosophical Argument, pp. 127-145.

344 Taylor, Sources of the Self, p. 28.
} 
empowers us to do and be good, a good that is a constitutive good by which we move closer to it, to know it, to love it, and to live for it:

The constitutive good does more than just define the content of moral theory. Love of it is what empowers us to be good. And hence also loving it is part of what it is to be a good human being. This is now part of the content of the moral theory as well, which includes injunctions not only to act in certain ways and to exhibit certain moral qualities but also to love what is good. ${ }^{345}$

We might follow the requirement of the "life goods" and qualitatively illustrate the significance of conceptions, such as freedom or equality. We might also distinguish between actions, feelings, inclinations, or distinct modes of life that characterize the components of a good life. However, there are "constitutive goods" that are superior to these "life goods". The constitutive goods confer meaning, depth, and importance to our lives. The constitutive goods such as God, or the ideal good of Plato, or Kant's principle of humanity, command our moral awe and empower us to be constantly good. ${ }^{346}$ To be sure, the constitutive goods should not be external if they are to be considered moral sources. A constitutive good, according to Taylor, shows what constitutes an admirable life:

The constitutive good does more than just define the content of the moral theory. Love of it is what empowers us to be good. And hence also loving it is part of what it is to be good human being. This is now part of the content of the moral theory as well, which includes injunctions not only to act in certain ways and to exhibit certain moral qualities but also to love what is good. ${ }^{347}$

The importance of the constitutive goods for an admirable life is beyond question. Yet, we do not know how culturally different peoples, particularly in the case that the shared background of significance is missing, might admire the same value. Taking one example from Taylor is useful to further clarify this question. Referring to the case of Rushdie's Satanic Verses, Taylor wonders whether the Western conception of a

\footnotetext{
345 Taylor, Sources of the Self, p. 93.

${ }^{346}$ Charles Taylor, "Comments and Replies," Inquiry 34 (1991): 243.

${ }^{347}$ Taylor, Sources of the Self, p. 93.
} 
constitutive good meets the mainstream Islamic vision of the highest good. Then, the focus of controversy is not whether there is a lack of a shared vision in the two different cultures; nor is it the fact that Western societies allow culturally different groups to survive in a democratic framework. Rather, the point of controversy, according to Taylor, is that the worth of culturally different groups is not acknowledged, nor is the equal value of their cultures recognized ${ }^{348}$ Both sides in this controversy might have the same idea of the quality of human dignity - and the derivative notion of the freedom of expression but they understand it in two fundamentally distinct horizons of articulation. Therefore, once a clash appears between culturally different groups, its cause should be searched for in their different modes of ethical articulacy. To prevent this kind of clash, a certain vision of the good life should be formulated that acknowledges the plurality of different moral values or social goods. This vision must underlie moral reactions, affinities, and aspirations of culturally different groups. ${ }^{349}$ For this aim, the articulation must be grounded on historical backgrounds, the horizons of meaning, and the linguistic contexts that form the identity of that specific group. Indeed, the sources of the two cultures should come closer and ideally fuse. This kind of articulacy is possible, Taylor argues, when:

It makes it plain and evident, in all its inherent force, its capacity to inspire our love, respect, or allegiance. An effective articulation releases this force, and this is how words have power. ${ }^{350}$

Through the ethics of articulacy, we arrive at a major argument about the recognition of difference. If there exists the multiple goods, there should also exist

\footnotetext{
${ }^{348}$ Taylor, "The Politics of Recognition," p. 250.

${ }^{349}$ Peter McCormick, "Understanding Modernity," Eleutheria, 2, no.1 (Spring 1989): 13.

${ }^{350}$ Taylor, Sources of the Self, p. 96.
} 
multiple evaluations and diverse articulations of those goods. This reasoning convinces us to confirm that we, as a consequence, must recognize the sense of distinctiveness of culturally different groups as their rights. ${ }^{351}$ These rights are justified in light of the very recognition of the fact that they follow their own authentic vision of the good life. This brings us to the conclusion that we share our conceptions of the constitutive goods through the strong evaluation of what fulfills our lives. We know that the constitutive goods guide us toward a conception of the good life marked by depth and meaning. And, we share the idea that to achieve a good life we ought to do our moral duty. We share these ideas because they seem to have roots in our instinct. However, we also know that those strongly evaluated goods are manifested in distinct cultures differently. Further, we know that if a conception of the good is ranked above other recognized goods, the worth of peoples belonging to those goods is denied. Denial and/or misrecognition of those who desire different conceptions of goods then undoubtedly come to be the cause of unjust social structures.

Resting on this interpretation of the strong evaluation, we can move from the understanding of recognition of difference as a determinant factor in the definition of identity towards a recognition-based conception of justice - recognition as justice. What is required in advancing the idea of recognition as justice is the public recognition of the equal value of those cultures. ${ }^{352}$ Otherwise, there is no public recognition and culturally different identities are deprived of their conception of the good life. Unwillingness to publicly recognize different others and their cultural values, doubtlessly inflict harm, social exclusion and oppression. Therefore, recognition of difference comes to be an 
intellectual grounding for social justice. Recognition as Justice orients the focus of inquiry beyond the issue of the damaged identities of minorities, subaltern, and marginalized groups. It provides answers to the questions of how to do justice to those who have been oppressed because of their different concepts of the good life, and how to include them in social discourse without abstracting them from their distinctiveness.

\section{Recognition and Socio-Political Solidarity}

Having provided the basis for an alternative framework for a social conception of justice, the politics of recognition implies a third factor: the recognition of difference must have a potential impact for solidarity in multicultural and multiethnic societies. This third interpretation of recognition comes to the fore when the question of harmonizing a just relationship among a range of distinct cultures - the coherent communal ties - is raised. Taylor is provocative by suggesting that the recognition of particular communal attachments inspires social solidarity ${ }^{353}$. The solidarity refers to here is beyond recognition of individual rights and requires that individuals be recognized as belonging to community of vales. It is indeed a matter of concrete solidarity attained through social practices of mutual recognition, involvement, and support. Recognition as justice, and by implication, as a way to social solidarity is a matter of care enabling participation with a positive approach to inclusion in social discourse. Here, Taylor's intuition prompts our thought: "Our understanding of the good things in life can be transformed by our enjoying them in common with people we love". ${ }^{354}$ Even our understanding of "who we are" depends partly on how we share it with our interlocutors within evaluative frameworks.

\footnotetext{
${ }^{353}$ Charles Taylor, "Cross-Purpose: The Liberal Communitarian Debate," in Philosophical Arguments, op. cit, pp. 181-203.

354 Taylor, "The Politics of Recognition," pp. 230-31.
} 
From this perspective, we recognize cultural differences as the essential feature of identity; a feature that is a necessity of the politics of universalism.

Once recognition is accomplished, interlocutors further learn their cultural specification from one another. This engagement in learning enriches all participants in the process of public deliberation; it also enhances the level of social understanding and as a result strengthens solidarity. ${ }^{355}$ In maintaining the advantage of this model of social solidarity, we deliberately promote our course of interchange with co-locators and arrive at the threshold of just judgment about the values of different cultures. The original point of this approach to solidarity is that our judgment is extended beyond the mere issue of respect and toleration. It rather contains the acknowledgement that "all human cultures that have animated whole societies over some considerable stretch of time have something important to say to all human beings". 356 Interestingly, the process of learning provokes us to move to a broader - normative - horizon of understanding that we could not possibly have had at the beginning. Indeed, the process of learning about other cultures prevents narrow judgment and prejudice; even encourages us to give our judgment about the value of other cultures through the transforming of our standards.

To have a better sense of the relationship of recognition and solidarity, we can draw on Gadamer's approach to understanding of the other as "fusion of horizon"; the fusion of stand points of two different persons. "Fusion of horizons" reflects "the range of vision that includes everything that can be seen from a particular vantage point". 357 Different horizons of understanding - prejudices and pre-judgments - are fused when

\footnotetext{
355 Taylor, "The Politics of Recognition," p. 153.

356 Ibid., p. 252.

${ }^{357}$ Hans-George Gadamer, Truth and Method, Joel Weinsheimer and Donald G. Marshall trans. (New York: Continuum, 1975 ), p. 301.
} 
different persons come into a dialogue to understand a horizon that is not their own in relation to their own. The dialogue must come into a mutual understanding, that is to say that dialogue would be successful if it ends at agreement and mutual recognition. In the dialogue "what is to be grasped is the substantive rightness of his opinion, so that they can be at one with each other on the subject". ${ }^{358}$ Indeed, by dialogue we seek to discover other peoples' standpoint and horizon of understanding. This happens when we continually examine our own present horizon of understanding and place it at the view of our interlocutor. An important part of that examination is the encounter with the past and the understanding of the background from which we come..$^{359}$ The "fusion of horizons" goes on and grows through such examination of our own horizon of meaning and bring it to other's horizon of understanding.

"Fusion of horizons", therefore, entails dialogue, understanding, and recognition of the distinctive others. To attain an understanding of different cultures and forging a common language about something that common to all participants in dialogue, their unique contributions to the whole of culture should be appreciated. In order to appreciate, we need to learn how to enter into a mutual understanding. Through learning, we exercise new vocabularies that assist us in a deeper understanding of others, and thereby transform our standards of the life-world into a commonly accepted life-world. This transformation results in a certain political outlook serving solidarity in socio- politically fragmenting societies.

In conclusion, Taylor's account of recognition has been developed based on an interactive component of identity formation through dialogue. We embark in dialogue

\footnotetext{
${ }^{358}$ Gadamer, Truth and Method, p. 387.

359 Ibid., p. 305.
} 
with others in order to mutually recognize one another. We want to know who we are, so do others. In addition, our identity achieves fullness with the life-world and with significant other. In this sense, dialogue is firmly tied to the conception of recognition. If the openness of dialogical processes is ignored, the authentic manner of identity formation, and in so doing the recognition of identity, is distorted. Therefore, cultural influences imposed on dialogical participants from the outside would be a form of misrecognition; and, misrecognition, Taylor argues, is oppression. At this point the recognition of difference comes to be a theory of justice; a recognition-based theory of justice versus a rights-based theory of justice. The recognition-based theory of justice, in turn, curves social cleavage and political fragmentation. To rephrase this concisely, on Taylor's account, recognition is 1) the determinant factor in the formation of identity; 2) the basis of a recognition-based and multicultural approach to justice; and 3) it is one of the most important sources of social solidarity. These three components in the Taylorian account of recognition, I argue in the following chapter, can be the source of an ethics of recognition in an age of globalization and exclusion. 


\title{
Chapter 4
}

\section{Toward An Ethics of Recognition in International Relations}

We intellectuals can do something positive by first of all doing something negative, we can stop holding out the hope that there is a new alternative global way and stop refusing to admit that the older one is unworkable. A lot of us are being paralyzed by thinking that we still should provide a global alternative. After we have abandoned that position we can play our part depending on what expertise we have in this or that area in building up a raft of creative measures that will not be the same in every country. That is what remains.

\begin{abstract}
Charles Taylor, "On Identity, Alienation and the Consequences of September $11^{\text {th }}$. An Interview with Charles Taylor", pp. 165-66.
\end{abstract}

The theory of recognition is important for theorizing International Relations in three specific but interrelated ways. The first refers to the political acknowledgment of the equality of different others within their own cultural context and national discourse. Recognition in this sense, I suggest, should be interpreted based on a categorical reason to promote the idea that political recognition of states is a vital need for the establishment of a just world. ${ }^{360}$ All different nations are to be treated equally as long as they respect and practice this categorical model of behaviour in the life-world. This interpretation of recognition is not new since it has long been the point of controversy in the life-world. For example, Hans Kelsen in his illuminating article entitled "Recognition in International Law: Theoretical Observations", distinguishes between the two "legal" and "political"

\footnotetext{
360 I use the term categorical reason to stress the undeniable importance of the core human values, which should by no means be violated. As a philosophical lead from Kant, the categorical reason comes to be a model of behaviour in the life-world tending to preserve human beings versus the dominant accounts of international relations. The categorical interpretation of the principle of a just behavior encourages setting the idea of the political recognition of equality as the basis of a just world order. The precedence of the importance given to the value of a human being over international order can be found in article 28 of the Universal Declaration of Human Rights and article 2 of the Charter of the United Nations; this clearly reveals the underlying weight of the categorical interpretation of the rules and principles of the life-world.
} 
expressions of recognition. The former is an act of "cognition" implying the conception of the statehood. The latter is an expression of willingness to politically recognize and take the measures to perform obligations derived from the very legal recognition. ${ }^{361}$ The latter, illuminates the importance of willingness to recognize the equality of the members of international society as a categorical norm. The terms of membership in the United Nations, for instance, imply that all members of the international community have equal status irrespective of the historical development of their statehood and national identity formation as long as they behave based on the categorical reason, especially in line with the peace-loving principle articulated in the charter of the United Nations. ${ }^{362}$

Recognition brings about the importance of addressing power due to the unwillingness of some states to recognize different others. I draw on this unwillingness as a property of agency, or the disposition of more powerful states to recognize others in the existing unbalanced order of the world. ${ }^{363}$ In the sense, power is not limited to possession of or ability to impose something over different others. It is not "an image of power as turning on the fact that some give commands and others obey". ${ }^{364}$ Rather, it has a deeper connotation. It is interpreted as the unwillingness to acknowledge freedom of others'

\footnotetext{
${ }^{361}$ Hans Kelsen, "Recognition in International Law: Theoretical Observations," The American Journal of International Law 35, no. 4 (1941): 605-17.

362 The UN Charter, article 4.1: Membership in the United Nations is open to all other peace-loving states which accept the obligations contained in the present Charter and, in the judgment of the Organization, are able and willing to carry out these obligations.

${ }^{363}$ Habermas views this unwillingness as a question of unbalanced rationality in the Iife-world' in which there is always a different other who is oppressed, negated without ethical consciousness. Interpreting the 'life-world', in terms of actions coordinated by more powerful agents, we can observe a picture of the world portrayed in terms of a battle between those who are taking strategic plans to undermine the sense of agency of the weaker nations and resistance and struggle of weaker nations for their rights to be different. To read more about unbalanced rationality see Andrew Edgar, The Philosophy of Habermas (McGill-Queen's Press, 2005), pp. 132-137.

${ }^{364}$ Charles Taylor, "Foucault on Freedom and Truth," in Philosophy and Human Sciences (Cambridge: Cambridge University Press, 1985), p. 158.
} 
interpretation of their own meaningful life. ${ }^{365}$ Power, defined here, extends even beyond the view of discursive power and the knowledge-power relations. Rather, it refers to monological consciousness rejecting dialogue and dialogical wisdom, and consequently negation of different others' horizon of meaning. Power in this sense is accompanied by an inner factor; unwillingness to recognize different others. Mao Zedong in 1958 highlights such unwillingness, when he argues that about forty some countries refuse to recognize China because of American's position. ${ }^{366}$ In recent time, and celebrating the end of the Cold-War, Fukuyama ties recognition with capitalism and liberal democracy; implicitly advancing the nonrecognition of those who do not follow liberal vision of the common good. ${ }^{367}$ Accordingly, political recognition depends heavily on liberation from such unwillingness - the exercise of power, exclusion, and oppression. Nelson Mandela decidedly expresses his nation's aspiration to be released from such oppressive character of the world. Power, therefore, is to be seen as the reluctance to accord a full-fledge political recognition of equal status and participatory parity for the actors of world politics, more particularly non-Western others. Resulting in a deliberate oppressively shaped power; non-recognition negates the others' rights to be the equal participants in the life-world. Therefore, as will be argued shortly, issue of recognition assists us in a deeper analysis and a better understanding of the malaises of world politics and causes of

\footnotetext{
${ }^{365}$ Drawing of subjectivism, Nietzsche believes that power originates from our will; hence the will to power. In light of his interpretation, the will to power is the primitive form of affect, that all other affects are only developments of it. That is the willingness to employ or exercise power. I take an opposite way to argue that power means unwillingness - and ability - to not recognize different others. See: Friedrich Wilhelm Nietzsche, The Will to Power, Walter Arnold Kaufmann trans. and ed. (New York: Random House, 1967), pp. 366-381.

${ }^{366}$ James G. Hershberg, "The Cold War in Asia," Cold War International History Project Bulletin, issue 6\&7 (Winter 1995-96), p. 211.

${ }^{367}$ Francis Fukuyama, The End of History and the Last Man (New York: Maxwell Macmillan In ternational, 1992).
} 
conflicts, more particularly resistance against the Western vision of International Relations. ${ }^{368}$

Recognition as a basis for justice is the second area of investigation, which must be explored. This recognition-based approach to justice informs the field of International Relations and especially challenges the dominant conception of international justice, which refers to the relationship of actors in the international community of states, and more particularly to the discourse and practice of international law. In international justice, as Chris Brown argues, the reference point is neither the categorical account of the equal treating of states nor taking humanity as a whole into account. Nor does it refer to people who share our planet. It does not take for granted that the interests of those people are best served by the normative principles that underlie existing inter-state relations. Rather, this account of justice, which is concerned with the question of how to do justice to those who - due to their distinct identities - have been conceived as others and consequently have been excluded from the modern discourse of international life. ${ }^{369}$ This approach to justice demands the re-arrangement of the unjust structures and offers a

\footnotetext{
368 The literature of International Relations is replete with dissatisfaction towards the Western vision of this field. Of the most important voices of dissent, we can refer to a variety of critical theories ranging from Critical Theory to post-structuralism and critical social theory. In addition to these dissatisfactions which are mainly concerned with the issue of the 'otherness', the recent years have witnessed growing claims on a more recent mode of differentiation. Drawing on cultural identity this satisfaction with the Western discourse of International Relations is better highlighted. The current challenge between Iran and the US and its European allies is a clear example of the recent uprising against the Western vision of international relations. Even within the Western camp, the evidence of the resistance and uprising against the West is apparent. See for example Samuel Huntington's Clash of Civilizations highlighting the fault lines between the West and dissident voices. To follow this debate see, for example, Chris Brown, "Cultural Diversity and International Political Theory: From the Requirement to 'Mutual Respect"? Review of International Studies 26 (2000): 199-213. Also see Richard Falk, Human Rights Horizons, The Pursuit of Justice in a Globalizing World (London; Routledge, 2000), chapter 8.

${ }^{369}$ The following (mostly post-structuralist) sources are inspiring for the idea of otherness in the study of International Relations. Tzvetan Todorov, The Conquest of America: The Question of the Other (New York: Harper Perennial, 1982); and Peter Hume, Colonial Encounters: European and the Native Caribbean, 14921797 (London: Methuen, 1986).
} 
historically informed and interpretive perspective about what is to be taken as the point of struggle by the excluded states for recognition of their particular identity.

The re-adjustment of the unjust world order entails the questions of how this adjustment is done, who might do that, and more particularly who should recognize whom. This is a challenging question. I will argue that theory of recognition should be extended beyond the state-based discourse and practice of international law. It must also go beyond the formal acknowledgement of the recognition of legal equality, specified in the Charter of the United Nations. It should definitely shift away from the narrow representation of identity in the current world system toward a political and institutional account of recognition that is built upon the distinctiveness of states and the way through which they might contribute to the process of re-adjustment. ${ }^{370}$ The argument to be advanced at this point is that the re-adjustment is to be done within the context of global governance. Re-adjustment would be possible through the help of the organizations of national civil society, on the one hand, and global civil society, on the other. However, since in a globalizing world, powerful states depend on legitimacy, the pressures of civil society from inside and global civil society from outside turns generosity into a reciprocal account of mutual recognition and opens up new terrain for institutional recognition.

The third area of theorizing of International Relations, informed by recognition, is that recognition facilitates re-adjustment of world order and gives way to a more reliable

\footnotetext{
${ }^{370}$ In advancement of this idea, I have been inspired by Taylor's critique of the narrowness of rational procedures representation of identity. For details of this account see: Charles Taylor, "Lichtung or Lebensform: Parallels between Heidegger and Wittgenstein," in Philosophical Arguments (Cambridge: Harvard University Press, 1995). In addition, Taylor's approach to justice that encounters a variety of ethnopolitical, cultural, and even epistemological considerations involved in self-consciousness and selfenactment of formation of identity has been helpful in developing my account of world re-adjustment. See: Nick Smith, "Charles Taylor, Strong Hermeneutics and the Politics of Difference," Radical Philosophy 8 (Autumn 1994).
} 
solidarity. In this third line of argument in the present chapter, I draw on the conception of "overlapping consensuses" as a way to surmount the incommensurability of contestable perspectives of different nations leading to an achievement of a shared understanding of justice and communal values. However, "overlapping consensuses" which is advanced here is not to be interpreted in terms of "political compromise" achieved by mere negotiations among unequal parties without any account of substantial participation in global governance. Instead, it goes into deeper layers to appreciate the "fusion of horizons" in Gadamerian language. The political/ethical weight of the "fusion of horizons" empowers the alternative ways for substantial participation in global governance in order to not only overcome the incommensurability of contestable perspectives, but also to promote more inclusive and more just policies. Having been advanced by multiple channels of dialogue to promote shared knowledge and experience of political life, the "fusion of horizons" discloses the qualification of the life-world in a more all-embracing form of world order. ${ }^{371}$ This order would be a social construct because it has been created through a degree of substantial participation within the context of overlapping consensus. ${ }^{372}$ Recognition then becomes fertile terrain for mutual understanding, and thereby a channel of harmonization of contested values and solidarity. In what follows these three themes will be discussed in further detail.

\section{Dilemma of Non-Recognition and Power}

\footnotetext{
${ }^{371}$ In addition to Taylor, this idea is also advanced by Shapcott. See Richard Shapcott, "Cosmopolitan Conversations: Justice Dialogue and the Cosmopolitan Project," pp. 233-34.

372 I have taken this constructivist lead from Kant, who in the Groundwork of the Metaphysics of Morals, in the section on definition of categorical imperative, suggests that the natural order to be replaced by a 'universal law of nature'; a kind of social law has been produced by the universal imperative of duty. See Immanuel Kant, Groundwork of the Metaphysics of Morals, third edition, James W. Ellingtoned. (Indianapolis: Hackett Publishing Company, Inc., 1993), Para. 4:421.
} 
It is important to consider how different states - especially non-Western states must be politically and institutionally recognized by the rest of the world in order to fully participate in the life-world. The concern about non-recognition of different others has resulted in a globally spreading scepticism that considers the West - especially the US - as an oppressor crushing (democratic) different others such as the rule of democratic government of Iran in 1953 by non-democratic means ${ }^{373}$. Out of such growing consciousness, questions about the domination/subordination or sovereignty/obedience ${ }^{374}$ nature of the life-world are rising in today`s political landscape by asking "who is ruling over the world" and "are we being truly recognized as equal different beings". This spreading scepticism reflects a claim: "We are being ill treated by the West, or that our development is being frustrated by the West". ${ }^{375}$ This is not a polemical statement, but, rather, is a challenging claim grounded in deep philosophical reflections in the understanding of the undergoing shifts in the existing nature of the lifeworld and the willingness to change it. That is to say in the world today there is a will to change. Therefore, there should be an imperative to analyze and understand the will for change.

This kind of critical reflection seeks to advance the necessity of a certain substantive reform in the life-world's spirit and a system aiming to open the gate of dialogue, mutual recognition and understanding for the sake of a more reliable

\footnotetext{
${ }^{373}$ The democratic government of Mohammad Mosaddeq was overthrown by a coupe d'état by the US in 1953 Overthrowing the government of the Arbenz government in Guatemala in 1954 and efforts to destabilize the government of Allende in Chile in 1970-73 are other examples of American unwillingness to recognize different others.

${ }^{374}$ Taylor, "Foucault on Freedom and Truth," p. 158.

${ }^{375}$ Hartmut Rosa and Art Laitinen, "On Identity, Alienation and the Consequence of September 11 $11^{\text {th. An }}$ Interview with Charles Taylor," in Perspectives on Philosophy of Charles Taylor, Arto Laitinen and Nicholas Smith ed. (Helsinki: The Philosophical Society of Finland, 2002), p. 167.
} 
permanent peaceful life-world. Imperative to this reflection is the need to strive for institutional reforms to attain a more just world order that effectively addresses democratic values, participatory parity, transparency and accountability. However, such striving would be tenable when a more inclusive participatory policy in accordance with reciprocal political recognition is advanced and performed in the context of global governance. In spite of all these pressing demands for substantive reforms, since there is no central authority in the international system with the duty or possessing the power to advance and establish the central importance of recognition for a just life-world and order, this is the duty of all democratic states as well as the institutions of civil society (either domestically or globally such as Amnesty International and World Federalist Movement) ${ }^{376}$ to work towards opening the gate of dialogue and recognition in world society. These institutions such as "World Public Forum on Dialogue of Civilizations" search for a new humanism and a human-centric future. 377 "Institute for Global Ethics" defines its mission as exploring the idea of shared moral values and aspires to put them into practice. ${ }^{378}$ Montreal based Centre for Research on Globalization focuses on unspoken truth in world politics. ${ }^{379}$ The London based "One World Action" aims at a world free from oppression, where strong democracies safeguard people's rights. ${ }^{380}$ And recently emerging grassroots "Green Movement in Iran"381 for instance, have the

\footnotetext{
${ }^{376}$ As Institute for Global Policy one of the most umportant goals of the World federalist Movement is the creation of democratic global structures accountable to the citizens of the world and call for the division of international authority among separate agencies

${ }^{377}$ See World Public Forum on Dialogue of Civilizations at: http //www wpfdc org/

${ }^{378}$ See Institute for Global Ethics at hitp //www globalethics org

${ }^{379} \mathrm{See}$ Center for research on Globalization (CRG) at http //www globalresearch ca/

${ }^{380}$ See One World Action at http //www oneworldaction org/

${ }^{381}$ Mehd1 Khalaj1, "Who's Really Running Iran's Green Movement," Foretgn Poltcy, November $18^{\text {th }}, 2009$ Also see Iran's Green Movement at http /globalvoicesonline org
} 
potentials to pressures states to proceed dialogue for institutional change in the lifeworld.

But, the fact remains that established and practicing regime of recognition does not reflect the substantively political and institutional recognition of equality. ${ }^{382}$ For the state, indeed, to be fully recognized as equal is to be respected in their cultural differences. This implies that acknowledging culturally distinct others must be socially esteemed for its own sake, and that such recognition is imperative for cultural survival, and in the flourishing of their particular form of life. ${ }^{383}$ Therefore, an unwillingness to recognize different others or the politicization of the conception of recognition by more powerful states has undermined the spirit of a rules-based system of recognition which has been specified in many international documents among them the Charter of the United Nations. ${ }^{384}$ Many examples show how greater powers politicize the issue of recognition to justify their foreign policy objectives regardless of the rights of others to freely exercise their own sovereign will. ${ }^{385}$ Unwillingness of powerful states to not properly recognize the equal sovereign rights of different others (non-allied/enemies), I would claim, must be considered as one of the most significant tragedies of the modern history of international relations. More particularly, such unwillingness has always resulted in expansionist foreign policy orientations and the exercising of systematic

\footnotetext{
382 Article 1-2 of the Draft Declaration on Rights and Duties of States specifies the equal sovereignty of states. See Report of the International Law Commission on the Work of its First Session in 1949.

${ }^{383}$ See: Taylor, "The Politics of Recognition," p. 246.

${ }^{384}$ See Article 2(1) of the Charter of the United Nations, also the Declaration on Principles of International Law Concerning Friendly Relations and Co-operation among States in Accordance with the Charter of the United Nations, GA Res. 2625 (XXV), 1971.

385 Beyond the examples of politicization in the Security Council of the United Nations, IMF, and the World Bank, a clear example of politicization is the South African case to buy pharmaceutical products from Brazil and Clinton's administration objection to this case by drawing on patent rights protected by the World Trade Organization. See for example: Debora Jean Halbert, Resisting Intellectual Property (New York: Routledge, 2005), pp. 78-111.
} 
oppression $^{386}$ or in tragic events such as genocidal conflicts of 1990s in Rwanda and Burundi as well as Zaire. Unwillingness of the US and France to intervene in this region to prevent genocide reflects the most tragic dimension of recognition/nonrecognition dilemma in recent times. Accordingly, as especially as it can be read from the literature of post-colonialism, it can truly be argued that struggle for recognition has become one of the important sources of satisfaction and fulfillment of nationhood especially in nonwestern countries.

Undoubtedly, the recognition/non-recognition dilemma lends credibility to the realist, more particularly the so-called "offensive realist", face of power-seeking in an insecure model of world order and resistance against it. The self-helping dimension of realism, where hierarchies are established among different political and legal units, apparently discloses the question of why political recognition of equality of different others has be denied. ${ }^{387}$ Within this perspective, states are left - to differing degrees - in a dilemma of either trying to expand their hegemony over different others or become submitted to the political will of others. "Other is always a threat to my own experiences of self, having the power to objectify me and to cause me to flee into selfobjectification". ${ }^{388}$ This dilemma implies a disposition of the stronger party to undermine the political will of different others as equal players in order to exploitatively control

\footnotetext{
${ }^{386}$ For equalization of unwillingness to recognize with expansion ist policies with an stress on British imperialism see: Lou is, William Roger, Ends of British Imperialism: the Scramble for Empire, Suez and Decolonization: Collected Essays (London: I.B. Tauris, 2006), especially chapter 33 on "The scramble for Africa : Sir Percy Anderson's grand strategy," pp. 51-74.

${ }^{387}$ The following source is interesting for reading on the relationship of the hierarchical order of the world, devaluation of equal sovereignty and the existence of inequality. Benedict Kingsbury, "Sovereignty and Inequality," in Inequality, Globalization, and World Politics, Andrew Hurrell and Ngaire Woods ed. (Oxford ; New York : Oxford University Press, 1999), pp. 66-94.

${ }^{388} \mathrm{I}$ borrowed this strong verdict from Sartre to emphasis the dilemma of recognition/non-recognition. See: Sonia Kurks, "Fanon, Sartre, and Identity Politics," in Fanon: A Critical Reader, Levis R. Gordon, T. Denean Sharpley- Whitibg, and Renée T. White ed. (Oxford: Cambridge, Mass.: Blackwell Publishers, c1996 Oxford: Cambridge, Mass.: Blackwell Publishers, 1996), p. 124.
} 
(oppress) them. Also, it entails a struggle latent in the subordinated condition of the controlled or oppressed party to be recognized as autonomous and independently different. For this reason, I argue that the cause(s) of conflicts and recurrent patterns of aggressiveness are to be found neither in the power-seeking characteristics of states nor in the anarchical system, but in the very tragic logic of the non-recognition-recognition struggle. This ceaseless struggle marks the nature of and becomes the proper manner in understanding the behaviour of actors in international politics in its historical context.

Whatever impulse lies beneath the unwillingness, both the politics of "others as enemy" and the politics of "generalized others", fail to acknowledge the substantive contribution of different others in the life-world in political discourse, especially those who are basically labelled as non-Westerners. ${ }^{389}$ This failure, which causes harm and repression, motivates normative and philosophical reflection with respect to the logic behind the justification of "others as enemy" and "generalized others". It is in light of this substantive and normative reference to the concrete content of repression that the importance of recognition is uncovered.

However, the tragic unwillingness to recognize different others can hardly continue. The fact is that process of globalization, such as the growth of forces beyond the control of states, questions the more powerful states' unwillingness to recognize different others, especially the emergence of transnational civil society - from the International Chamber of Commerce to Catholic Church and advocacy groups such as women movements. It addition, the shift in political, economic, technological, demographic, and even military power the North to the Global south driven by rise of India and Brazil, for

\footnotetext{
${ }^{389}$ Stuart Hall, "The West and the Rest: Discourse and Power", in Formations of Modernity: Understanding Modern Societies, Stuart Hall and Bram Gieben ed. (Cambridge: Polity Press/Open University, 1992), p. 289.
} 
example, and the mounting influence of regional and sub-regional organizations have seriously challenged the position of more powerful states. Therefore, the stronger states are losing their strict control over the process of planning and operating world affairs. They are facing not only serious "peer competitors" - Japan and China, for instance - but also emerging transnational threats - such as international terrorism, pandemic infectious disease, climate change, and drug cartel - with capabilities of inflicting enormous harm. In addition, the institutional changes in the political order of the world and the multiple channels of action-interaction and communication question the dominant language of power. ${ }^{390}$ Therefore, there is an urgency to discuss the importance of dialogue and mutual recognition within the re-adjusting of the ongoing turbulent lifeworld, because, as Taylor argues, "the struggle for recognition can only find one satisfactory solution, and that is a regime of reciprocal recognition among equals". ${ }^{391}$ This ideal of reciprocal recognition of the other's status, as both different and like oneself, demands that participants in the life-world extend to each other the acknowledgment that they have different background developments to their nationhood, and that such difference could work as complement.

Accordingly, we can see a mutually enforcing relationship between misrecognition as oppression and mechanism and application of invisible power. Indeed, power has always been practiced by setting different others as strangers, non-allied, and enemies as well as by unwillingness to recognize them like oneself. It is obvious that power in this

\footnotetext{
${ }^{390}$ Although not a new work, the following is a rich analysis of the transformational change in the language of power in world politics: Robert Owen Keohane, "Hobbes's Dilemma and Institutional Change in World Politics: Sovereignty in International Society," in Power and Governance in a Partially Globalized World (London; New York: Routledge, 2002), pp. 63-87.

391 Taylor, “The Politics of Recognition," p. 50.
} 
sense does not connote the ability to enforce others in a certain direction on a purely topdown basis, like the Hobbesian "sovereignty/obedience" model with judicial and forceful means for subordinating others. It is not also an altogether decentralized and ubiquitous phenomenon proceeding through a vast network of institutions, professions, and practices within a larger organization. Nor, again, is it even the logic behind the disciplinary societies of modern time ${ }^{392}$. It is rather something that imposes constraints on the will of agency; either individuals or nations determine who they are. It is antithetical to self-interpretation and self-realization and, by which, a hostile adversary to authenticity and freedom. Power must be resisted, because it renounces the very idea of freedom. If power is not interpreted as the exclusive hostility to freedom of the will, it will dangerously be misconceived. It does not make sense without having the conception of freedom as its exclusive target. ${ }^{393}$ In the absence of freedom when interpreting power, the nature and exercise of power remains deceptively unexplored.

Accordingly, the omnipresent deceptive face of power would be misconceived and misleading if we do not take human agents as its subject. Within his perspective, indeed, power must be counted as the other face of domination but in a different way from the old style of domination by forceful means. In other words, in order to be dominant, the stronger misrecognize and even deny the agency of different others. Such misrecognition serves as a means of domination and power application. That is to argue that domination resides within the context of non-recognition. Misrecognition and non-recognition are the means of domination, hence oppression. Grafting this interpretation of power to the

\footnotetext{
${ }^{392}$ Michel Foucault inspires these reading of power. See: Michael Foucault, Power/Knowledge: Selected Interviews and Other Writings 1972-1977, Colin Gordon ed. (New York: Pantheon Books, 1972); and Michael Foucault, "The Subject and Power," Critical Inquiry 8, no. 4 (Summer 1982): 777-795.

${ }^{393}$ Taylor, "Foucault on Freedom and Truth," p. 173.
} 
theorizing of International Relations, the thesis can be advanced that the conscious unwillingness to recognize different others involves their direct annihilation as well as their effective self-determination. In a wider scale, such unwillingness involves the negation of a nations' conceiving of themselves as free and self-defining entities in accordance with their own background of difference and unique culture.

Indeed, there is a direct link between agency and freedom, and effective selfdetermination. Our identity - individual, group, or nation - would be at risk if we were not effectively self-determining agents. Such effectiveness is the necessary condition of true self-determination and freedom as the characteristics of human agency. The figure bellow shows the nonrecognition/misrecognition obstacles against the effective selfdetermination of states.

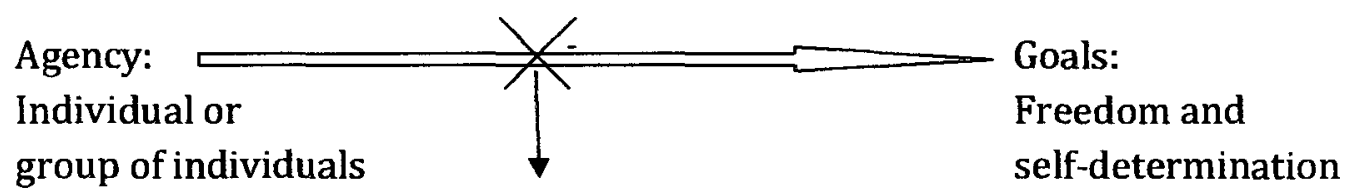

Not allowed Misrecognition

If effective self-determination is the a priori condition for agency, it must also be the necessary condition for being a responsible agent. It means that, due to this very freedom and self-determination, the agent must be a reflective self-evaluator, responsible for his actions as well as being reciprocally sensitive to what others do. ${ }^{394}$ Having this argument in mind, I maintain that the unwillingness to recognize different others must be considered the main cause of oppression and injustice, and must consequently be resisted. By virtue of this argument, recognition of others informs the ethics of liberation.

\footnotetext{
${ }^{394}$ See: Charles Taylor, "What is Human Agency," in Human Agency and Language (Cambridge: Cambridge University Press, 1985), pp. 15-44.
} 
We now arrive at the conclusion that misrecognition affects negatively the freedom of agency and effective self-determination, and facilitates the application of power. That is to say it targets effective self-determination as truth of identity and prevents the expressivist portrait of oneself and their sense of who (s)he is. This insight provokes an understanding of power as a threat to effective self-realization and determination. Since self-determination has been specified as a universal right, unwillingness to recognize this right poses a threat to the will of the nations. In other words, the novelty of this approach to power lies in the equation of non-recognition as the prevention of effective self-determination. In this sense, self-determination means a nation's ability to construct deliberately the essence of its nationhood. This ability depends on the internalized exercise of freedom. Power as non-recognition negates this account of freedom and effective self-determination.

Accordingly, willingness to recognize others different from oneself must be considered as the thrust of any plan for a re-adjustment of the world. Indeed, willingness to move from misrecognition to recognition is the key in the reformulation of the just lifeworld. That is to confirm and willfully acknowledge the equal worth of all different others regardless of their differences, as long as the culture of accountability is respected and exercised. ${ }^{395}$ Accountability and the recognition not only serves as the criteria in the ethics of liberation, but also further encourage openness for dialogue and mutual recognition as the true means of justice.

\section{Recognition as Justice}

\footnotetext{
395 I set the culture of accountability versus the culture of impunity to define the true foundation for the exercise of freedom as being a just world order. Accountability in this sense is a challenge to any despotic account of sovereignty.
} 
The urgency of a move away from unwillingness toward willingness in recognizing different others is indeed a call for a more inclusive world order. This account of recognition provides a reflective basis for a conception of social justice that transcends the current conception of international justice. Justice in the latter sense refers to the normative principles that underline the relationship between states "as encapsulated in the practice of international society, most particularly the discourse of international law". ${ }^{396}$ In other words, international justice addresses the rights and duties of states and international organizations and corporations to one another. This approach to justice has been developed based upon an acceptance of existing world order in which more powerful states - through consensus among themselves - determine who should be recognized as the privileged player in the life-world ${ }^{397}$ In this normative framework, the conventional legal recognition is the norm and disadvantaged different others are to follow this already established norm of international justice. Truth be told, in this sense, domination/ subordination - particularly an economic sovereignty/obedience - model of world order lacking any emancipatory promise for excluded others are represented as justice. In this perspective, different others - Afghanistan for instance - are supposed to obey the discourse of international justice in order to enjoy the altruistic attitude stemming from the moral arbitrariness of richer toward poorer people and/or the charitable sort of transferring recourses and wealth from the North for the South. John Isbester in his inspiring work, Promises not Kept, gives a thoughtful analysis of such obedience by looking at different theories of development prescribed by the North to the

\footnotetext{
396 Brown, "From International to Global Justice," p. 261.

${ }^{397}$ To have a full account of international justice and its variations see: Allen Buchanan, Justice, Legitimacy, and Self-Determination: Moral Foundations for International Law (Oxford: Oxford University Press, 2004).
} 
South ${ }^{398} \mathrm{He}$ believes that the poverty and the betrayal of the Third World development stems from the very sovereign/obedience nature of world order.

Upon taking a closer look into the moral arbitrariness and the resulting altruistic duty reveals the fact that a liberal theory of justice only reminds liberal people of their imperfect duty to assist those who are suffering from a maldistribution of primary goods. ${ }^{399}$ Due to the fact that they are corporate moral agents, liberal peoples have this kind of "imperfect duty" to broaden the boundaries of their affluent society to the global level and assist peoples who are under severe economic inequality and impoverishment. This imperfect duty must be directed toward even non-liberal peoples. ${ }^{400}$ This moral arbitrariness originates from the capacity of liberal people to have a conception of the good life expressed in accordance with a sense of justice. Viewing justice as a matter of fairness, O'Neill also endorses a constructivist interpretation of the idea of 'imperfect duty" and places it at the centre of a moral system. ${ }^{401}$ Therefore, the imperfect duty of liberal peoples (nations) assists in surmounting existing inequality for the sake of a purposeful, just conception of a good life-world.

However, the liberal perspective of justice does not address the causes of the ongoing unjust oppressive world system. Nor does it offer any clear account of dialogue

\footnotetext{
${ }^{398}$ John Isbister, Promises not Kept: Poverty and the Betrayal of Third World Development (Bloomfield: Kumarian Press inc., 2006).

${ }^{399}$ Although being committed to 'negative duties', Thomas Pogge tends to extend beyond claiming that whether or not we accept such a duty towards global justice, we make a momentous moral difference. Pogge, World Poverty and Human Rights, p. 133. In his later, Pogge favors a path through which the controversy over 'negative/positive duty' is overcome. See Thomas Pogge, "The International Significance of Human Rights," The Journal of Ethics 4 (2000):45-69.

${ }^{400}$ Peter Singer is among those of ethicists who have long appealed to the moral responsibility of peoples of affluent countries to assist with the poorer people in the world. See: Peter Singer, "Famine, Affluence, and Morality," Philosophy and Public Affairs 1 (1972): 229-43. For similar accounts see: Amartya Sen, Poverty and Famine (Oxford: Clarendon Press 1981).

${ }^{401}$ Onora O'Neill, Towards Justice and Virtue: A Constructive Account of Practical Reasoning (Cambridge:

Cambridge University Press, 1996), pp. 127.
} 
and mutual recognition to genuinely cure the problem of non-recognition as oppression. In fact, under the normative perspective of justice, which appreciates the current privileged (legal) recognition-based international system, and hence insists the imperfect duty, it does not make sense to give a voice to those who have been oppressed as a result of the practices of non-recognition ${ }^{402}$ In general, it could be firmly claimed that liberal insight par excellence - the ideal that all nations are formally equal - remains eminently empty of any meaning due to the fact that it never questions non-recognition as a means of the application of power. Hence, it cannot be an emancipatory insight. For these reasons, the liberal perspective of justice is prone to severe critiques launched either by critical theories or recognition-based approaches. More particularly, the latter approach not only looks at the root causes and diagnoses the evil of injustice, but also prescribes and promotes recognition as a solution for it.

Accordingly, recognition as justice highlights new features in the contemporary life-world. The first is that political recognition meets the requirements of the highly pluralistic contemporary globalizing world. Since recognition begins willfully, it reflects an acknowledgment that no justice is possible without recognition of different others as oneself. The imperative behind this acknowledgment generates an emancipatory discourse envisioning a "rooted cosmopolitan" world. That is to assume that recognition as justice brings about a new direction into the world in which the relationship between identity and change, unity and plurality, and politics and agency is accommodated. As a

\footnotetext{
402 In order to analyze the inability of normative theory see: Debra Satz, "International Economic Justice," in The Oxford Handbook of Political Ethics, Hugh LaFollette ed. (Oxford: Oxford University Press, 2004, pp. 63637. For a detail analysis of hegemony and power domination see Howard H. Lentner, "Hegemony and Autonomy," Political Studies 35 (2005): 735-52; and Ray Kiely, "United States Hegemony and Globalization: What Role for Theories of Imperialism?" Cambridge Review of International Affairs 19, no. 2 (June 2006): 205-21.
} 
result, the conflictual visions are turned into dialogue and mutual recognition. ${ }^{403}$ Recognition as justice then requires openness and global dialogue over the politics of inclusion and effective participation with minimum cultural, rational, geographical, and national restrictions.

The second feature is the distinct implications of this articulation of justice for the dynamism of exclusion and oppression. Recognition of different others as the necessary condition of justice is an alternative way and a response to the failure of the conception of justice. The latter approach to justice has been developed in accordance with the universal principle of equality without discrimination and appreciates the importance of the equality of difference. Indeed, while at the dawn of modern times, difference was a problem in response to which equality was a solution, in the contemporary world the idea of sameness is one of the major problems to which the appreciation of difference is the solution. ${ }^{404}$

The third is the importance of recognition as justice in uncovering the dark side of modern international relations. A glance at recent history from $18^{\text {th }}$ century onward reveals the fact that international politics has been constructed by multiple patterns of exclusion and oppression. It is not plausible then to turn a blind eye toward these grave sources of misery of many nations and leave the historically contingent unjust system unquestioned. In this respect, as it was argued earlier in this chapter, non-recognition

\footnotetext{
${ }^{403}$ Having a Hegelian origin, the term 'rooted cosmopolitan ism' allows the intensity of globalization to be limited due to the active presence of autonomous communities. In the 'rooted cosmopolitan' perspective rational ethical principles gradually spread around because of the fact that states become less antagonistic to the ethics of recognition. Through recognition, autonomous rational actors become more responsible for communal life as a result of which a more just international order is formed that addresses the requirements of the globalizing era. For a detail similar idea see Omar Dahbour, "Three models of Global Community," Current Debates in Global Justice, pp. 201-24.

${ }^{404}$ Simon Thomson, "Is Redistribution a Form of Recognition? Comments on the Fraser-Honneth Debate," Critical Review of International Social and Political Philosophy 8, no. 1 (March 2005): 86
} 
must be regarded as the cardinal cause of exclusion and oppression. Non-recognition has always paved the way for application of direct power. ${ }^{405}$ That is why I argue that political recognition is an a priori condition for the restoration of the oppressed voices and the readjustment of the world order.

The fourth feature of recognition as justice, it must be argued, is the importance of effective self-determination for an re-articulation and re-definition of the life-world. This approach to justice appeals the true respect for and appreciation of the equal worth and values of different others and considers it as a precondition for just relations in the lifeworld. In other words, willingness to acknowledge the effective self-determination of others helps remove the guilt of non-recognition as the means of exclusion and oppression. Since effective self-determination restores true self-confidence, it stands qualitatively above all other attempts for emancipation of the excluded others. Recognition for the sake of self-confidence helps also recover a sense of agency and consequently inspires active participation in the re-articulation of an all-inclusive lifeworld.

\section{Civil Society Helping Recognition as Justice}

Having discussed the theoretical advantages of recognition as justice, one of the research questions has still remained unanalyzed and unanswered: Who should recognize whom, and how? This question ushers my account of recognition as justice into a new phase. In an effort to respond to the question I begin with the argument that those who influence the process of planning and managing of global governance are responsible to

\footnotetext{
405 Jacinda Swanson, "Recognition and Redistribution, Rethinking Cultural and the Economic," Theory, Culture, and Society 22, no. 4 (2005): 100-101.
} 
ensure that world order satisfies the requirements of justice through recognition. Such responsibility derives from the categorical duty to acknowledge equal worth of different others and consequently necessitates openness for substantial dialogue over an allencompassing participatory model, rather than mere conventional negotiations and bargaining over satisfaction of benefits of those who are in a higher position. Kofi Annan, the Secretary General of the UN at the time, for example, in his agenda for the UN Millennium Program called for coalition building among nations, NGOs, and private sectors in order to remove the causes of many global malaises, among them the problem of poverty. His agenda reflects the necessity of a dialogue aimed at reducing global issues beyond the scope of traditional assumptions of international relations. ${ }^{406}$

Although quite interesting in its language, however, these measures must also be accompanied by the struggle of the excluded others against the patterns of discrimination and oppression so that they may become true participants in of the life-world and its planning and managing institutions in all universal, regional or sub-regional, and national levels. Building on these areas of global governance, struggle for recognition must also consider the potentials for reform in the major institutions of global governance (e.g., the UN and IMF) to advance feasibility of the manners of negotiation, collaboration, and participations. Such reforms help decrease both the severity of power and thriftiness of collaboration for mere interests of the more powerful states and simultaneously increases the self-confidence of different others in their struggle for recognition. Furthermore, it is a constructive model, expressing an inspiration to fill in the gap between the stronger and

\footnotetext{
${ }^{406}$ See: Kofi A. Annan, We the Peoples: The Role of the United Nations in the $21^{\text {st }}$ Century (New York: United Nations Department of Public Information, 2000).
} 
weaker, and a promising voice for a more just world in which a more democratic and transparent pattern of political and institutional order is achieved.407

The importance of recognition as justice has been acknowledged in a number of legal instruments with varying degrees so far. There are universally accepted documents as well as world-wide efforts made to justify the urgency of transformations in global governance in favour of recognition as justice. The most important of those documents are the Charter of the United Nations and the Universal Declaration of Human Rights. Article 2 (1) of the Charter, for example, specifies the firm duty of the members of the UN to respect the sovereign equality of all its members, and article 28 of the Universal Declaration also stipulates that "Everyone is entitled to a social and international order in which the rights and freedoms set forth in this Declaration can be fully realized". ${ }^{408}$ Although the language used in these two documents implies two different purposes, the logic behind both documents spells out a categorical claim on the universality of equal worth of all members be they states (the Charter) or individuals (the Universal Declaration). This claim confirms recognition to be considered as an a priori condition for a just, and by implication a peaceful life-world. Since the gravity of both documents falls into the legal recognition of equality without stipulation of any differences, i.e. being individual or nation, such equality must also be politically acknowledged in order to give justice to the relationship between all different individuals and/or states. Recognition of different but peace-loving, right-respecting, and justice-advocating states at the level of

\footnotetext{
407 Richard A. Falk, "The Making of Global Citizenship," in Global Visions: Beyond the New World Order, Jeremy Brecher, John B. Childs, and Jill Cutler ed. (Boston: South End Press, 1993).

${ }^{408}$ Documents endorsing the necessity of dialogue and mutual recognition also include, among others: The UNGA Resolution A/RES/56/6, Global Agenda for Dialogue among Civilization, 2001specifying in Article 3 "Commitment to inclusion, cooperation and the search for understanding as the mechanisms for the promotion of common values".
} 
global governance not only transforms the institutional structures and world order, but also supports an unforced world consensus about who should be recognized and why. ${ }^{409}$

There are also practical plans promoted at the international level to implement recognition as a prerequisite of a just global governance and order. For example, in order to match the requirements of being an individual with the requisites of being a legitimate state, some thinkers such as Mary Kaldor, David Held, and Richard Falk have favoured a positive discourse of sovereignty and responsibility of states expressing maintenance of human rights and standards of democratic rule. ${ }^{410}$ States are legitimate as long as they are responsible in a socially constructed and universally agreed upon network of norms, values and beliefs. For example, states which are holding legitimate authority linked with the universal norms of human rights and democratic values within the EU framework, are legitimate states due to the fact that they represent the will of their nations. However, democratic states must accept the responsibility to promote human rights norms and democratic values in international stage as well. ${ }^{411}$ That is to say, states who take their legitimacy from democratic rules - be they internal or external - should take measures to recognize other states and also promote human rights. This responsibility requires all states to respect the rights of other states in articulating their own mode of life and to stay in constructive dialogue on matters of controversies. Aimed at complementing the

\footnotetext{
${ }^{409}$ To further elaborate the Taylorian inspiration for this claim see Charles Taylor, "A World Consensus on Human Rights," Dissent (Summer 1996): 15-21.

${ }^{410}$ Mary Kaldor, Human Security: Reflections on Globalization and Intervention (Cambridge, UK: Polity Press, 2007), pp. 77-83; and David Held, "the Changing Structure of International Law: Sovereignty Transformed?" in The Global Transformations Reader: An Introduction to Globalization Debate (Cambridge, UK: Polity Press, 2000), pp. 162-176. Richard Falk, Human Rights Horizons: The Pursuit of Justice in a Globalizing World (London: Routledge, 2000) and Richard Falk ed., International Law and the Third World: Reshaping Justice (Abingdon: Oxon: Routledge-Cavendish, 2008).

${ }^{411}$ There are evidences of disregarding this responsibility by more powerful states as we can see in the case of Iran's democratic government of Mohammad Mosaddegh, which was overthrew by an American-led coup d'état in 1953, or even pressures of the US on democratic government of Mohammad Khatami.
} 
Universal Declaration of Human Rights, the Universal Declaration of Human Responsibility clearly specifies such a responsibility as the basis for global ethics. A number of philosophers, such as Hans Kung and Richard Rorty, in 1997 in UNESCO's headquarters in Paris, aspired to establish a regime of responsibility of states that promotes responsibility to recognize and protect everyone without any reservations ${ }^{412}$. Although this dream never came true, but the path for reflection on a more feasible and practical alternative initiative has still remained open.

In spite of all hopes and efforts for the promotion of more inclusive policies to attain a just world order, the untrammelled power of more powerful states to maintain self-interest pattern of politics has still remained the predominant attitude in international relations. Therefore, in order to explore the causes of the unsuccessfulness of establishing a regime of responsibility for the advancement of dialogue and mutual recognition, one needs to look at the contradiction between the unrestricted application of power and promises of civil society. There is a good example to see how in spite of the evident oppression and the brutal violation of human rights of Iranian peoples, Barak Obama apparently approached a new diplomatic initiative to negotiate nuclear issue with the Islamic government of Iran, regardless of the grave violation of human rights especially in post-election Iran. ${ }^{413}$ But, there are signs of change in Obama's position toward Iran, after civil society in Iran and abroad accused Obama for not caring for

\footnotetext{
${ }^{412}$ See Universal Declaration of Human Responsibilities, proposed by the InterAction Council in 1997 (as amended in 1998) for consideration by the United Nations as a complement to the Universal Declaration of Human Rights at: www.asrawide.org.jp/iac/UHDR/EngDecii.htm. Also see: Mary Maxwell, "Toward A Moral System for World Society: A Reflection on Human Responsibility," Ethics and International Affairs 12, no. 1 (1998): 179-93.

${ }^{413}$ Kareem Shaheen, "Obama must Press Iran on Human Rights," The National, November 08, 2009.
} 
Iranian people. ${ }^{414}$ These examples reveal the fact that there is still a long confrontation between power politics and the realm of civil society.

However, information technology facilitates the spreading challenge of civil society against the authority of states around the globe. The former favours recognition and dialogue, while the latter is eager to articulate the interests of the more powerful states. While the former aims to search for the causes of fundamental political cleavages and makes efforts to promote democratization and social behaviour, the latter is still permeated with plans that are closely tied to the interests of the more powerful states. It scarcely requires further argument that in spite of the fact that a number of nation-states have turned to democracy, the relationship of the states is still managed and controlled undemocratically. ${ }^{415}$ In other words, while democracy at the national level exposes a promising improvement, international relations, and more particularly, global governance is suffering from the logic of self-interest calculation, intimidation, coercion, and even the application of force in its multi-faceted characteristics. In his agenda for democratization of the world order, Boutros Ghali, the former Secretary-General of the United Nations pointed to the undesirable obstacles - such as insurmountable cultural obstacles or the presence of military regimes - as standing on the way of the advancement of a democratic world order and tried to promote the norm of democratic global governance ${ }^{416}$. His attempts were aimed at promoting a more inclusive world order and global governance alongside the democratization of nation-states. He was especially

\footnotetext{
${ }^{414}$ See: http://www.huffingtonpost.com/david-elliott/as-obama-scores-an-iran-b_b_312940.html 415 See David Held, "Globalization, Cosmopolitanism, and Democracy: An Interview with David Held," Constellations 8, no. 4 (2001): 427-41.

${ }^{416}$ Simon Rushton, "The UN Secretary-General and Norm Entrepreneurship: Boutros Boutros-Ghali and Democracy Promotion," Global Governance: A Review of Multilateralism and International Organizations 14, issue 1 (January-March 2008): 95-110.
} 
interested in gaining the support of powerful states; an attempt which remained unsuccessful because of the unwillingness of the more powerful states for change.

Looking realistically at the current world order, there is an obvious unwillingness of the bigger powers to recognize different others as equal. This has paralyzed attempts at reform and the democratization of world order and global governance. Nevertheless, it is still possible to put pressure on the unwilling states through the organization of civil society in favour of fundamental reform and the acceptance of dialogue with others. Built upon a system of international pressures on the development of human rights, these organizations are able to press governments to change their policies and "fulfill - to a certain extent - the role of an international ombudsman for human rights". ${ }^{417}$ I argue that pressuring states would be through a dual-layer measure: firstly, by way of a bottom-up pressure by national civil society on their own states, and secondly, by way of a challenge from transnational civil society to decrease pressures towards politicization and increase the democratization of global governance. The latter, especially has the capacity of extending the scope of pressure on states by drawing on cross-cutting alternatives and global networks.

From within, the organization of civil society can facilitate the space for public participation and further extend the scope of the public sphere, resulting in pressures of democracy from below. As it can be seen in case of Iran today, the "green movement" for human rights and democracy is gradually spreading, and in spite of all oppressive means - police, paramilitary Islamic groups, mass media - in the hands of the Islamic regime, it is

\footnotetext{
417 Felix Ermacora, "Non-Governmental Organizations as Promoters of Human Rights," in Human Rights: The European Dimension, Franz Matscher and Herbert Petzold ed. (Koln: Karl Heymanns Verlag, 1988), p. 180, cited in William Korey, NGOs and the Universal Declaration of Human Rights: A Curious Grapevine (New York: St. Martin's Press, 1998), pp. 18-19.
} 
rapidly developing among citizens in towns and villages. Through dissemination of knowledge and deepening of public communication, the movement also demostrates the importance of tolerance, democratic spirit, civic virtues, and peace values and, hence contributes to the general transformation of public consciousness. In this stance, in general, governments - especially those of democratic ones - are pressured to act upon or change their policies and withdraw from oppressive perspectives.

From a global perspective, pressure can be mounted against states through articulation of radical forms of transnational mobilization and socialization. At this stance, pressure is completed by an emerging - although still weak - mode of governance which is open to multiple channels of participation and deliberation by global citizens across the boundaries. Often, transnational civil society stands on a day-to-day campaign for linking human rights and democratization to dialogue, mutual respect and recognition. This also happens through building a public sphere within the institutions of global governance, especially the United Nations for the de-politicization of the process of decision making aiming at more socialization and peace-building capacity. ${ }^{418}$ This takes place through attempts for transparency and democratization of the process of decision-making. Indeed, the high potential of civil societies to "act as a 'transmission belt' between deliberative processes within international organizations and emerging transnational public sphere"419 further smoothes the way of de-politicization within international organization.

\footnotetext{
${ }^{418}$ See: Robert A. Dahl, "Can International Organizations be Democratic: A Skeptic View," in Democracy's Edge, Ian Shapiro and Casiano Hacker-Cordón ed. (Cambridge: Cambridge University Press, 1999), pp. 19. 36.

${ }^{419}$ Patrizia Nanz and Jens Steffect, "Global Governance, Participation, and the Public Sphere," in Global Governance and Public Accountability, David Held and Mathias Koenig-Archibugi ed. (Malden: Blackwell Pub., 2005), p. 199.
} 
This kind of double pressure on states is becoming fashionable in the crafting of the structures of a new life-world and influencing on the nation-states as well as the global governance. ${ }^{420}$ The world-wide anti-war demonstration against the war in Iraq in 2003 is one example which shows the potentials latent in transnational civil society. This has been interpreted by some thinkers in terms of an emerging associational revolution versus power politics. However, the question is whether such a socially ideal revolution is compelling enough to influence the more powerful states to launch certain changes in global governance, leading to the recognition of different others and consequently their participatory parity in a more just world.

Developing this account of the social world versus the coerciveness of power politics is important for a recognition-based approach to justice because it entails not only academic significance, but also involves insights on the practical measures required to challenge the enforcing power and hegemony of powerful states. However, it is evident from the beginning that the term civil society, in its contemporary usage, refers to the social versus the political world or the resistance of people versus a compelling and undemocratic statism. Moving to a global level, in a globalizing world, transnational civil society reflects pressures from below versus pressures from-above. ${ }^{421}$ This definition and potential of transnational civil society removes the vagueness with the definition of civil society, and portrays a picture of the world in which the sovereignty of state is declining

\footnotetext{
${ }^{420}$ See: Daniel Robert DeChaine, Global Humanitarianism: NGOs and the Crafting of Community (Lanham, MD: Lexington Books, 2005).

${ }^{421}$ See: Sanjeev Khargram, james V. Ricker, and Kathryn Sikkink ed., Restructuring World Politics: Transnational Social Movements, Networks, and Norms (Minneapolis: University of Minnesota Press, 2002); Burgerman, Susan, Moral Victories: How Activists Provoke Multilateral Action (Ithaca: Cornell University Press, 2001.); and Richard A. Higgott, Geoffrey R.D. Underhill, and Andreas Bieler ed. Non-State Actors and Authority in the Global System (London; New York: Routledge, 2000).
} 
due to the challenge of social forces. ${ }^{422}$ Giddens argues that the contemporary usage of civil society is different from older definitions, because, unlike the old labour movements, it is not oriented toward the conquest of political power. Rather, it is concerned with the equalization of rights, participation, and then self-realization. It is concerned with a form of "life politics in which instrumental rationalization and commodification are resisted by social movements advocating autonomy" versus subordination to a state's power. ${ }^{423}$ Therefore, the term civil society is instrumental itself in challenging the state Leviathanism for the promotion of a goal-oriented democratization at both the state and inter-state levels.

In light of these observations, it is convincing to argue that civil society at both the national and global levels affects democratic and authoritarian regimes alike and provides fertile ground for a rooted model of cosmopolitan governance. More particularly, and for the purpose of this research, we can argue that civil society promotes the significance of an embedded public sphere, which operates as a ground for scattered sovereignty in a system of global governance. The root of cosmopolitan governance is the idea that democracy would be succeeding through a multilayered cosmopolitan model with appreciation of a sense of political community in different contexts. Therefore, one is convinced to argue that potentials latent in civil society not only undermine the statist and territorial character of international relations, but also enhance civil society as one of

\footnotetext{
${ }^{422}$ Richard Falk, "Resisting Globalization from Above through Globalization from Below," in Globalization and the Politics of Resistance, B. Gills ed. (London: Macmillan, 2000), p. 49. Similar ideas raised by: Thomas J. Biersteker, Cynthia Weber, State Sovere ignty as Social Construct (Cambridge: Cambridge University Press, 1996), pp. 14-15 and Katherine L. Lynch, The Forces of Economic Globalization: Challenges to the Regime of International Commercial Arbitration (The Hague; New York: Kluwer Law International, 2003), p p. 58-64. ${ }^{423}$ Anthony Giddens, The Consequence of Modernity (Cambridge: Polity Press, 1991), p. 214.
} 
the agents of democratic global governance ${ }^{424}$. But, it is an agent that operates from below for democratization of the world structure and order. Interestingly, in this account of civil society, great emphasis is placed on agency for a transformational path to the democratization of the life-world. Transnational civil society pressures the statism of global governance from below. The advocates of civil society then rightly appreciate the bottom-up or solidarist orientation of transnational civil society to achieve a global ethics, than the construction of a global polity. ${ }^{425}$ This achievement would promise certain emancipation of global governance from the control of states and makes them more responsible. ${ }^{426}$

Accordingly, there is a hope that the general invocations of human good will can also further enhance the success of social voices in assisting the enforcement of the political will of states for reform in world order. ${ }^{427}$ This line of reasoning, in favour of possible pressures on states for adopting more inclusive policies, has been confirmed in different ways. For example, on the 50th anniversary of the founding of the United Nations in 1995, a number of reports were presented on how to resist the unwillingness of bigger powers for reform in global governance, although no realistic solution has remained to reform the Security Council. ${ }^{428}$ There is also evidence that increasing consciousness stimulated by social movements and NGOs about the common fate of humanity and the emerging power shift has encouraged a number of statesmen,

\footnotetext{
${ }^{424}$ See Richard Falk, "The UN and Cosmopolitan Democracy," in Re-imagining Political Community, Daniele Archibugi, David Held, and Martin Kohler ed. (Cambridge: Polity Press, 1998) and David Held, Democracy and Global Order: from the Modern State to Cosmopolitan Governance (Cambridge: Polity Press, 1995). ${ }^{425}$ Baker Gideon, Civil Society and Democratic Theory, Alternative Voices (London and New York: Routledge, 2002), p. 120.

${ }^{426}$ Falk, "The UN and Cosmopolitan Democracy," p. 327.

${ }^{427}$ See Righter, R. Utopia Lost: The United Nations and World Order (New York, Twentieth Century Fund Press. 1995).

428 'UN Gets no Nearer to a New Security Council', internationai Herald Tribune, 30 September 1997.
} 
international organizations, diplomats, and bankers to be willing to dialogue with the institutions of civil society. ${ }^{429}$ The dialogue covers a variety of issues related to the lifeworld, such as human rights, women's rights as human rights, environmentalism, disarmament, but more importantly struggle for recognition, issues such as the global finance and debt campaign, disarmament and peace campaigns. ${ }^{430}$ The attempts made by such campaigns and movements along with the willingness to dialogue over the common fate of humanity reflects the possibility of making change in the political landscape for equal recognition.

Accordingly, it can certainly be argued that as a response to growing concerns about how to deal with new political, economic and social dimensions of the life-world transnational civil society has often operated successfully. ${ }^{431}$ Transnational civil society has become a hopeful horizon through which people and advocacy groups can be globally networked to put potential pressure on more powerful states to open up a new way for silenced voices to be equal participants in world affairs. The self-reflexive nature of transnational civil society has interconnected its components although they might never

\footnotetext{
429 In order to receive a full account of the emerging power shift see Kumi Naido, "Claiming Global Power: Transnational Civil Society and Global Governance," in Transnational Civil Society, Srilatha Batliwala and David L. Brown ed. (Bloomfield, CT.: Kumarian Press Inc., 2006), pp. 51-64; Catherine Barnes, "Weaving Web: Civil Society Roles in Working with Conflict and Building Peace," in People Building Peace II: Successful Stories of Civil Society, Paul Van Tongeren et al. ed. (London: Lynne Reinner Publishers, 2005). The power shift was used by Jessica T. Mathews in her article: "Power Shift," Foreign Affairs 76, no.1 (1997): 50-66. Also note that the Asian Development Bank and WTO have launched programs to dialogue with global civil society. See also the following sources to follow the interests of bankers to dialogue with the agents of transnational civil society: Grant Curtis, "The Asian Development Bank's Cooperation with NGOs and Civil Society," at http://www.istr.org/conferences/toronto/abstracts/Curtis.pdf; Jessica Wilson, "Why does the WTO need Civil Society?" at http://www.ictsd.org/dlogue/1999-02-10/WILSON.pdf.

${ }^{430}$ For detail of these issues see Alison Van Rooy, The Global Legitimacy Game; Civil Society, Globalization, and Protest (New York: Palgrave, 2004).

${ }^{431}$ The literature of civil society provides us with a number of stories of the successfulness of the agents of civil society in addressing solutions for global problems. See for example Sergey Ripinsky and Peter Van Den Bossche, NGO Involvement in International Organizations (London: British Institute of International and Comparative Law, 2007).
} 
meet and do not know each other. Civil society is neither defined in terms of nonintegration, nor is it stipulated as multiplicity within unity; rather it is perceived by players as a venue which can be set against older society. It is an ideal-type constructed reality serving the needs of new society across national boundaries with the deliberative aim of drawing the world together in new ways. Transnational civil society can stimulate awareness globally and put pressures from below on powerful states to give up in favor of substantial reform to world order and global governance. Global civil society can challenge the monopoly of frame-setting by powerful states and set the scene to dialogue on the advent of a new polity - a rooted cosmopolitan world - in which all take advantage of participation.

In sum, the advent of such a diverse world and possibility of advancing an allembracing insight for its management, allows one to reflect on the question of "who should recognize whom and how". My argument, briefly, is that a lack of willingness by greater powers to politically and institutionally recognize different others has resulted in the tragic practice of exclusion and oppression. In other words, the legal regime of recognition, which has been practiced in the past couldn't give justice to the oppressive world order in which the logic of power application through non-recognition has advantaged the stronger party at the expense of the weaker. There is no doubt that patterns of oppression and dominance have varied from case to case and from time to time, but the dynamism of oppression through non-recognition has not drawn the attention of the thinkers in the field of International Relations. Also, I would claim that the portrait of the just world polity drawn by a one-sided and monological language of dominant more powerful states has not been successful to open up a hopeful horizon for 
recognition and dialogue with different others. Justice in such a world of inequality, as long as it is not changed substantially, is no more than a failed illusion. Peace-loving and justice-advocating ideals then depend on the willingness to recognize politically - and be mutually recognized - and dialogue with others over an emerging embedded cosmopolitan world. In order to bring justice to the world, the current grammar of justice should be changed. Therefore, by asking such questions as "who should recognize", "what should be recognized" and "how" we answer the following: 1) the more powerful states should be willing 2) to "politically and institutionally" recognize different others 3) and at the level of global governance.

Transnational civil society can stimulate consciousness and mobilize civil society across-boundaries and put pressures on more powerful states to abandon nonrecognition, and hence oppression. This ideal can theoretically be accomplished through the force of emerging transnational civil society with potential political and ethical strength through which we attempt the advancement and realization of the mutual right to political recognition and then equal participation. The most appropriate and feasible dynamism for a recognition-based approach to justice is to open up windows in global governance for dialogue with different others on how to manage the life-world in a more just manner. Indeed, "global governance" must break with its monologue and turn into a "dialogical governance" through mutual recognition and dialogue. Such a prescriptive ideal could be possible due to the fact that powerful states are ceaselessly faced with the challenge of civil society within their territory and transnationally. Since powerful states are dependent on legitimacy, civil society agents can threaten that legitimacy to pressure them if they do not respond to the demands of people carried by civil society. 


\section{Recognition, Justice, and Solidarity}

If a recognition-base justice is promoted in global governance, it takes the form of an overlapping consensus among participants; this leads to a more durable solidarity in the life-world. If it is also taken as true that the challenge of global civil society weakens the consistency of monologue in international relations and instead empowers dialogue over the re-adjustment of the world order and global governance, the political will of the powerful states to recognize different others would promote peaceful coexistence and solidarity with intensive social cohesion and political strength. Such strength derives from an overlapping consensus, which has been constructed by all participants through dialogue and mutual recognition. Mutual recognition, indeed, builds up a more trusting peaceful coexistence in the life-world and is different from modus vivendi advanced through lenses of liberal pluralism, as well as reconciled co-existence promoted by realism. In recognition, priority is given to the will of nations to determine their own appropriate mode of meaningful life and encourages them to reciprocally assume the same right for other nations. Perceived in this way, the world is viewed as composed of self-determining and equal states each of which stands in a dialogue for recognition with the other. Dialogue allows differences to be fused in a common horizon, a shared internationally public sphere, and to increasingly strengthen an embedded solidarity. This solidarity has not been constructed based on the idea of "sameness" between powerful states; rather, it is built upon an all-encompassing agreement among all actors of different sorts to promote justice through recognition and inclusion. ${ }^{432}$

\footnotetext{
${ }^{432} \mathrm{~A}$ similar account of solidarity through recognition is admitted by Anselm K. Min, "From Difference to the Solidarity of the Others," Philosophy and Social Criticism 31, no. 7, (2005): 824.
} 
To promote solidarity, parties engaged in the overlapping consensus are to be pledged to mutual recognition and dialogue and for this aim they need openness as a means of learning from each other. This transparency is an open-ended process that bridges the differences between states and leads to a disposition to join the newly emerging embedded polity - a rooted cosmopolitan community - that is governed through dialogue and mutual recognition. The boundaries of this polity are not demarcated contractually in its Hobbesian sense, but rather are defined through a dialogical relationship over the shared experiences of socio-political life. In this polity the problematic of incommensurability originating from competing interests is surmounted through participatory parity; a "fusion of horizons" of interests of all parties. ${ }^{433}$ This ideal type of 'rooted cosmopolitanism' allows the self-controlled conservation of particular values of life and traditions of all participants except the particular cases which might prompt exclusion, non-recognition, and hence oppression. In a rooted cosmopolitanism style of life-world which is developed upon mutual recognition and dialogue, all nations are bound together due to the fact that they are different. Without difference and its recognition we cannot even define ourselves as nations ${ }^{434}$. Recognition opens the path ways through which different nations can share their commitment to solidarity without

\footnotetext{
433 This interpretation of incommensurability has been promoted by many readers of Taylor. For example see: Neil Levy, "Charles Taylor on Overcoming Incommensurability," Philosophy and Social Criticism 26, no. 5 (2000): p. 59; and Nicholas Smith, "Overcoming Representationalism" op. cit, pp. 29-43. ${ }^{434} 1$ owe this line of argument to Charles Taylor again. See Charles Taylor, "Interpretation and the Sciences of Man," in Philosophy and the Human Sciences (Cambridge: Cambridge University Press, 1985), p. 36. Similar to this idea, Taylor in another work promotes the idea that we cannot defines ourselves as men, except by binding together in a common cultural, linguistic, and/or confessional community. Also see Charles Taylor, "Identification and Subjectivity" in Political Thought, Michael Rosen and Jonathan Wolff ed. (Oxford; Oxford University Press, 1999); and Charles Taylor, "Democracy, Inclusive and Exclusive," in Meaning and Modernity: Religion, Polity, and Self, Richard Madsen ed. (Berkeley: University of California Press, 2001), pp. 181-194.
} 
being abstracted from their distinctiveness or stressing superiority over different others. ${ }^{435}$

In this account of recognition as justice and solidarity, difference in national identity is seen as a positive factor that enriches all parties. Mutual recognition also allows different nations a full range of human achievement and capacity through a dialogue with different others who have adopted their own different paths to identity. Recognition as justice and as a way to a reliable solidarity undermines the cause of fragmentation, hence it is to be seen as the source of a global social bond among nations. 


\section{Conclusion}

This thesis has sought to expose the insufficient attention paid to the concept of recognition in International Relations. The common and prevailing usage of this concept is the legal recognition which was advanced at the dawn of the Westphalian era to establish a mutually-beneficial international law system among the major players in international politics. At the base of this concept lies the idea that the states are legally equal, and hence can participate in international relations, as long as they are mutually recognized by one another regardless of their constitutional structure. This concept of recognition suffers from two major deficits that are highly questionable in today's world of critically awakening consciousness. The first one is related to the internal sphere. The existing regime and practice of recognition disregard whether the statehood of the recognized states has been achieved through democratic process, and whether the human rights of citizens are respected by the ruling states. ${ }^{436}$ There is, indeed, and in most of the cases, no relation between democratic values and the act and practice of the statehood. In today's world, almost all non-democratic states recognized by other states, as well as international community of states, are disrespectful of human rights and demand of their nationals for democracy, as it can be seen for example in Egypt, China, Saudi Arabia, and Iran. The rare acts of non-recognition taken place in the Cold or post Cold-War era, such as Taiwan, Cambodia, and Sudan, have been stirred up by political considerations than true concerns with democratic legitimacy of states.

\footnotetext{
${ }^{436}$ It must be noted that while in the formal sense and to some extent in practice of recognition human rights factor is ignored in the existing recognition, there is the case that, more and more, membership in international society, demands adherence to some minimum standards of human rights, etc. In spite of this demand, states may use this to their advantage, and often do by recognizing states when it suits them, and not recognizing them when it does not.
} 
In the international sphere, recognition has been a matter of benefit calculation of the stronger states, who determine who must be considered as the active member of the international we. In this atmosphere of instrumental practice and application of recognition, which is indeed a matter of being advantaged or disadvantaged, the act of formation of statehood does not necessarily mean becoming the active participation in the international life. That is to say, although the current international we system acknowledges the legal equality of all states, in practice it comprises only those who have been recognized by other states in light of some benefit calculations. And, it is only in this sense that the states would be capable of becoming the actual members as well as the effective right bearers and duty holders in the international life. That is why the existing doctrine and usage of recognition become questionable because it is a means of membership in a given hierarchical international we system in which active membership depends on the will and consideration of the stronger states. Indeed, although the current doctrine of recognition acknowledges the urgency of membership and by implication collaboration among states, in practice only those states are counted as true members of the international we system who are in some way aligned with the major players in the world politics.

Accordingly, the current usage of recognition reflects the discriminatory will of the more powerful states who, in their struggle for more power, marginalize and/or exclude different others -- those whose political will does not conform with the international system. The very intentional exclusion of others -- especially those aspiring to a more participatory and dignified existence -- inflicts harm and, consequently, injustice. Those who are deprived of their participatory rights in a just international society are denied the 
achievement of a dignified and righteous. In this way, recognition becomes a substantive conception in the idea of justice. That is to say justice depends essentially on recognition. In this case, recognition not only is a matter of the actualization of statehood and active participation in the life-world, but also is a key notion in paradigm of justice - hence the theory of recognition as justice. ${ }^{437}$

It follows that recognition and justice are intertwined. Justice is not possible without recognition of others and their distinct path to statehood and the life-world. Unwillingness to recognize the equal worth of different others constitutes the root cause of injustice. If the states are not recognized as equal and independent members of the international we, they are, indeed, deprived of their equal right to pursue their own original way to life. In other words, the absence of due recognition of those who pursue their own path to the formation of statehood as well as the effective self-determination means denial of their identity and thus, their exclusion.

By facilitating and accelerating the scope of the public sphere via the revolution in information and communication technology, the process of globalization undermines the strictness of the boundaries of the pre-determined international society. As a result of such transformations, the voices smoldered beneath the prevailing international system are empowered and provided with the opportunity to revolve around multiple poles with manifold purposes. One of the most interesting aspects of the implications of the process of globalization for social relations in general, and international relations in particular, is the

\footnotetext{
${ }^{437}$ In some of the text a similar idea has been discussed For example, in Justice, Community and Dialogue in International Relations, Richard Shopcott defines justice as recognition or justice through recognition He believes that recognition refers notably to the fundamental modes of being-in-the-world Here is that recognition adds an ontological dimension to the problem of justice whereby is related to recognition He move on and argues that justice is achieved by recognizing the particular manner in which different human beings identify themselves See Richard Shopcott, Justice, Community and Dialogue in International Relations (Cambridge Cambridge University Press, 2001), pp 10, 12, 26, and 56
} 
possibility of revolting against international society under the banner of struggle for recognition. As a result of networking and interconnection, and the de-territorialization of social relations, the voices which had been smoldering beneath the dominant international discourse have found the opportunity to come to the fore and struggle for recognition of their equal and participatory rights in international society. In the globalizing world, then, it is not without huge expenses to continue the one-sided struggle for power and/or the material benefits by superior states regarding the struggle for recognition of different others. Indeed, the process of globalization has provided the opportunity to turn upside down the traditional/legal recognition in favour of the due recognition or struggle for recognition as justice.

In light of these observations, recognition must not only be considered as the necessary condition for achieving an inclusionary and, hence, a more participatory international society, but also as a prerequisite for an accountable and peaceful life-world. The idea behind this claim is that without recognition as justice, that is the acknowledgment of the equality and participatory right of all nations in the discourse of life, the root cause of conflicts are undiagnosed and a trusted account of solidarity and peaceful life among nations could not be established. To put this differently, the unwillingness to engage in a mutual recognition results not only in pressing forms of inequality and injustice, but also in a fertile terrain for the growth of mistrust and, consequently, hostility and conflict. In the opposite way, deliberation on recognition of equality as a pathway to justice gives rise to a trusting engagement in international society and a more durable, peaceful co-existence among nations. 
Therefore, the current doctrine and practice of recognition, being grounded either on the liberal/legalist sense of it, or on the realist calculative assumptions, fails to confirm the distinct ways of the formation of the nationhood/statehood of different nations/states. That is why I argue that the importance of recognition in the sense which is presented in this dissertation must be universally practiced. The practice of recognition must include recognition as the necessary condition for the formation of the statehood and the relationship among states, on the one hand, and recognition of equal worth of states as a means of actualization of a participatory and, hence, just discourse of the life-world, on the other. The relationship between these two - recognition and democracy is universal and necessary; universal because it must be considered non-discriminatory and necessary because it must acknowledge the original way of different states to their statehood - or nations to their nationhood. ${ }^{438}$ Therefore, my interpretation of recognition, due to the very characteristics i.e., necessity and universality, connotes a categorical importance for a just international society. That is to say, it must never be conditioned to either the legalist or the realist approach to recognition because these approaches restrict acknowledgement of different others to the confine of the calculative provisions. ${ }^{439}$

Yet, such categorical importance is hardly acknowledged or articulated by both the mainstream and alternative perspectives in the study of international relations. Although in The Law of Peoples, for example, John Rawls moves toward a communitarian-like

\footnotetext{
${ }^{438}$ I use universal and necessary in explanation of the relation between recognition and justice to illustrate the categoncal imperative behind this relationship This means recognition applying to everyone That is to argue what is morally nght for one person is morally nght for everyone, which is what is meant by saying that the relationship between the two is universal This relationship is also necessary because recognition is not for the sake of some ends or goals, as it is seen from the view point of liberalism and realısm Rather, there is a duty to recognize This duty is not conditioned That is why I argue that relationship between the two must also be necessary

${ }^{439} \mathrm{I}$ acknowledge that the legalist account may provide a basis from which a more comprehensive approach to recognition is achieve However, such account of recognition still remains conditioned to liberal perspective, and consequently gives the way to nonrecognition of non-liberal societies
} 
acknowledgement of the existence of difference. No political and institutional recognition of different others - non-liberal people - is recommended. The only exception to this acknowledgment is when different others come into cooperation with well-ordered liberal societies. In addition, among almost all degrees and categories of non-liberal peoples, Rawls believes, only those of decent hierarchical people must be mutually recognized because they are bona fide members of the society of peoples. This recognition helps those societies one day become liberal. In other words, recognition helps those of the decent societies which are alienated and marginalized from the discourse of life - moving away from their own unique way of the nationhood/statehood and assimilating in liberalism, and consequently become the primary players in the society of peoples. In this account of recognition, Rawls shifts considerably away from the liberal notion of toleration and acknowledges the independence of the decent societies. By this shift, he confirms necessity of fair participation in the society of peoples. Notwithstanding, he conditions such recognition to a hope; decent people might one day become liberal. Indeed, Rawls articulates a hypothetical account of recognition which is conditioned to certain circumstances rather than a categorical account conveying the two principles of necessary and universality. His account of recognition narrows down the scope of recognition of different others and, consequently, exclude them the society of peoples.

As a response to narrowness of liberal perspective, alternative approaches extend beyond the restrictions of the hypothetical assumptions of the liberal account of recognition and heighten both the depth and extent of difference. These approaches question both the epistemological and ontological basis of liberalism and realism, thereby criticizing the Enlightenment project and the Westphalian model of the statehood. It is 
wrong, according to alternative approaches, to follow liberalism's conscious project of changing the distinctive way of the statehood of different states and their different background formation. From this perspective, the liberal approach to recognition is similar to proselytization. It does not connate learning to live together with deep differences and disagreements about distinct belief and views to life. Rather, it is an attempt, as we can see in the case of Rawls doctrine of recognition of decent peoples, to knowingly change someone else's mind about her self-definition or a nation's particular perspective of life. ${ }^{440}$ Specifically, liberalism refutes the thick conception of culture, and hence ignores the demands for recognition of identity and culture distinctiveness. Such ignorance might amount to alienation, mistreatment, and even non-recognition of distinct others.

Accordingly, communitarianism, post-foundationalism, and Critical Theory set their arguments against the narrowness of the liberal account of recognition. Within this perspective, recognition yields in acknowledgment of those who are aligned with liberalism. What happens, as the result of such narrowness, is that the ontological and cultural differences are ignored or reduced to the melting pot model of assimilation, communitarians argue. For communitarians of almost all sorts, the favorable and just discourse of the life-world is the one in which historical background in the formation of the nationhood/statehood is counted. In Etzioni's perspective, for example, the discourse of international life must not only embrace the universal principles, but also acknowledges the particularistic conceptions of the good life and cultural backgrounds of different nations. ${ }^{441}$

\footnotetext{
${ }^{440}$ Elshtain, "Toleration, Proselytization, and the Politics of Recognition The Self-Contested," p 127

${ }^{441}$ Etzionı, From Empire to Community: A New Approach in International Relations, p. 234.
} 
Postmodernism or post-structuralism advance the idea that we are surrounded by contending plurality of values and realities. There is, then, no given project of the life-world to follow. Rather, our changing world merits a meticulous contextualization of its concepts and a deliberate interpretation and confirmation of its plurality of meanings and its contingent difference. In this de-centralizing world of the constant change and transformation, the authenticity of identities and the equality of their cultural differences must be understood and acknowledged.

In the same token, and in spite of the differences in their perspectives, critical theory scholars favour a project of emancipation form the narrow confine of liberalism and realism. Following Habermas' account of communicative rationality, Linklater suggests a "critical turn" in the current situation in scholarship to illustrate the importance of culturally divergent identities and emphasizes the urgency of respect for cultural differences in modern international relations. ${ }^{442}$ He advances a conception of political community which is constructed based on an inclusive inter-dialogue relation among culturally distinctive identities. Being cosmopolitan in its nature and scope, this community acknowledges the difference and maximizes inclusion of different others irrespective of their racial, national, and other characteristics. ${ }^{443}$

Although ground-breaking in their perspectives, alternative approaches only acknowledge the existence of difference rather than the political recognition of the participatory right of different others in international society and global governance. And

\footnotetext{
${ }^{442}$ Linklater, "The Question of Next Stage in International Relations Theory: A Critical-Theoretical Point of View," pp. 23-37.

${ }^{443}$ Andrew Linklater, "The Question of Next Stage in International Relations Theory: A Critical-Theoretical Point of View," Millennium Journal of International Studies 21, no. 1 (March 1992). Also see Andrew Linklater, "Men and Citizens in International Relations," Review of International Studies 7 (1991).
} 
although innovative in opening a critical reflection on the rationale behind the Westphalian international relations, alternative approaches do not consider recognition as a path way to justice. It is, therefore, imperative to extend beyond these restrictions in acknowledgment of difference and open up new a horizon to reflect upon the question of how to do justice to equal worth of different others and the ways through which they can effectively participate in re-definition and articulation of the we-ness of the of the life-world; reformulation of a new and inclusionary international we.

The hope for a new we may come true when due recognition is considered as a vital need for the acknowledgment of the statehood and as a pathway to justice. In this dissertation, I argue that Charles Taylor's account of recognition appropriately addresses the need and urgency to recognize different others and their rights. Recognition in the sense which is theorized by Taylor is more than the mere toleration or recognition as courtesy. It is also beyond the mere acknowledgment of difference as confirmed by alternative approaches. It is, rather, a public and political recognition of identity and cultural differences through which the way to a just social relation is paved. It also entails the creation of social institutions and arrangements through which all members of society interact with one another based on their equal worth and rights to participate in the international society without being abstracted from their distinctiveness. From this perspective, misrecognition and nonrecognition inflict grave harm and cause injustice. ${ }^{444}$ On the opposite way, due recognition not only addresses the struggle for recognition as a vital need in the formation of identity - as well as nationhood/statehood - but also constitutes a firm ground for theorizing a new conception of justice -- recognition as justice.

${ }^{444}$ Taylor, "The Politics of Recognition," p. 226. 
Within this perspective, failure to recognize imprisons different others and distorts their original mode of life, and denies them a dignified life and the participatory right in the international society. It is not surprising though that the struggle for recognition has becoming a driving force behind the most of the current resurgence against the preestablished international order, as it can be seen in the case of the southern countries challenging the heritage of the North. In light of these observations, due recognition must be considered as both a vital need in the construction of the identity and a fundamental factor in the definition of justice. Being viewed from this perspective, recognition must also be regarded as a fertile ground for a trustable social formation and relations. These three functions of the theory of recognition provide a solid intellectual terrain to set recognition as a diagnosing device as well as a solution for the existing unjust international relations.

Having discussed the theoretical advantages and the decisive importance of recognition for international relations, we are still facing a dilemma in application of recognition; who must recognize whom, and how? The argument pertains to those more powerful states who manage the process of planning of global governance. These states are to be responsible for re-adjustment of the international society. This responsibility derives from their perfect duty to acknowledge equal worth of other states and necessitates openness for substantial dialogue over an all-encompassing participatory model. They also have an imperfect duty to assist others in comprehension of their participatory right in the re-articulation of a just discourse of the life-world in accordance which a more democratic and transparent pattern of political and institutional order is advanced. These duties stem from a numerous bonding legal instruments articulated by the institutions of global governance among them the United Nations and impose obligations upon states to respect 
and recognize each other's equality and participatory rights in international relations. Since the states members of the international society have consented these instruments and have been committed themselves to them, these instruments are the source of their duties to recognize different others. And, that is the very commitments that produce the 'perfect' duty to recognize. Since the gravity of these documents falls into the legal recognition of equality of all states without stipulation of any differences, such equality must also be politically acknowledged by all without any discrimination. It follows that duty to recognize is perfect and must be rigorously observed.

Still, the benefit-oriented mind and selfish behaviour of the more powerful states enjoying their privileged status within international society resist the struggle for recognition and aspiration for a more just world. In response to this unfortunate atmosphere of domination/subordination, I assume that the institutions of civil society from inside and outside can pressure the bigger states to review their self-centered position toward the acknowledgment of the equal worth and participatory right of others in managing of the world. These pressures give urgency to broadening the scope of the public sphere within states, on the one hand, and facilitating the radical forms of transnational mobilization and socialization outside, on the others. This double pressure further escalates the breadth and scope of the demand for de-politicization of and transparency in the process of decision-making in managing of the world. Becoming gradually popular in the crafting of a more inclusionary international society, this double pressure might be accompanied by an account of prudence of the superior states who are concerned with their own reputation. Reputation, for these states, is instrumental in achieving their goals. Therefore, civil society's resistance against the superior powers is compelling and can 
potentially dismantle their struggle for power and material benefits in favor of struggle for recognition.

Although such crafting of pressure on the managers of the existing world politics might not be truly compelling, there is still a hope that the good will of some of the stronger states motivates them triggering the re-adjustment of the pre-determined world eventually leading to the recognition of the equal worth and participatory rights of different others. There is evidence of such hope in today's world. Although this evidence is not necessarily related to the issue of recognition, we can see an account of generosity by some of the countries willing to make some changes in the world. ${ }^{445}$ There are also other indications of success such as the cooperation of the Asian Development Bank with NGOs and civil society promoting the hope on the good will and generosity as the factors affecting the unjust world order.

\footnotetext{
${ }^{445}$ Of the clearest example of this generous tendency can be seen ns Canadian foreign policy objectives and attempts to make changes in the world among them a new diplomacy enhancing prospects for nation-building and reconstruction with the hope of assisting the other nations in a coordinated and effective way.
} 


\section{BIBLIOGRAPHY}

\section{Consulted Books \& Chapters}

Albrow, Mathew, "Globalization, Knowledge and Society," in Globalization, Knowledge and Society, Mathew Albrow and E. King ed. (London: Sage, 1990).

Annan, Kofi, We the Peoples: The Role of the United Nations in the 21 ${ }^{\text {st }}$ Century (New York: United Nations Department of Public Information, 2000).

Appadurai, Arjun, Modernity at Large: Cultural Dimensions of Globalization (Minneapolis. Minn.: University of Minnesota Press, 1996).

Appiah K. Anthony, "Identity, Authenticity, Survival: Multicultural Societies and Social Reproduction," in Multiculturalism and Politics of Recognition, Amy Guttmann ed. (Princeton, New Jersey: Princeton University Press, 1992).

Baker Gideon, Civil Society and Democratic Theory, Alternative Voices (London and New York: Routledge, 2002).

Barber R. Benjamin, "Can Democracy Survive Globalization in an Age of Terrorism," in Community Values in an Age of Globalization, Marsh P. Hansen, Alex Barber and David Cassels ed. (Calgary: Sheldon M. Chumir Foundation for Ethics in Leadership, 2002).

Barkan, Elazar, The Guilt of Nations: Restitution and Negotiating Historical Injustices (New York, Norton, 2000).

Barners, Catherine, "Weaving Web: Civil Society Roles in Working with Conflict and Building Peace," in People Building Peace II: Successful Stories of Civil Society, Paul Van Tongeren et al. ed. (London: Lynne Reinner Publishers, 2005)

Barry, Brian, "International Society from a Cosmopolitan Perspective," in International Society: Divers Ethical Perspectives, Terry Nardin and David Mapel ed. (Princeton: Princeton University Press, 1998).

Bauman, Zygmunt, Globalization: The Human Consequences (New York: Columbia University Press, 1998).

-, "The Great War of Recognition," in Recognition and Difference: Politics, Identity, Multiculturalism, Scott Lash and Mike Featherstone ed. (London: SAGE Publication Ltd, 2002).

Beck, Ulrich and Willms, Johannes, Conversations with Ulrich Beck (Cambridge: Polity Press, 2000). 
-, What is Globalization? (Cambridge: Polity Press, 2000).

Behagwati, Jagdish, In Defense of Globalization (New York: Oxford University Press, 2004).

Berlin, Isaiah, Vico and Herder: Two Studies in the History of Ideas (London, Chatto \& Windus, 1976).

-, Three Critics of the Enlightenment: Vico, Hammann, Herder (Princeton, New Jersey: Princeton University Press, 2000).

-, Two Concepts of Liberty: An Inaugural Lecture Delivered Before the University of Oxford (Oxford: Clarendon Press, 1958).

Berlinski, Claire, There Is No Alternative: Why Margaret Thatcher Matters (New York: Basic Books, 2008).

Braveboy-Wagnr, Jacqueline Anne, The Foreign Policies of the Global South: Rethinking Conceptual Frameworks (Boulder, Colo.: Leynne Rienner Publishers, 2003).

Brock, Gillian and Moellendor, Darrel ed., Current Debates in Global Justice (Dordrecht, Netherlands; Norwell, MA: Springer, 2005).

Brown, Chris, "Critical Theory and Postmodernism," in Contemporary International Relations Theory, A.J.R. Groom ed. (London: Pinter Publishers, 1994).

-, International Relations Theory: New Normative Approaches (New York: Harvester Wheatsheaf, 1992).

Bryant, Christopher and Jary, David ed., Giddens Theory of Structuration: A Critical Appreciation (London; New York: Routledge, 1991).

Burgerman, Susan, Moral Victories: How Activists Provoke Multilateral Action (Ithaca: Cornell University Press, 2001.).

Castells, Manuel, The Rise of the Network Society (Cambridge, MA: Blackwell Publishers, 1996).

Calhoun J., Craig, Critical Social Theory: Culture, History, and the Challenge of Difference (Oxford, UK; Cambridge, USA: Blackwell, 1995).

Campbell, David, Writing Security: United States Foreign Policy and the Politics of Identity (Manchester: Manchester University Press, 1992). 
Chakrabarty, Dipesh, Provincializing Europe: Postcolonial Thought and Historical Differences (Princeton, N.J.: Princeton University Press, 2000).

Chernoff, Fred, The Power of International Theory: Reforging the Link to Foreign Policy Making Through Scientific Inquiry (London: Routledge, 2005).

Clark P. Robert, Global Awareness, Thinking, Systematically about the World (Lanham: Rowman and Littlefield Publishers, Inc., 2002).

Cochran, Molly, Normative Theory in International Relations (Cambridge: Cambridge University Press, 1999).

Connolly, William, Identity/Difference: Democratic Negotiations of Political Paradox (New York: Cornell University Press, 1991).

-, The Ethos of Pluralization (Minneapolis: University of Minnesota Press, 1995).

Cox, Robert, The Political Economy of a Plural World: Critical Reflections on Power, Morals, and Civilization (New York: Routledge, 2002).

Croucher L., Sheila, Globalization and Belonging: the Politics of Identity in a Changing World (Lanham: Rowman and Littlefield Publishers, 2004).

Crawford, Neta, Argument and Change in World Politics: Ethics, Decolonalization, and Humanitarian Intervention (Cambridge: Cambridge University Press, 2000).

Dahl, Robert, "Can International Organizations be Democratic" A Skeptic View," in Democracy's Edge, lan Shapiro and Casiano Hacker-Cordón ed. (London ; New York : Cambridge University Press, 1999), pp. 19-36.

Dallmayre, Fred, Achieving our World: Toward a Global and Plural Democracy (Lanham, Maryland: Rowman \& Littlefield Publishers, Inc., 2001).

De Beus, Jos, "Does Equality Travel? A Note on the Institutional Preconditions of Global Equality," in The Ends of Globalization: Bringing Society Back in, edited by Don Kalb and et al. (London: Rowman and Littlefield Publishers, 2000).

DeChaine, Daniel Robert, Global Humanitarianism: NGOs and the Crafting of Community (Lanham, MD: Lexington Books, 2005).

Deely N. John, New Beginnings: Early Modern Philosophy and Postmodern Thought (Toronto: University of Toronto Press, 1994). 
Der Derian, James, International/Intertextual Relations, James Der Derian and Michael Shapiro ed. (Washington D.C.: Lexington Books, 1989).

Devetak, Richard, "Critical Theory," in Theories of International Relations, Scott Burchill et al ed. (New York: St. Martin's Press, 1996).

Dunne, Tim, "Liberalism," in The Globalization of World Politics: An Introduction to International relations, John Baylis and Steve Smith (Oxford: Oxford University Press, 2005).

Dyck J., Arthur, Rethinking Rights and Responsibilities: the Moral Bonds of Community (Cleveland, Ohio: Pilgrim Press, 1994).

Etzioni, Amitai, Security First: for a Muscular, Moral foreign Policy (New Haven: Yale University Press, 2007).

-, From Empire to Community: A New Approach in International Relations (New York:

Palgrave Macmillan, 2004).

-, "The emerging global normative synthesis," Journal of Political Philosophy 12, no. 2 (2004): 214-244.

Evangelista, Matthew, Unarmed Forces: The Transnational Movement to End the Cold War (Ithaca, NY: Cornell University Press, 1999).

Falk, Richard "Resisting Globalization from Above through Globalization from Below," in Globalization and the Politics of Resistance, B. Gills ed. (London: Macmillan, 2000).

-, "The UN and Cosmopolitan Democracy," in Re-imagining Political Community, Daniele Archibugi, David Held, and Martin Kohler ed. (Cambridge: Polity Press, 1998), pp. 309331.

-, "The Making of Global Citizenship," in Global Visions: Beyond the New World Order, Jeremy Brecher, John B. Childs, and Jill Cutler ed. (Boston: South End Press, 1993), pp. 3952 .

Ferrara, Alessandro, Modernity and Authenticity (Albany: SUNY Press, 1993).

Florini, Anne, The Third Force; The Rise of Transnational Civil Society (Tokyo, Japan Center for International Exchange., 2000).

Foot, Rosemary, Gaddis John Lewis, Hurrell, Andrew, ed., Order and Justice in International Relations (Oxford; New York: Oxford University Press, 2003).

Forster N. Michael ed., Herder Political Writings (Cambridge: Cambridge University Press, 2002). 
Foster, Lawrence and Herzog Patricia eds. Defending Diversity: Contemporary Philosophical Perspectives on Pluralism and Multiculturalism (Amherst: University of Massachusetts Press, 1994).

Foucault, Michael, Power/Knowledge: Selected Interviews and Other Writings 1972-1977, Colin Gordon ed. (New York: Pantheon Books, 1972).

Fraser, Nancy, "Recognition as Justice? A Proposal for Avoiding Philosophical Schizophrenia," in Law, Justice, and Power between Reason and Will, Sinkwan Cheng ed., (Stanford: Stanford University Press, 2004), pp. 139-57.

-, Justice Interruptus: Critical Reflections on Post-Socialist Condition (New York: Rutledge, 1997).

Friedman, Thomas, The Lexus and the Olive Three (New York: Farrar, Straus \& Giroux, 2000).

Frohnen, Bruce, The New Communitarians and the Crisis of Modern Liberalism (Lawrence: University Press of Kansas, 1996).

Frost, Mervyn, Constituting Human Rights: Global Civil Society and the Society of Democratic States (New York: Routledge, 2000).

-, Ethics in International Relations: A Constitutive Theory (Cambridge: Cambridge University Press, 1996).

Gadamer, Hans-Georg, Truth and Method, Joel Weinsheimer and Donald G. Marshall trans. (London: Continuum, 1975).

Gehring, Verna, Ethical Dimensions of Global Development (Lanham: Rowman \& Littlefield Publishers, 2007).

George, Jim, Discourses of Global Politics: A Critical (Re) Introduction to International Relations (Boulder, Colo.: Rienner, 1994).

Gewirth, Alan, The Community of Rights (Chicago: Chicago University Press, 1996).

Giddens, Anthony, Runaway World (New York: Routledge, 2000),

-, Modernity and Self-Identity: Self and Identity in the Late Modern Age (Cambridge: Polity Press, 1991).

-, The Consequences of Modernity (Stanford: Stanford University Press, 1990).

Gideon, Baker, Civil Society and Democratic Theory, Alternative Voices (London and New York: Routledge, 2002). 
Grovogui, Siba, Beyond Eurocentrism and Anarchy, Memories of International Order and Institutions (New York: Pargrave Macmillan, 2006).

Habermas, Jürgen, Philosophy in a Time of Terror: Dialogues with Jürgen Habermas and Jacques Derrida, interviewd by Giovanna Borradori (Chicago: University of Chicago Press, 2003).

-,"Postnational Constellation," in The Global Transformations a Reader: An Introduction to Globalization Debate, David Held and Anthony McGrew ed. (Cambridge, UK: Polity Press; Malden, MA USA, 2003), pp. 542-546

-, Moral Consciousness and Communicative Action (Cambridge: The MIT Press, 1990).

-, Structural Transformation of the Public Sphere: An Inquiry into a Category of Bourgeois Society, Thomas Burger trans. (Cambridge, Mass.: MIT Press, 1989).

-, Philosophical Discourses of Modernity (Cambridge: Cambridge University Press, 1987).

-, Theory and Practice (Boston, Eacon Publishers, 1973).

-, Knowledge and Human Interests, Jeremy Shapiro trans. (Boston: Beacon Press, 1968).

Hall, Stuart, "The West and the Rest," in Culture, Globalization, and the World System, Anthony D. King ed. (Minneapolis: University of Minnesota Press, 1997.

-, Knowledge and Human Interests, Jeremy Shapiro trans. (Boston: Beacon Press, 1968).

-, "Old and New Identities, Old and New Ethnicities," in Culture, Globalization and the World-System, Anthony D. King ed. (Minneapolis: University of Minnesota Press, 1997).

-, "New Cultures for Old," in A Place in the World? Places, Cultures and Globalization, D. B. Massey and P. M. José ed. (Oxford: Open University, 1995).

Harvey, David, The Conditions of Postmodernity (Cambridge: Basil Blackwell, 1990).

Hegel G. W. F. Phenomenology of Spirit, translated by A. V. Miller (Oxford: Clarendon Press, 1977).

Hekman, Suzan, "Feminism," The Routledge Companion to Critical Theory, Simon Malpas and Paul Wake ed. (London; New York: Routledge, 2006), pp. 91-101. 
Held, David, "The Transformation of Political Community: Rethinking Democracy in the Context of Globalization," in Democracy's Edges, Ian Shapiro and Casiano Hacker-Cordbn ed. (Cambridge, UK: Cambridge University Press, 1998).

-, Democracy and Global Order: from the Modern State to Cosmopolitan Governance (Cambridge: Polity Press, 1995).

-, Daniel Archibugi, and Martin Kohler ed., Re-imagining Political Community: Studies in Cosmopolitan Democracy (London: Polity Press, 1998).

Herder, Johann Gottfried, Outlines of a Philosophy of the History of Man, T. Churchill trans. (London: Luke Hanford, 1803).

-, Yet Another History of Philosophy, F. M. Barnard trans. (Cambridge: Cambridge University Press, 1969).

Higgott, Richard, Underhill, Geoffrey R.D. Bieler, Andreas ed. Non-State Actors and Authority in the Global System (London; New York: Routledge, 2000).

Hugo A. Meynell, Postmodernism and the New Enlightenment (Washington: The Catholic University of America Press, 1999); John N. Deely, New Beginnings: Early Modern Philosophy and Postmodern Thought (Toronto: University of Toronto Press, 1994).

Huntington, Samuel, The Clash of Civilizations (New York: Simon \& Schuster, 1996).

Inayatullah, Naeem and Blaney, David, International Relations and the Problem of Difference (New York: Routledge, 2004), pp. 122-123.

Isbister, John, Promises Not Kept: Poverty and the Betrayal of Third World Development, Sixth edition (Bloomfield, Kumarian Press Inc., 2003).

Jardine, Murray, "Are Communitarians Premodern or Postmodren? The Place of Communitarian Thought in Contemporary Political Theory," in Community and Political Theory Today, Peter Augustine Lawber and Dale McConkey ed. (Westport, Conn.: Praeger, 1998).

Jarvis D. S. L., International Relations and the Challenge of Postmodernism: Defending the Discipline, (University of South Carolina Press, 2000).

Jones, Richard Wyn ed., Critical Theory and World Politics (Boulder, CO: Lynne Rienner Publishers, 2001).

Kaldor, Mary, Human Security: Reflections on Globalization and Intervention (Cambridge, UK; Malden, MA: Polity, 2007). 
-, "Transnational Civil Society," in Human Rights in Global Politics, Tim Dunne and Nicholas J. Wheeler ed. (Cambridge: Cambridge University Press, 1999).

Kant, Immanuel, Groundwork of the Metaphysics of Morals: On a Supposed Right to Lie because of Philanthropic Concerns, third edition, James W. Ellingtoned. (Indianapolis/Cambridge: Hackett Publishing Company, Inc., 1993).

Keane, John, Global Civil Society (Cambridge: Cambridge University Press, 2003),

Keily, Ray "Global Civil Society and Spaces of Resistance," in Global Ethics and Civil Society, John Eade and Darren 0'Byrne ed. (Berlington, VT.: Ashgate, 2005), pp. 138-153.

Keck, Margaret and Sikkink, Kathryn, Activists beyond Borders: Advocacy Networks in International Politics (Ithaca, N.Y.: Cornell University Press, 1998).

Keohane, Robert Owen, "Hobbes's Dilemma and Institutional Change in World Politics: Sovereignty in International Society," in Power and Governance in a Partially Globalized World (London; New York: Routledge, 2002), pp. 63-87.

Keohane, Robert, Hass, P. and levy M., ed., Institutions of the Earth (Cambridge, Mass.: MIT Press, 1993).

Kennedy, Paul, "Globalization and the Crisis of National Identity," in Globalization and National Identity: Crisis or Opportunity, Paul Kennedy and Catherine J. Danks ed. (New York: Palgrave, 2001).

Keyman E. Faut, Globalization, State, and Identity/Difference: Toward a Critical Social Theory of International Relations (New Jersey, Humanities Press International Inc., 1997).

Khargram, Sanjeev, Ricker, james, and Sikkink, Kathryn ed., Restructuring World Politics: Transnational Social Movements, Networks, and Norms (Minneapolis: University of Minnesota Press, 2002).

Kingsbury, Benedict, "Sovereignty and Inequality," in Inequality, Globalization, and World Politics, Andrew Hurrell and Ngaire Woods ed. (Oxford ; New York : Oxford University Press, 1999), pp. 66-94.

Laitinen, Arto, "Culturalist Moral Realism," in Perspectives on the Philosophy of Charles Taylor, Arto Laitinen and Nicholas H. Smith ed. (Helsinki: Societas Philosophica Fennica, 2002).

Lash, Scott and Featherstone, Mike ed., Recognition and Difference: Politics, Identity, Multiculturalism (SAGE Publications Ltd., 2002). 
Linklater, Andrew, The Transformation of Political Community: Ethical Foundations of the Post-Westphalian Era (Columbia: University of South Carolina Press, 1998).

-, Boundaries in Question: New Directions in International Relations ( London: Pinter, 1995).

McGrew, Anthony, "Globalization and Global Politics," in The Globalization of World Politics: An Introduction to International Relations (New York: Oxford University Press, 2005).

Mead, Herbert George, Mind, Self and Society from the Standpoint of a Social Behaviorist (Chicago: University of Chicago Press, 1934).

Miller, David, "Against Global Egalitarianism," in Current Debates in Global Justice, Gillian Brock and Darrel Moellendorf ed. (Dordrecht, Netherlands: Springer, 2005).

-, "National Responsibility and International Justice," in The Ethics of Assistance: Morality and the Distant Needy (Cambridge: Cambridge University Press, 2004), pp. 123-43.

Munck, Ronaldo, Globalization and Social Exclusion: A Transformationalist Perspective (Bloomfield, CT: Kumarian Press, 2005).

Naido, Kumi, "Claiming Global Power: Transnational Civil Society and Global Governance," in Transnational Civil Society, Srilatha Batliwala and David L. Brown ed. (Bloomfield, CT.: Kumarian Press Inc., 2006), pp. 51-64.

Nanz, Patrizia and Steffect, Jens, "Global Governance, Participation, and the Public Sphere," in Global Governance and Public Accountability, David Held and Mathias Koenig-Archibugi ed. (Malden, MA: Blackwell Pub., 2005), pp. 190-211.

Ned Lebow, Richard, The Tragic Vision of Politics: Ethics, Interests and Orders (Cambridge: Cambridge University Press, 2003).

Ohmae, Kenichi, The Borderless World: Power and Strategy in the Interlinked Economy (New York: HarperCollins Publishers, 1999).

Pogge, Thomas, "Real World Justice," in Current Debates in Global Justice, Gillian Brock and Darrel Moellendorf ed. (Dordrecht, Netherlands: Springer, 2005), pp. 29-35.

-, World Poverty and Human Rights: Cosmopolitan Responsibilities and Reforms (Cambridge: Polity Press, 2002). 
-, World Poverty and Human Rights: Cosmopolitan Responsibilities and Reforms (Cambridge: Polity Press, 2002).

Rawls, John, A Theory of Justice (Cambridge, Mass.: Harvard University Press, 1971).

-, Political Liberalism (New York: Columbia University Press, 1993).

-, The Law of Peoples (Cambridge, Mass.: Harvard University Press, 1999).

Reus-Smit, Christine, "Constructivism," in, Theories of International Relations, S. Burchill et al., ed. (Houndsmill: Palgrave, 2001).

Robertson, Ronald, "Globalization: Time-Space and Homogeneity-Heterogeneity," in Global Modernity, Mike Featherstone, Scott Lash, and Ronal Robertson ed. (London, Thousand Oaks, New Delhi: SAGE Publications, 1995).

-, Globalization: Social Theory and Global Culture (London: SAGE Publications, 1992).

Rosenau N. James, Distant Proximities: Dynamics beyond Globalization (Princeton: Princeton University Press, 2003).

-, "The Drama of Human Rights in a Turbulent world," in Globalization and Human Rights, Alison Brysk ed. (Berkeley: University of California Press, 2002).

-, "Beyond Post-internationalism," in Pondering Postinternationalism: A Paradigm Shift for the Twenty-First Century, Heidi H. Hobbs ed. (Albany: State University of New York, 2000).

Said W. Edward, Culture and Imperialism (New York: Alfred A. Knopf, 1994).

-, Orientalism (London: Routledge and Kegan Paul, 1978).

Sandel, Michael, ed., Liberalism and its Critics (New York: New York University Press, 1984).

-, Liberalism and Limits of Justice (Cambridge: Cambridge University Press, 1982).

Sassen, Saskia, The Mobility of Labor and Capital (Cambridge: Cambridge University Press, 1998).

-, Losing Control? Sovereignty in an Age of Globalization (New York: Columbia University Press, 1996).

Scholte J. Aart, "Globalization: Prospects for a Paradigm Shift," in M. Shaw ed., Politics and Globalization: Knowledge, Ethics, and Agency (London: Routledge, 1999). 
-, "Globalization and Collective Identities," in Identities in International Relations, Jill Krause and Neil Renwick ed. (New York: Saint Martin's Press, 1996).

-, "Beyond the Buzzword: Towards a Critical Theory of Globalization," in Globalization: Theory and Practice, Eleonore Kofman and Gillian Youngs ed. (New York: Pinter, 1996).

Shapcott, Richard, Justice, Community, and Dialogue in International Relations (Cambridge: Cambridge University Press, 2001).

Smith, Anthony, "Towards a Global Culture" in Global Culture: Nationalism, Globalization, and Modernity, Mike Featherstone ed. (London: SAGE, 1990), pp. 171-192.

Smith H. Nicolas, Charles Taylor: Mining, Moral, and Modernity (Oxford, UK: Blackwell Publishers Ltd, 2002).

Steffek, Jens, Embedded Liberalism and its Critics: Justifying Global Governance in the American Century (New York: Palgrave Macmillan, 2006).

Strange, Susan, "The Erosion of the State." In Crosscurrents International Relations in the Post-Cold War Era, edited by Mark Charlton. Scarborough, Canada, Thomson Canada Limited, 2002.

Sutch Peter, Ethics, Justice, and International Relations, Constructing an International Community (New York: Routledge, 2001).

Taylor, Charles, "On Identity, Alienation and the Consequences of September 11 $1^{\text {th, " in }}$ Perspectives on the Philosophy of Charles Taylor, Arto Laitinen and Nicholas H. Smith ed. (Helsinki: Societas Philosophica Fennica, 2002), pp. 165-95.

—, "Democracy, Inclusive and Exclusive," in Meaning and Modernity: Religion, Polity, and Self, Richard Madsen et al. ed. (Berkeley, California: University of California Press, 2002), pp. 181-194.

-, "In Defense of Positive Freedom," in Political Thought, Michael Rosen and Jonathon Wolff ed. (Oxford: Oxford University Press, 1999).

-, "Conditions of an Unforced Consensus on Human Rights," in The East Asian Challenge for Human Rights, Joanne R Bauer and Daniel A. Bell ed. (Cambridge: Cambridge University Press, 1999), pp. 124-44.

-, "Living with Difference," in Debating Democracy's Discontent: Essays on American Politics, Law, and Public Philosophy, Anita L. Allen and Milton C. Regan ed. (Oxford: Oxford University Press, 1998), pp. 212-26. 
-, "The Politics of Recognition," in Philosophical Arguments (Cambridge, MA: Harvard University Press, 1995).

-, "A Most Peculiar Institution," in World, Mind, and Ethics: Essays on the Ethical Philosophy of Bernard Williams, J.E.J. Althon ed. (New York: Cambridge University Press, 1995), pp. 132-55.

-, "To Follow a Rule," in C. Calhoun, E. Lipuma, and P. Moishe ed., Bourdieu: Critical Perspectives (London: Polity Press, 1993), pp. 35-45.

-, The Ethics of Authenticity (Cambridge: Harvard University Press, 1991).

-, "The Dialogical Self," in The Interpretive Turn: Philosophy, Science, and Culture, David R. Hiley, James F. Bohman, and Richard Shusterman ed. (Ithaca: Cornell University Press, 1991), pp. 304-14.

-, "Comments and Replies," Inquiry: An Interdisciplinary Journal of Philosophy 34 (1991): 237-54.

-, Sources of the Self: The Making of the Modern Identity (Cambridge: Cambridge University Press, 1989).

-, "Hegel's Ambiguous Legacy for Modern Liberalism," Cardozo Law Review10 (1989): 857-70.

-, Human Agency and Language: Philosophical Papers (Cambridge: Cambridge University Press, 1985).

—, "Atomism," in Philosophical Papers, volume ii (Cambridge: Cambridge University Press, 1985).

-, "Alternative Future: Legitimacy, Identity and Alienation in Late Twentieth Century Canada," in Constitutionalism, Citizenship and Society in Canada, A. Cairns and C. Williams ed. (Toronto: Toronto University Press, 1985), pp. 183-229.

-, "Hegel, History and Politics," in Liberalism and Its Critics, Michael Sandel ed. (New York: New York University Press, 1984), pp. 177-99.

-, "Political Theory and Practice," in Social Theory and Political Practice, Christopher Lloyd ed. (Oxford: Clarendon Press, 1983), pp. 61-85.

-, "What's Wrong with Negative Liberty," in The Idea of Freedom: Essays in Honour of Isaiah Berlin, Alan Ryan ed. (Oxford: Oxford University Press, 1979), pp. 175-93. 
-, "Hegel's Sittlichkeit and the Crisis of Representative Institutions," in Philosophy of History and Action, Yirmiahu Yovel ed. (Dordrecht: Reidel, 1978), pp. 133-54.

Thompson, Janna, Taking Responsibility for the Past: Reparation and Historical Injustice (Cambridge: Polity Press, 2002).

Trouillot, Michel-Rolph, "The Perspective of the World: Globalization Then and Now," in Beyond Dichotomies, Elizabeth Mudimbe-Boyi ed. (Albany: State University of New York Press, 2002).

Varughese, Anil Mathew, "Globalization versus Authenticity?" in Civilizing Globalization: A Survival Guide, Richard Sandbrook ed. (Albany: SUNY Press, 2003), pp. 53-58.

Walker J. B. Rob, Inside/Outside: International Relations as Political Theory (Cambridge: Cambridge University Press, 1993).

-, ed., Contending Sovereignties: Redefining Political Community (Boulder, CO: Lynne Rienner, 1990).

Walzer, Michael, The Company of Critics: Social Criticism and Political Commitment in the Twentieth Century (New York: Basic Books, 1998).

-, Thick and Thin: Moral Argument at Home and Abroad (New York: University of Notre Dame Press, 1994).

-, Spheres of Justice: A Defense of Pluralism and Equality (New York: Basic Books, 1983).

-, Just and Unjust Wars: a Moral Argument with Historical Illustrations (New York: Basic Books, 1977).

Wapner, Pauil, Principled World Politics: The Challenge of Normative International Relations (Lanham, Md.: Rowman \& Littlefield Publishers, 2000).

Willett Cynthia ed., Theorizing Multiculturalism: A Guide to the Current Debate (Malden, Mass: Blackwell, 1998).

Williams, Robert, Beyond Liberalism and Communitarianism: Studies in Hegel's Philosophy of Right (Albany: State University of New York Press, 2001).

-, Recognition: Fichte and Hegel on the Other (Albany: State University of New York Press, 1992).

-, Hegel's Ethics of Recognition (Berkeley: California University Press, 1997). 


\section{Journals and Periodicals}

Adler, Emanuel, "Seizing the Middle Ground: Constructivism in World Politics," European Journal of International Relations 3 no. 3 (1997): 319-63.

Armstrong, David, "Law, Justice and the Idea of World Society," International Affairs 75, no. 43 (1999): 547-561.

Ashley, Richard and Walker, R.B.J. "Reading Dissidence/Writing the Discipline: Crisis and the Question of Sovereignty in International Studies," International Studies Quarterly 34 (1990): 367-416.

-, "Untying the Sovereign State: A Double Reading of the Anarchy Problematic," Millennium Journal of International Studies 17 (1988): 227-62.

Barber, Benjamin, "Can Democracy Survive Globalization," Government and Opposition 35 , no. 3 (2000): 275-301.

Barry, Christian and Vanlentini, Laura, "Egalitarian Challenges to Global Egalitarianism: A Critique," Review of International Studies 35 (2009): 45-512.

Bauman, Zygmunt, "A Postmodern Grid of the Worldmap?" Critique \& Humanity (2002). This document is available at: www.eurozine.com.

Beck, Ulrich, Wolfgang Bonss and Christoph Lau, "The Theory of Reflexive Modernization: Problematic, Hypotheses and Research Programme," Theory, Culture and Society 20, no. 2 (2003): 1-33.

-, "Cosmopolitan Society and its Enemy," Theory, Culture \& Society 19, no. 1 (2002).

Benhahib, Seyla, "Democracy and Difference: Reflections on the Metapolitics of Lyotard and Demda," Journal of Political Philosophy 2, no. 1 (1994): 1-23.

Blum, A. Lawrence, “Recognition, Value, and Equality: A Critique of Charles Taylor's and Nancy Fraser's Accounts of Multiculturalism," Constellations 5, no.1 (March 1980): 73 99.

Stephen G. Brooks and William C. Wohlforth, "American Primacy in Perspective," Foreign Affairs 81, no. 4 (2002): 20-33.

Brown, Chris, "Tragedy, 'Tragic Choices' and Contemporary International Political Theory," International Relations 21, no. 1 (2007): 5-13. 
-, "The House that Chuck Built: Twenty-Five Years of Reading Charles Beitz," Review of International Studies 31 (2005): 273-74

-, "The Construction of a 'Realistic Utopia': John Rawls and International Theory," Review of International Studies 28, no. 1 (2002): 5-21.

-, "Cultural Diversity and International Political Theory: From the Requirement to "Mutual Respect?" Review of International Studies 26 (2000): 199-213.

-, "Turtles all the Way down: Foundationalism, Critical Theory and International Relations," Millennium Journal of International Studies 23, no. 2 (June 1994): 213-36.

-, "International Engagements: The Politics of North American International Relations Theory," Political Theory 29, no. 3 (June 2001): 432-48.

-, "Patterns of Dissent and Celebration of Difference: Critical Social Theory and International Relations," International Studies Quarterly 34 (1999): 269-93.

-, "The Politics of Radical Interdependence: A Rejoinder to Daniel Warner," Millennium: Journal of International Studies 25, no. 1 (1996): 129-141.

-, "Political Excess and the Limits of Imagination," Millennium: Journal of International Studies 23, no. 2 (June 1994): 365-75.

Chan, Steve, "On Different Types of International Scholarship," Journal of Peace Research 39 , no. 6 (2002): 747-56.

Connolly, Williams, "Taylor, Foucault, and Otherness" Political Theory 13, no. 3 (August 1985): 365-376.

Cooke, Maeve, "Authenticity and Autonomy: Taylor, Habermas and the Politics of Recognition," Political Theory 25, no. 2 (April 1997): 258-88.

-, "Realizing the Post-Conventional Self," Philosophy and Social Criticism, 20, no. 112 (1994): 87-101.

Cox, Robert, "Social Forces, States and World Order: Beyond International Relations," Millennium: Journal of International Affairs 10, no. 2 (June 1981): 126-55.

-, "Gramsci, Hegemony, and International Relations: An Essay in Method," Millennium: Journal of International Studies 12, no. 2(June 1983):162-75.

-, "Gramsci, Hegemony, and International Relations: An Essay in Method," Millennium: Journal of International Studies 12, no. 2 (June 1983): 162-75. 
Dallmayr, Fred, "Globalization from Below," International Politics 36, no. 3 (September 1999): 321-324.

Devetak, Richard, "The Project of Modernity and International Relations Theory," Millennium Journal of International Studies 24, no. 1 (Spring 1995): 27-49.

-, "Justice Unbound? Globalization, States and Transformation of the Social Bond," International Affairs 75, no. 3 (July 1999): 483-498.

Doty, Roxanne, "Desires all the Way Down," Review of International Studies 26, no. 1 (2000): 137-39.

Elshtain, Jean Bethke, "Really Existing Communities," Review of International Studies 25, issue 1 (January 1999): 141-46.

Evans, Tony and Ayers, Allison, "In the Service of Power: The Global Political Economy of Citizenship and Human Rights," Citizenship Studies 10, no. 3 (July 2006): 289-308.

-, "International Human Rights Law as Power/Knowledge," Human Rights Quarterly 27, no. 3 (August 2005): 1046-1068.

Frankenberg, Richard and L. Mani, "Cross-Currents, Cross-Talks," Cultural Studies 7 (1993): 292-309.

Fraser, Nancy, "Reframing Justice in a Globalizing World," New Left Review 36 (November-December 2005): 69-88.

-, "Recognition without Ethics?" Theory, Culture and Society 18, no. 2-3 (2001): 21-42.

-, "Rethinking Recognition," New Left Review 3 (May-June 2000): 107-120.

-, "From Redistribution to Recognition? Dilemmas of Justice in a 'Post-Socialist' Age," New Left Review 212 (July/August 1995): 68-93.

Frost, Mervyn, "Tragedy, Ethics and International Relations," International Relations17, no. 4 (2003): 477-95.

George, Jim George and Campbell, David, "Patterns of Dissent and Celebration of Difference," International Studies Quarterly 34 (1999): 269-93.

Germy J. Philip, "Paradoxes of the Competition State: The Dynamics of Political Globalization," Government and Opposition 32, no. 2, (Spring 1997): 270-71.

Gill, Stephan, "Globalization, Market Civilization, and Disciplinary Neo-Liberalism," in Millennium Journal of International Affairs, 24, no. 3 (1995): 399-423. 
Guzzini, Stefano, "A Reconstruction of Constructivism in International Relations," European Journal of International Relations 6, no. 2 (2000):147-82.

Habermas, Jürgen, "Why Europe Needs a Constitution," New Left Review no. 11 (September-October 2001): 5-26.

-, "The European Nation-State and the Pressures of Globalization," New Left Review, no. 235 (1999): 46-59.

Hoffman, Mark, "Critical Theory and the Inter-Paradigm Debate," Millennium: Journal of International Studies 16, no. 2 (June 1987): 231-49.

Honneth, Axel, "Recognition or Redistribution? Changing Perspectives on the Moral Order of Society," Theory, Culture and Society 18, no. 2-3 (2001): 43-55.

-, "Integrity and Disrespect: Principles of a Conception of Morality Based on Theory of Recognition," Political Theory 20, no. 2, (May 1992): 187-201.

Hoover, Jeffrey, "Do the Politics of Difference Need to be Freed of Liberalism," Constellations 8, no. 2 (June 2001): 201-218.

Hunter, Allan, "Globalization from Below: Promises and Perils of the New Internationalism," Social Policy 25, no. 4 (Summer 1995): 6-13.

Hurd, Ian, "Legitimacy and Authority in International Politics," International Organization 53, issue 2 (Spring 1999): 379-408.

Jabri, Vivienne, "Restyling the Subject of Responsibility in International Relations," Millennium Journal of International Studies 27, no. 3 (1998): 591-611.

Kenan, Malik, "Universalism and Difference in Discourses of Race," Review of International Studies 26, no. 5 (December 2000): 155-177.

Kiely, Ray, "United States Hegemony and Globalization: What Role for Theories of Imperialism?" Cambridge Review of International Affairs 19, no. 2 (June 2006): 205-21.

Kieh, George Klay, Africa and New Globalization (Berlington, VT.: Ashgate, 2008).

-, "The Last Refuge of Noble Savage? A Critical Assessment of Post-Development Theory," European Journal of Development Research 11, no. 1 (June 1999): 34-38.

Kolosko, George, "Political Obligation and the Natural Duties of Justice," Philosophy and Public Affairs 23 (1994): 251-70. 
Levomaki, Irma, "On Charles Taylor and the Challenge of Modernity," Acta Philosophica Fennica 71 (2002): 133-147.

Levy, Neil, “Charles Taylor on Overcoming Incommensurability" Philosophy and Social Criticism 26, no. 5 (2000): 47-61.

Andrew Linklater, "The Evolving Spheres of International Justice," International Affairs 75, no. 43 (1999): 473-482.

-, "The Question of Next Stage in International Relations Theory: A Critical-Theoretical Point of View," Millennium Journal of International Studies 21, no. 1 (March 1992): 77-98.

-, "Men and Citizens in International Relations," Review of International Studies 7 (1991): 23-37.

Lipschuta D. Ronnie, "Reconstructing World Politics: The Emergence of a Global Civil Society," Millennium: Journal of International Studies 21, no. 3 (December 1992): 389420 .

Marchand, Marianne, "Different Communities/ / Different Realities / Different Encounters: A Reply to J. Ann Tickner," International Studies Quarterly 42, no. 1 (March 1998): pp. 199-204.

Min K. Anselm, "From Difference to the Solidarity of the Others," Philosophy and Social Criticism 31, no. 7, (2005): 823-49.

Morrice, David, "The Liberal-Communitarian Debates in Contemporary Political Philosophy and its Significance for International Relations," Review of International Studies 26 (2000): 233-51.

Oliver, Kelly, "Beyond Recognition: Witnessing Ethics," Philosophy Today 44, no.1 (Spring 2000): 31-43.

O'Niell John, "Oh, My Others, There is no Other," Theory, Culture and Society 18, no. 2-3 (2001): 77-99

Pogge, Thomas, "Priorities of Global Justice," Metaphilosophy 32, no. 1-2 (January 2001): 6-24.

-, "Rawls on International Justice," The Philosophical Quarterly 51, no. 203 (April 2001): 246-53.

-, "The International Significance of Human Rights," The Journal of Ethics 4 (2000): 45-69. 
-, "An Institutional Approach to Humanitarian Intervention," Public Affairs Quarterly 6, no.1 (1992): 89-103.

Presbey M. Gail, "The Struggle for Recognition in the Philosophy of Axel Honneth, Applied to the Current South African Situation and its Call for an African Renaissance," Philosophy and Social Criticism 29, no. 5 (2003): 537-61.

Reidy, David, "Rawls on International Justice: A Defense," Political Theory 32, no. 3 (June 2004): 291-319.

Rengger, Nicholas, "Tragedy or Scepticism? Defending the Anti-Pelagian Mind in World Politics," International Relations, 19, no. 3 (2005): pp. 321-8.

-, "Political Theory and International Relations: Promised Land or Exit from Eden," International Affairs 46, no. 4 (2000): 755-70.

Risse-Kappen, Thomas, "Let's Argue! Communicative Action in World Politics," International Organizations 54, no. 1 (2000): 1-39.

Robinson, Fiona, "Globalizing Care: Ethics, Feminist Theory, and the International Relations," Alternatives: Social Transformation and Humane Governance 22, no.1 (1997): 122-23.

Rosen, Michael, "Must We Return to Moral Realism?" Inquiry 34 (June 1991): 183-194.

-, "New Dimensions of Security: The Interaction of Globalizing and

Localizing Dynamics," Security Dialogue 25, no. 3 (September 1994): 255-81.

Rosenau, Pauline, "Once again into the Fray: International Relations Confronts the Humanity," Millennium Journal of International Studies 19, no. 1 (March 1990): 83-110.

Rushton, Simon, "The UN Secretary-General and Norm Entrepreneurship: Boutros Boutros-Ghali and Democracy Promotion," Global Governance: A Review of Multilateralism and International Organizations 14, issue 1 (January-March 2008): 95-110.

Scholte J. Aart, "The Geography of Collective Identities in a Global Age," Review of International Political Economy 3, no. 4 (Winter 1990): 577-593.

Schuster, Anke, "Does Liberalism Need Multiculturalism? A Critique of Liberal Multiculturalism", Essays in Philosophy 7, no.1 (2006).

Scott, Thomas, "Thinking Religious Cultural Pluralism Seriously; The Global Resurgence of Religion and the Transformation of International Society," Millennium: Journal of International Studies 29, no. 3 (2000): 815-841. 
Shapcott, Richard, "Cosmopolitan Conversations: Justice, Dialogue and the Cosmopolitan Project," Global Society 16, no. 3 (2002): 221-43.

Smith, Nick, "Charles Taylor, Strong Hermeneutics and the Politics of Difference," Radical Philosophy 68 (Autumn 1994): 19-27.

Spencer, Vicki, "Toward an Ontology of Holistic Individualism: Herder's Theory of Identity, Culture and Community," History of European Ideas 22, issue. 3 (May 1996): 245-60.

Swanson, Jacinda, "Recognition and Redistribution, Rethinking Cultural and the Economic," Theory, Culture, and Society 22, no. 4 (2005): 87-118.

Sypnowich, Christine, "Some Disquiets about Difference," Praxis International 13, no. 2 (July 1993): 81-93.

Taylor, Charles, "Comments of Jürgen Habermas's From Kant to Hegel and Back Again," European Journal of Philosophy 7, no. 2 (1999): 158-63.

-, "Globalization and the Future of Canada," Queen's Quarterly 105, no. 3 (1998): 331-42.

-, "The Dynamics of Democratic Exclusion," Journal of Democracy 9, no. 4 (1998): 14356.

-, "Can Liberalism be Communitarian?" Critical Review: An Interdisciplinary Journal of Politics and Society 8, no.2 (Spring 1994): 257-262.

-, "Reply to Commentators," Philosophy and Phenomenological Research 54, no. 1 (March 1994): 203-213.

—, "Connolly, Foucault and Truth," Political Theory 13 (1985): 377-85.

Thomson, Simon, "Is Redistribution a Form of Recognition? Comments on the FraserHonneth Debate," Critical Review of International Social and Political Philosophy 8, no. 1 (March 2005): 85-102.

Zurn F. Christopher, "Identity or Statues: Struggles over Recognition in Fraser, Honneth, and Taylor," Constellations 10, no. 4 (2003): 519-537. 